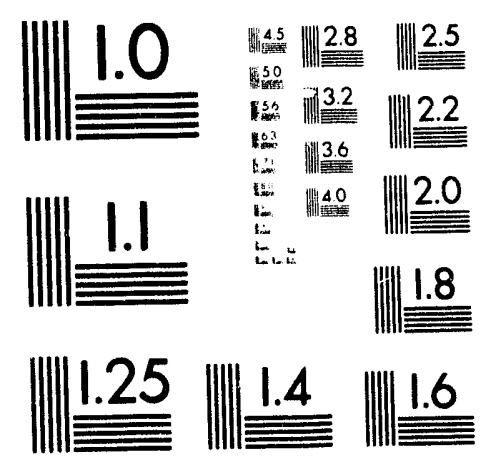



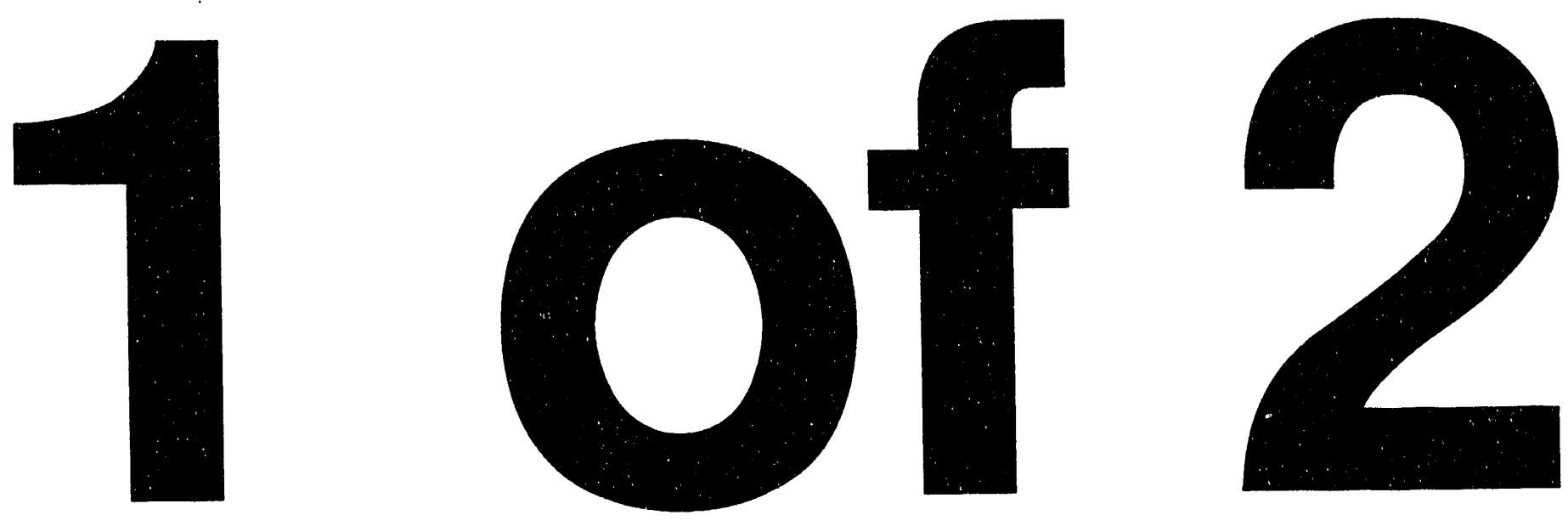
WHC-EP-0666

UC- 630

\section{Groundwater Impact Assessment Report for the 100-D Ponds}

D. J. Alexander

Date Published

July 1993

Prepared for the U.S. Department of Energy Office of Environmental Restoration and Waste Management

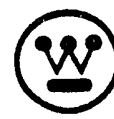

Westinghouse Hanford Company 
WHC-EP-0666

APPROVAL PAGE

DOCUMENT TITLE: GROUNDWATER IMPACT ASSESSMENT REPORT FOR THE 100-D PONDS

Prepared by: $\frac{\text { D.2. Alefande? }}{\begin{array}{l}\text { D. J.Alexander } \\ \text { Geosciences Function } \\ \text { Environmental Division }\end{array}} \frac{7-27-93}{\text { Date }}$

Technical

Review by:
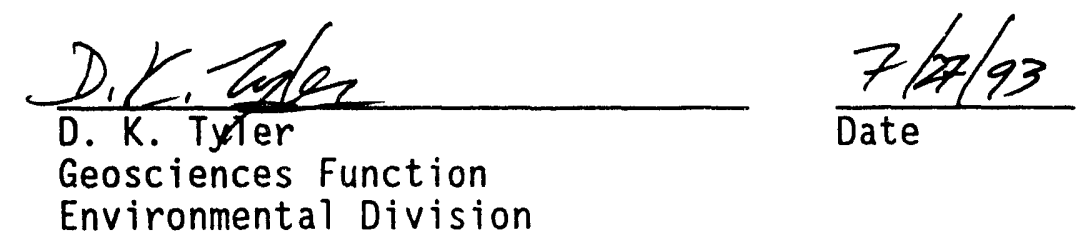

Environmental Division

Approved by:
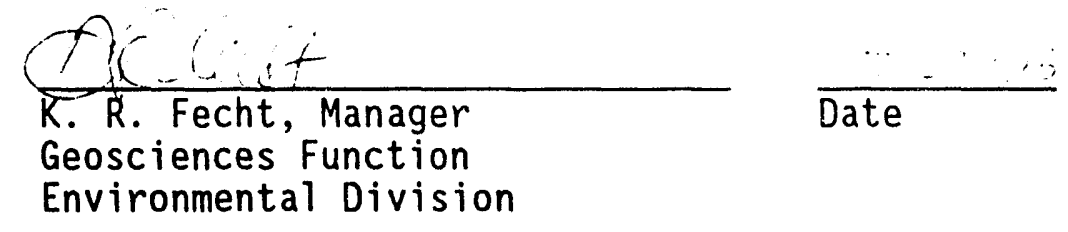

Environmental Division

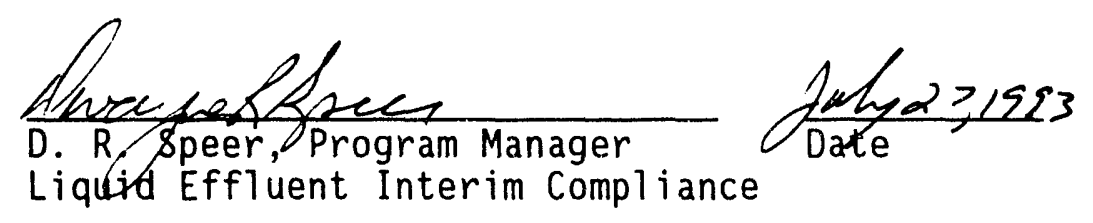




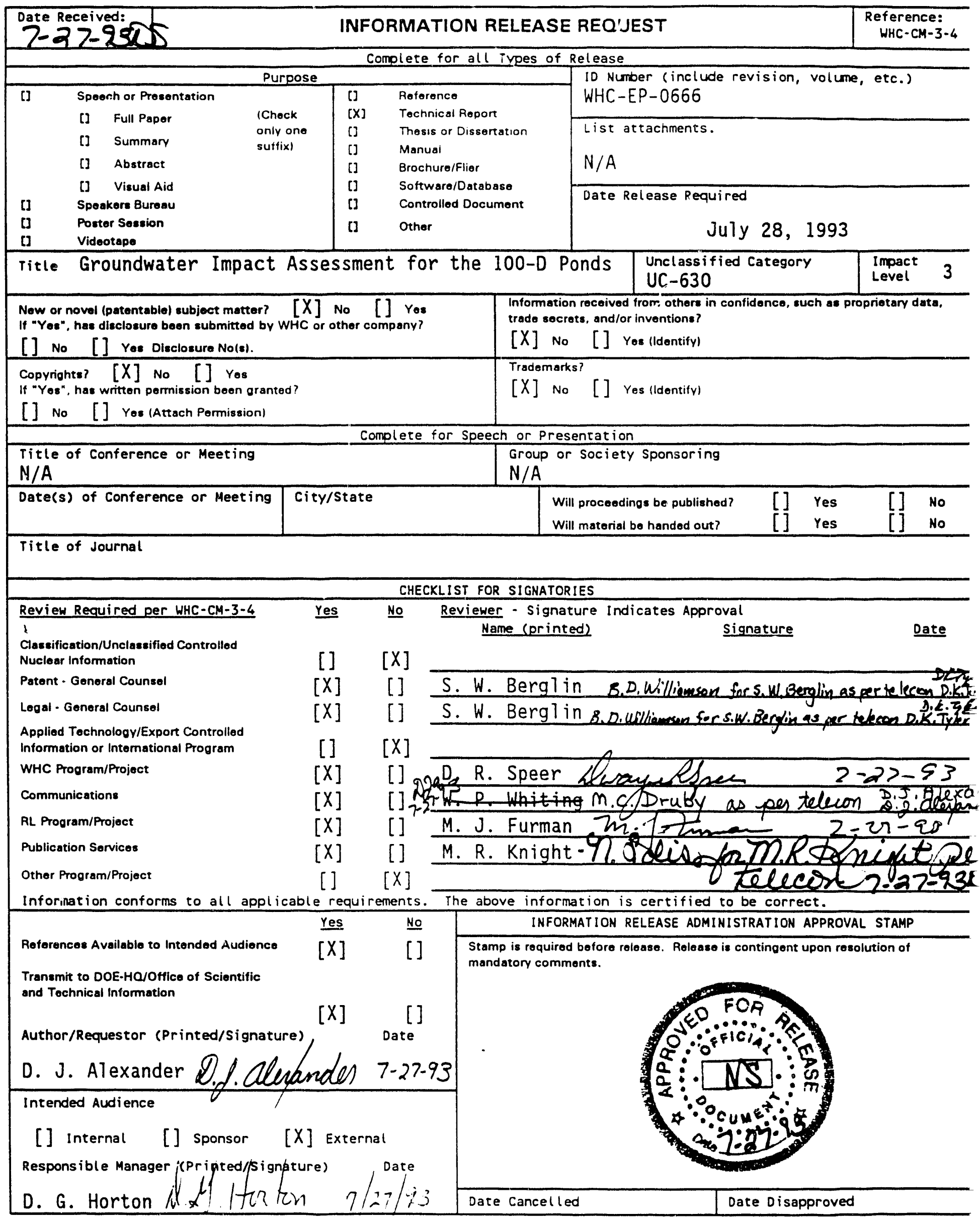




\section{EXECUTIVE SUMMARY}

The 183-D Water Treatment Facility (WTF) discharges effluent to the 120-D-1 Ponds (100-D Ponds) located north of the 100-D Area perimeter fence. This report satisfies one of the requirements of the Hanford Federal Facility Agreement and Consent Order (Tri-Party Agreement) Milestone M-17-00B as agreed by the U.S. Department of Energy, Washington State Department of Ecology, and the U.S. Environmental Protection Agency. Tri-Party Agreement Milestone $M-17-0 O B$ includes a requirement to assess impacts to groundwater from disposal of the 183-D WTF effluent to the 100-D Ponds. In addition, the 100-D Ponds are a Resource Conservation and Recovery Act of 1976 treatment, storage, and disposal facility covered by the 100-D Ponds Closure Plan (DOE-RL 1993a).

There is evidence of groundwater contamination, primarily nitrate, tritium, and chromium, in the unconfined aquifer beneath the 100-D Area and 100 Areas in general. The contaminant plumes are area wide and are a result of past-practice reactor and disposal operations in the 100-D Area currently being investigated as part of the 100-DR-1 and 100-HR-3 Operable Units (DOE-RL 1992b, 1992a).

The 100-D Ponds are constructed in a former coal ash disposal basin. In these sediments, solid metal hydroxides formed and continue to dissociate, thus increasing the $\mathrm{pH}$ of the groundwater in the vicinity of the ponds in relation to the rest of the 100-D Area. Mobile metal oxyanions are rapidly flushed from the system. Less mobile metals form metal-hydroxy silicates, carbonates, and hydroxides and are retained on the soil columin.

Based on current effluent conditions, continued operation of the 100-D Ponds will not adversely affect the groundwater quality in the 100-D Area. Monitoring wells near the pond have slightly higher alkaline pH values than wells in the rest of the area. Concentrations of known contaminants in these wells are lower than ambient 100-D Area groundwater conditions and exhibit a localized dilution effect associated with discharqes to the pond. Hydraulic impact to the local groundwater system from these discharges is minor. The groundwater monitoring well network for the 100-D Ponds is adequate. 
WHC-EP-0666 
WHC-EP-0666

\section{CONTENTS}

1.0 INTRODUCTION . . . . . . . . . . . . . . . . . . . . . . . . . $1-1$

1.1 BACKGROUND . . . . . . . . . . . . . . . . . . . . . . . $1-1$

1.2 METHODOLOGY . . . . . . . . . . . . . . . . . . . 1-1

2.0 100-D AREA FACILITIES DESCRIPTION . . . . . . . . . . . . . . 2-1

2.1 LOCATION . . . . . . . . . . . . . . . . . . . . . . . 2-1

2.2 HISTORY . . . . . . . . . . . . . . . . . . . . . . . 2-1

2.3 FACILITIES . . . . . . . . . . . . . . . . . . . . . . 2-1

2.3.1 100-D Ponds . . . . . . . . . . . . . . . . . . . . 2-1

2.3.2 188-D [Coal] Ash Disposal Basin . . . . . . . . . . 2-2

2.3.3 183-D Water Treatment Facility (183-D WTF) . . . . . 2-3

2.3.4 182-D Reservoir ................ 2-3

2.3.5 189-D Mechanical Development Laboratory (189-D MDL) . . 2-3

$3.0100-D$ PONDS EFFLUENT CHARACTERISTICS . . . . . . . . . . . . . . 3-1

3.1 SOURCES . . . . . . . . . . . . . . . . . . . . . 3-1

3.1.1 Past-Practice Sources . . . . . . . . . . . . . 3-1

3.1.2 Present Sources . . . . . . . . . . . . . . . . 3-1

3.2 SYSTEM CONFIGURATION AND OPERATION . . . . . . . . . . . . . . . $3-2$

3.2.1 Past-Practice Sources . . . . . . . . . . . . . . 3-2

3.2.2 Present Sources . . . . . . . . . . . . . . . 3-2

3.3 DISCHARGE VOLUME AND FLOW REGIME . . . . . . . . . . . . 3-3

3.3.1 Past-Practice Sources . . . . . . . . . . . . . . 3-3

3.3.2 Present Sources . . . . . . . . . . . . . 3-3

3.4 EFFLUENT CONSTITUENTS . . . . . . . . . . . . . . . . . . . . $3-3$

3.4.1 Quantities................ 3-3

3.4.2 Loading Rates ... . . . . . . . . . . . . . . 3-4

3.4.3 Operational Factors . . . . . . . . . . . . . . 3-6

3.5 CONSTITUENTS OF INTEREST AND KEY PARAMETERS . . . . . . . . . . . $3-7$

\begin{tabular}{l}
4.0 CONCEPTUAL MODEL OF HYDROLOGIC RESPONSE AND \\
CONTAMINANT MIGRATION... \\
\hline
\end{tabular}

4.1 HYDROGEOLOGIC FRAMEWORK . . . . . . . . . . . . . . . . . . . 4-1

4.1.1 Regional and Hanford Site Geology . . . . . . . . . . 4-1

4.1.2 100-D Area Geology . . . . . . . . . . . . . . . . 4-3

4.1.3 Regional and Hanford Site Hydrology . . . . . . . . . 4-5

4.1.4 100-D Area Hydrology . . . . . . . . . . . . . . 4-9

4.2 HYDROLOGIC RESPONSES TO EFFLUENT DISPOSAL . . . . . . . . . . 4-10

4.3 GROUNDWATER QUALITY .................... . . 4-11

4.4 SOIL COLUMN CHEMICAL FACTORS . . . . . . . . . . . . . . . . . . . 4-17

4.5 SUMMARY OF CONCEPTUAL MODEL OF MOISTURE MOVEMENT AND
CONTAMINANT TRANSPORT . . . . . . . . . . . . . . . . . . . $4-17$

5.0 IMPACT ASSESSMENT ...................... . . . 5-1

5.1 HYDROLOGIC IMPACTS . . . . . . . . . . . . . . . . . . 5-1

5.2 CONTAMINANT IMPACTS ... . . . . . . . . . . . . . . . . . . . . . . . . . . 5-1

5.2.1 One-Dimensional Flow and Transport
Analysis (Analytical Methods) .......... . 5-1

5.2.2 Results of Initial Analytical Solution . . . . . . . 5-3

5.2.3 Results of Revised Analytical Solution....... . 5-3 
WHC-EP-0666

\section{CONTENTS (Continued)}

5.4 EVALUATION OF MONITORING NETWORK ADEQUACY . . . . . . . . . . . . 5-4

5.4.1 Groundwater Monitoring Well Placement . . . . . . . . 5-4

5.4.2 Reporting of Monitoring Data........... . 5-5

6.0 SUMMARY AND CONCLUSIONS ..................... . . . . . .

7.0 REFERENCES . . . . . . . . . . . . . . . . . . . . . . . 7-1 


\section{FIGURES}

2-1 Location of the 100-D Area on the Hanford Site . . . . . . . . . 2-5

2-2 Location of the 100-D Ponds in the 1nO-D Area . . . . . . . . . . . 2-6

2-3 Plan View of the 100-D Ponds . . . . . . . . . . . . . . . . . 2-7

3-1 The 183-D Water Treatment Facility (WTF) . . . . . . . . . . . . . 3-9

3-2 Flow Schematic of the 100-D Water Treatment Facilities . . . . . 3-10

4-1 Generalized Stratigraphy of the Pasco Basin and Surrounding Area . 4-21

4-2 Generalized Stratigraphy of the Suprabasalt Sediments in the Pasco Basin ............. . . 4-22

4-3 Generalized Stratigraphy of the Miocene-Pliocene Ringoid Formation in the Pasco Basin .. . . . . . . . . . . . . . . . . . . 4-23

4-4 Generalized Hydrologic Setting of the 100-D Area . . . . . . . . . 4-24

4-5 Cross-Section of the Vadose Zone and Uppermost Aquifer Beneath the 100-D Ponds....... . . . . . . . . . . 4-25

4-6 Hydrologic Basins Designated for the Washington State Portion of the Columbia Plateau . . . . . . . . . . . . . . . . 4-26

4-7 Location of Water Disposal Ponds on the Hanford Site . . . . . . 4-27

4-8 Hindcast Water Table Map of the Hanford Site, January 1944 . . . . 4-28

4-9 Hanford Site Water Table Map, June 1989 . . . . . . . . . . . . . . 4-29

4-10 Water Table in the 100-D Area and Vicinity, June 1992..... . . 4-30

4-11 Water Table in the 100-D Area and Vicinity, October 1992 . . . . . 4-31

4-12 Water Table in the 100-D Area and Vicinity, January 1993 . . . . . 4-32

4-13 Distribution of Tritium in Groundwater in the 100-D Area . . . . . 4-33

4-14 Distribution of Chromium in Groundwater in the 100-D Area . . . . 4-34

4-15 Distribution of Nitrate in Groundwater in the 100-D Area . . . . . 4-35

4-16 (a) pH vs. Time and (b) Specific Conductance in Upgradient Well 199-D5-13 and Downgradient Wells 1990-D8-4, -5, and -6... . 4-36

4-17 Distribution of Specific Conductance in Groundwater in the 100-D Area . . . . . . . . . . . . . . . . 4-37

4-18 100-D/DR Area--Selected Waste Disposal Facilities and Monitoring Wells . . . . . . . . . . . . . . . . . . . 44-38

4-19 Illustrated Conceptual Model for the 100-D Ponds . . . . . . . . . 4-39

4-20 Elementary Reactions and Reaction Products for Cadmium in an Alkaline Carbonate System . . . . . . . . . . . . . . . . . 4-40

5-1 Lithology of Well 199-D8-3 Near 100-D Ponds... . . . . . . . . . 5-7

5-2 Hydraulic Conductivity Versus Moisture Content . . . . . . . . . . 5-8

5-3 Groundwater Monitoring Wells in and Near the 100-D Area.... . . 5-9 


\section{TABLES}

3-1 Past and Present Effluent Stream Sources and Amounts

Discharged to the 100-D Ponds . . . . . . . . . . . . . . . . 3-11

3-2 Radionuclide and Chemical Loading, 183-D Filter Backflush

Wastewater . . . . . . . . . . . . . . . . . . . 3-12

3-3 Maximum Potential Inventory of Dangerous Waste to 100-D Ponds . . . 3-13

3-4 200 Area Coal Ash Slurry Leachate Analysis Results . . . . . . . . 3-14

3-5 Analytical Results for Coal and Coal Ash Leachate Samples . . . . 3-15

3-6 Summary of Toxic Characteristic Leach Procedure Metals and $\mathrm{pH}$ Analytical Results for Fly and Bottom Ash Leachate Mixtures 3-16

3-7 183-D Filter Backwash Wastewater Summary . . . . . . . . . . . . . 3-17

4-1 Hydraul ic Parameters for Various Areas at the Hanford Site . . . 4-41

4-2 Hanford Site Maxima and Average Concentrations (ppm) for Unconfined Aquifers, Springs, and Confined Aquifers . . . . . . 4-42

4-3 Groundwater Quality Indicator Monitoring Results . . . . . . . . . 4-44

4-4 Cation Monitoring Results . . . . . . . . . . . . . . . . . . 4-46

4-5 Anion Monitoring Results . . . . . . . . . . . . . . . . . . . 4-47

4-6 Metal Monitoring Results (Unfiltered).............. . 4-49

4-7 Radionuclide Monitoring Results . . . . . . . . . . . . . . . . . . 4-54

5-1 Effluent Stream Sampling Data, 183-D Filter Backflush . . . . . . . 5-10

5-2 Initial Analytical Solution Results for the 100-D Ponds.... . . 5-11

5-3 Revised Analytical Solution Results for the 100-D Ponds..... . . 5-12

5-4 Wells Monitored for Chemistry or Water Levels for the 100-D Ponds . 5-13 


\subsection{INTRODUCTION}

Groundwater impact assessments are required for a number of liquid effluent receiving sites according to the Hanford Federal Facility Agreement and Consent Order (Tri-Party Agreement) Milestones M-17-00A and $M-17-00 B$, as agreed by the U.S. Department of Energy (DOE), Washington State Department of Ecology (Ecology), and the U.S. Environmental Protection Agency (EPA), (Ecology et al. 1991). This report assesses the impacts to groundwater from the disposal of past and present effluent from various 100-D Area facilities to the 120-D-1 Ponds (100-D Ponds).

\subsection{BACKGROUND}

In response to public comments on the original Tri-Party Agreement and at the request of the signatories on the Tri-Party Agreement, the DOE Richland Operations office (RL) conducted a study to assess the impact of liquid effluents discharged to the ground at the Hanford Site (WHC 1990a, 1990b). The EPA and Ecology expressed several concerns regarding uncertainties in the evaluations made by RL. Foremost among these concerns were the lack of sitespecific data, the need to consider interactions with adjacent liquid discharge facilities, and the need for more rigorous models of contaminant transport. As a result of these concerns, the RL, Ecology, and EPA (the three parties) created a series of Tri-Part Agreement Milestones, including $M-17-00 A, M-17-00 B, M-17-13$, and M-17-13A, which pertain to groundwater impact assessments.

Tri-Party Agreement Milestones M-17-00A and M-17-00B require impact assessments for Phase I and II waste streams. Phase I and II waste streams are defined in Stordeur and Flyckt (1988). The 100-D Ponds were defined as a Phase II waste stream. Tri-Party Agreement Milestone M-17-13 required the development of a methodology for assessing the impact of liquid effluent discharge on groundwater, which resulted in the document $A$ Methodology for Assessing Impacts to Groundwater from Disposal of Liquid Effluent to ine Soil at the Hanford Site (Tyler 1991). Thirty days after regulatory approval of the methodology document, as required by Tri-Party Agreement Milestone M-17-13A, a schedule for performing assessments at 13 receiving sites was completed. The 100-D Ponds are identified to undergo assessment to support the 216 Permit application process (Tyler 1991). Sampling of the effluent for characterization required for the 216 Permit application occurred in June 1993. Results of this sampling are not yet available.

\subsection{METHODOLOGY}

The previously mentioned methodology document (Tyler 1991) was followed in preparing the groundwater impact assessment for the 100-D Ponds. Included in that document is the categorization of each of the 13 receiving sites into 1 of 3 levels, based on the amount of effort needed to perform the assessment. A level 1 receiving site groundwater impact assessment relies on available information. A groundwuter impact assessment of a level 2 receiving site may require nonintrusive field work to verify the extent of existing contamination. A level 3 site may require intrusive field work. If through the course of performing a level 1 impact assessment, it is discovered that 
existing information is inadequate, the assessment may be raised to a level 2 or 3 .

The methodology document outlines several tasks to be conducted as part of the groundwater impact assessment for level 1 receiving sites:

- Prepare and present a plan describing how the groundwater assessment will be conducted

- Characterize the liquid effluent stream

- Evaluaie the site-specific hydrogeology

- Develop a site conceptual model

- Assess the hydrologic impact of the 1iquid effluent stream

- Assess the contaminant impact of the liquid effluent stream

- Evaluate the adequacy of the existing monitoring well network

- Prepare a written report of the results.

The tasks required for level 2 and 3 receiving sites include those outlined above (with minor differences) and include field work related activities, as follows:

- Organize and plan facility-specific assessment (same as level 1 tasks)

- Characterize effluent using existing data (same as level 1 tasks)

- Develop a preliminary site conceptual model--aids in identification of information necessary to refine the conceptual model and support assessment techniques that may have more rigorous data requirements

- Identify additional information needs and plan data collection-may include collection of field data and laboratory analyses (water chemistry sampling, shallow soil samples, remote sensing, geophysical surveys, water level measurements, and physical and chemical analyses of archived soil samples)

- Level 3 data collection may also include borehole drilling and sampling, monitoring well construction (Resource Conservation and Recovery Act of 1976 [RCRA] standard), aquifer testing, and more extensive data collection for activities listed in the previous bullet

- Collect field data

- Analyze and interpret data to refine conceptual model 
- Assess groundwater impacts and identify additional information needs

- Prepare a written report of the results.

In the methodology report, the 100-D Ponds were categorized as a leve 3 receiving site on the basis of a lack of groundwater data for characterization purposes. New monitoring wells were installed at this site to characterize the groundwater in support of permitting the ponds as a RCRA treatment, storage, and disposal (TSD) facility (Hartman 1992). In addition, this site is part of the 10n-HR-3 Groundwater Operable Unit and the 100-DR-1 Source Operable Unit, which are controlled by the RCRA Facility Investigation/ Coirective lieasures Study Work Plans (DOE-RL 1992a, 1992b). This impact assessment incorporated data collected under the RCRA-TSD program and RCRA Corrective Measures Study Work Plans.

Several key assumptions inherent to all groundwater impact assessments are explained in the methodology document and warrant summarizing here. For this impact assessment, the following assumptions are relevant.

- The expected level of impact from the use of the receiving site determines how well the chemistry, geology, and hydrology need to be understood.

- Modeling sophistication is tailored to available information and the expected level of impact to the receiving site.

- New site-specific geologic, hydrologic, and groundwater data obtained through dri i ing require 1.5 to 2 years to acquire.

- Data collection and modeling activities are integrated with other Tri-Party Agreement milestones.

- Existing data are treated as fully validated. 
WHC-EP-0666

1-4 
WHC-EP-0666

\subsection{0-D AREA FACILITIES DESCRIPTION}

\subsection{LOCATION}

The Hanford Site is a $560-\mathrm{mi}^{2}\left(1,450-\mathrm{km}^{2}\right)$ tract of 1 and located in Benton, Franklin, and Grant Counties in the south-central portion of Washington State. The 100-D Area is located along the south shore of the Columbia River in the northern part of the Hanford Site, approximately $46 \mathrm{mi}(74 \mathrm{~km})$ north of the city of Richland (Figure 2-1). The 100-D Ponds are located immediately north of the 100-D Area perimeter fence (Figure 2-2).

\subsection{HISTORY}

In 1943 the Hanford Site was chosen as a location for the Manhattan Project to produce pluton ium for use in nuclear weapons. The 100-D Area at Hanford was used from 1944 to 1967 for plutonium production reactors and related operational support facilities. These operations resulted in the release of chemical and radioactive wastes into the area soil, air, and water. The 100-D Ponds facility began disposal of wastewater in 1977 and continues operations today (DOE-RL 1993a).

\subsection{FACILITIES}

The 100-D Ponds currently receive only nonregulated effluent from the 183-D Water Treatment Facility by way of the process sewer system. However, in the past other facilities discharged regulated wastewater to the ponds by way of the same process sewer system. In addition, the ponds were constructed within the boundaries of what was the 188-D (Coal) Ash Disposal Basin, and the coal ash may be contributing contaminants to the ponds (DOE-RL 1993a).

\subsubsection{0-D Ponds}

The 100-D Ponds consist of two interconnected surface ponds for disposal of nonradioactive, nondangerous liquid effluent from the 183-D Water Treatment Facility. The 100-D Ponds began operation in 1977 as a single, uncovered and unl ined pond approximately 0.5 acre ( 0.2 hectare) in size. The original pond was constructed by excavating an area in the eastern half of what was originally the 188-D Ash Disposal Basin to a depth of $30 \mathrm{ft}(9 \mathrm{~m})$. The pond level was established at an elevation approximately $18 \mathrm{ft}(6 \mathrm{~m})$ below that of the 100-D Area. In 1979, the original pond design was modified to eliminate a bottom sealing problem caused by the accumulation of flocculent. Construction of an east-west dike separated the pond into two north-south aligned ponds (Figure 2-3). The ponds have a combined surface dimension of 160 by $220 \mathrm{ft}$ ( 50 by $67 \mathrm{~m}$ ) and the original surface elevation of the first pond was maintained (DOE-RL 1993a).

The south pond has dimensions of $95 \mathrm{ft}$ in length by $120 \mathrm{ft}$ in width by $12 \mathrm{ft}$ in depth (24 by 49 by $4 \mathrm{~m}$ ), a design capacity of $400,000 \mathrm{gal}$

( 1.5 million $L$ ), and functions as a settling pond (see Figure 2-3). Presently it is half-full of standing water and sediment. The sediment depth varies from 1 to $5 \mathrm{ft}(0.3$ to $1.5 \mathrm{~m})$ within the pond. There is mininimal aquatic 
vegetation in the pond. On occasion there is floating brown biologic material on the water surface, and several types of wind-blown vegetation can be found floating in the pond at a given time (e.g., tumbleweeds). Tall grasses and cattails grow along the edges of the pond. At this time, the pond is not designated as a wetlands area (DOE-RL 1993a).

The north pond has dimensions of $105 \mathrm{ft}$ in length by $160 \mathrm{ft}$ in width $b_{j}$ $18 \mathrm{ft}$ in depth ( 32 by 49 by $6 \mathrm{~m}$ ), a design capacity of $570,000 \mathrm{gal}$ ( 2 million $L$ ), and functions as a percolation pond (see Figure 2-3). Currently the pond is dry, but it occasionally has received a small amount of water from the settling pond. During January 1993, the valve between the ponds was open and there was small but constant flow into the north pond. Personnel in charge of the pond discovered the open valve and turned it off; the valve between the two ponds is supposed to be closed. The pond has very sparse grass and brush and an accumulation of tumbleweeds. The pond contains no aquatic vegetation, which indicates the absence of water in the near past (DOE-RL 1993a).

Two horizontal effluent transfer pipes placed within the dike connect the two ponds (see Figure 2-3). The upper pipe is $6 \mathrm{in} .(15 \mathrm{~cm})$ in diameter and located $1 \mathrm{ft}(0.3 \mathrm{~m})$ below the top of the dike. The second pipe is 8 in. $(20 \mathrm{~cm})$ in diameter and enters the north pond at a depth of $12 \mathrm{ft}(4 \mathrm{~m})$ below the top of the pond. The pipe outflow into the north pond is approximately $6 \mathrm{ft}(2 \mathrm{~m})$ below the current level of water in the south pond (DOE-RL 1993a).

A carbon steel weir is located in the northeast portion of the south pond (see Figure 2-3). The exact design of the weir is unknown, and only a small portion of it is visible above the water level. This portion is a 2-ft(0.6-m-) diameter metal pipe with a removable 1id. A valve control arm sticks out of the dike directly above the discharge pipe and likely operates the control valve between the two ponds. The weir is most likely a crude filtration system between the settling and percolation ponds (DOE-RL 1993a).

The 100-D Ponds are surrounded on the east, north, and west side by 20to 30-ft (6- to 9-m) high berms of the excavated material from the pond site (see Figure 2-3). This excavated material consists mainly of soil and coal ash. There is up to $60 \mathrm{ft}(18 \mathrm{~m})$ of coal ash in the soil column at this location, because of its past use as the ash disposal basin for the 100-D Area. A large amount of coal ash is visible in the strata exposed on the sides of both ponds (DOE-RL 1993a).

\subsubsection{8-D (Coal) Ash Disposal Basin}

The 100-D Ponds are constructed within the boundaries of the old 188-D (Coal) Ash Disposal Basin (see Figure 2-2). From 1944 to 1968 (when the 184-D Powerhouse was decommissioned) coal ash was discharged to the disposal basin in a slurry made up of coal ash and raw Columbia River water. During ash disposal sluicing activities, process sewer effluent was temporarily diverted from its normal path to the 1904-D (Columbia River) Outfall and was routed to the 188-D Ash Disposal Basin. There were no reported process sewer diversions between 1968 and 1977. After the ponds were constructed in the former ash disposal basin, all process sewer liquid effluents were diverted to the 100-D Ponds instead of the Columbia River (DOE-RL 1993a). 
WHC-EP-0666

\subsubsection{3-D Water Treatment Facility}

The 100-D Ponds currently receive effluent discharge from four intermittent nonradioactive, nondangerous waste streams from the 183-D WTF (see Figure 2-2). This facility provides fire protection water and potable water for the 100-D, 100-F, and 100-H Areas. The current average daily discharge rate is $5 \mathrm{gal} / \mathrm{min}(18.9 \mathrm{~L} / \mathrm{min})$. During filter backwash activities, the rate increases to $70 \mathrm{gal} / \mathrm{min}(265 \mathrm{~L} / \mathrm{min})$. The facilities that contribute to these four streams are the 183-D WTF sand filters, clearwells, settling basins, and building floor and trench drains (DOE-RL 1993a). The 183-D WTF has discharged to the ponds from 1977 to the present.

\subsubsection{2-D Reservoir}

The 182-D haservoir stores raw Columbia River water. If the reservoir were to overflow, the 100-D Ponds would receive the excess raw river water (see Figure 2-2). The overflow would contain no sludge or significant sediment concentrations and is therefore considered nonregulated

(DOE-RL 1993a). This facility has had the potential to discharge to the ponds from 1977 to the present.

\subsubsection{9-D Mechanical Development Laboratory}

The 189-D Mechanical Development Laboratory (MDL) operated from 1944 to 1988. Its operations consisted of the collective activities that occurred in the combined 185-D/189-D Building and the attached 190-D, 190-DA, and 1724-DA Buildings (see Figure 2-2). The facilities within these buildings that contributed to the effluent discharge were a mechanical development laboratory; the Thermal Hydraulics Test Facility, which had two hightemperature/high-pressure test loops; a craft shop and storage area; and the Fuel Discharge Trampoline Test Facility. Floor and sink drains within this building complex drain to the process sewer system and therefore the 100-D Ponds (DOE-RL 1992b 1993a).

2.3.5.1 185-D/189-D Building. The 185-L Thermal Hydraulics Test Facility and 189-D MDL occupy the same building and were used for fuel element testing and as thermal hydraulics and mechanical development laboratories (see Figure 2-2). A storage yard (189-D) was located just west of the main building. The Thermal Hydraulics Test Facility used two demineralizers to treat water for the 189-D MDL high-temperature/high-pressure test loops (DOE-RL. 1992b, 1993a). Wastewater from the demineralizers could have been discharged to the process sewer system and the 100-D Ponds from 1977 to 1988.

2.3.5.2 190-D/190-DA/1724-DA Buildings. The 190-D, 190-DA, and 1724-D facilities are part of the same building as 185-D/189-D (see Figure 2-2). The 190-D Building housed the pumphouse operations, the 190-DA Building housed the pumphouse annex operations, and the 1724-DA Building housed the Underwater Test Facility/Fuel Discharge Trampoline Test Facility. The pumphouse and pumphouse annex dealt primarily with filtered and/or chlorinated water. The Underwater Test Facility/Fuel Discharge Trampcline Test Facility contained a mockup of the 100-N Reactor face with a small concrete-lined basin at the base. This setup was used to test 100-N Reactor fuel discharge trampoline components. Unirradiated (green) fuel elements were used in this testing 
(DOE-RL 1992b, 1993a). Water from the unirradiated fuel storage basin and wastewater from the floor and sink drains in the complex could have been

fischarged to the process sewer system and the 100-D Ponds from 1977 to 1988. 
Figure 2-1. Location of the 100-D Area on the Hanford Site.

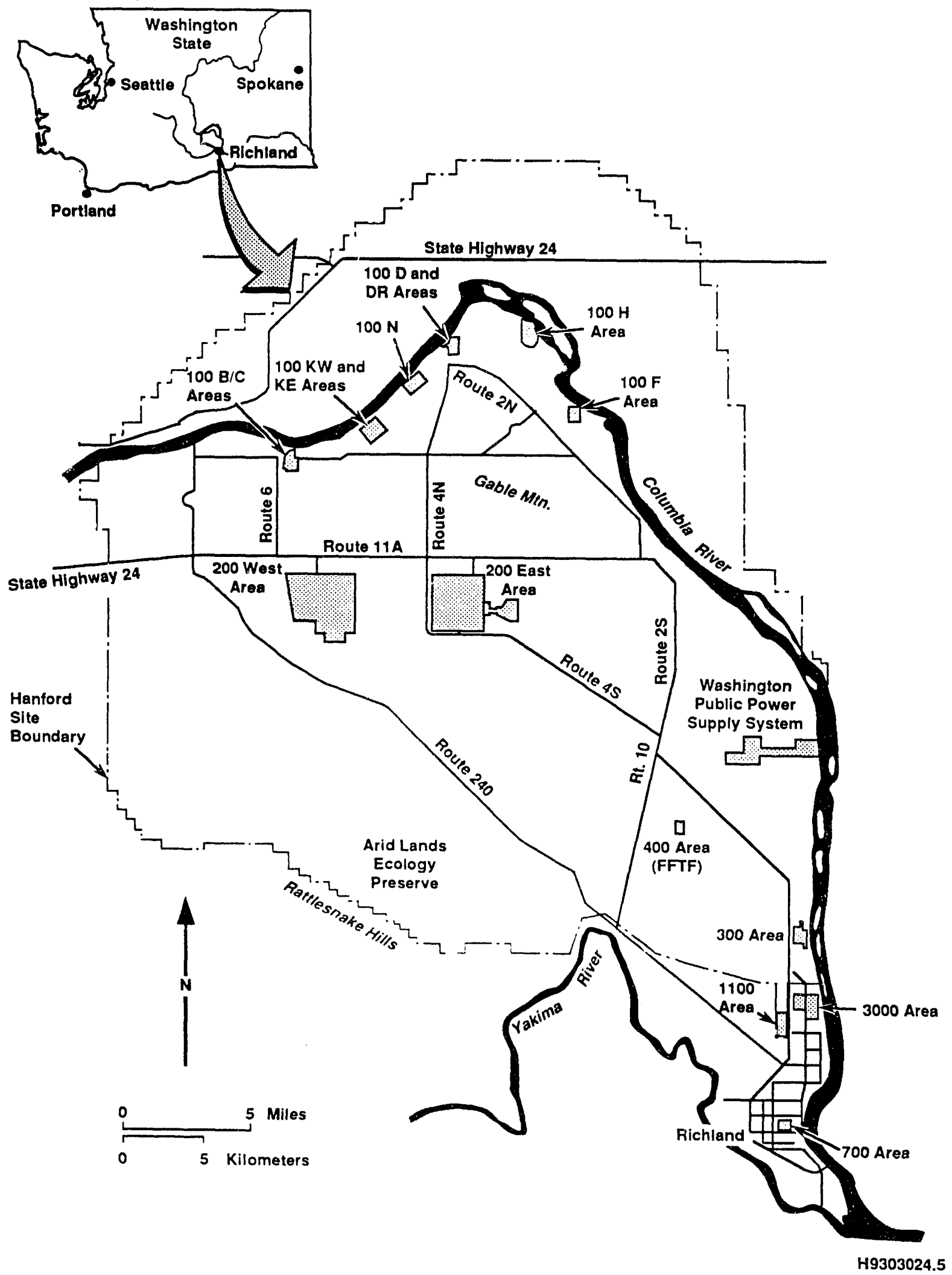


Figure 2-2. Location of the 100-D Ponds in 100-D Area.

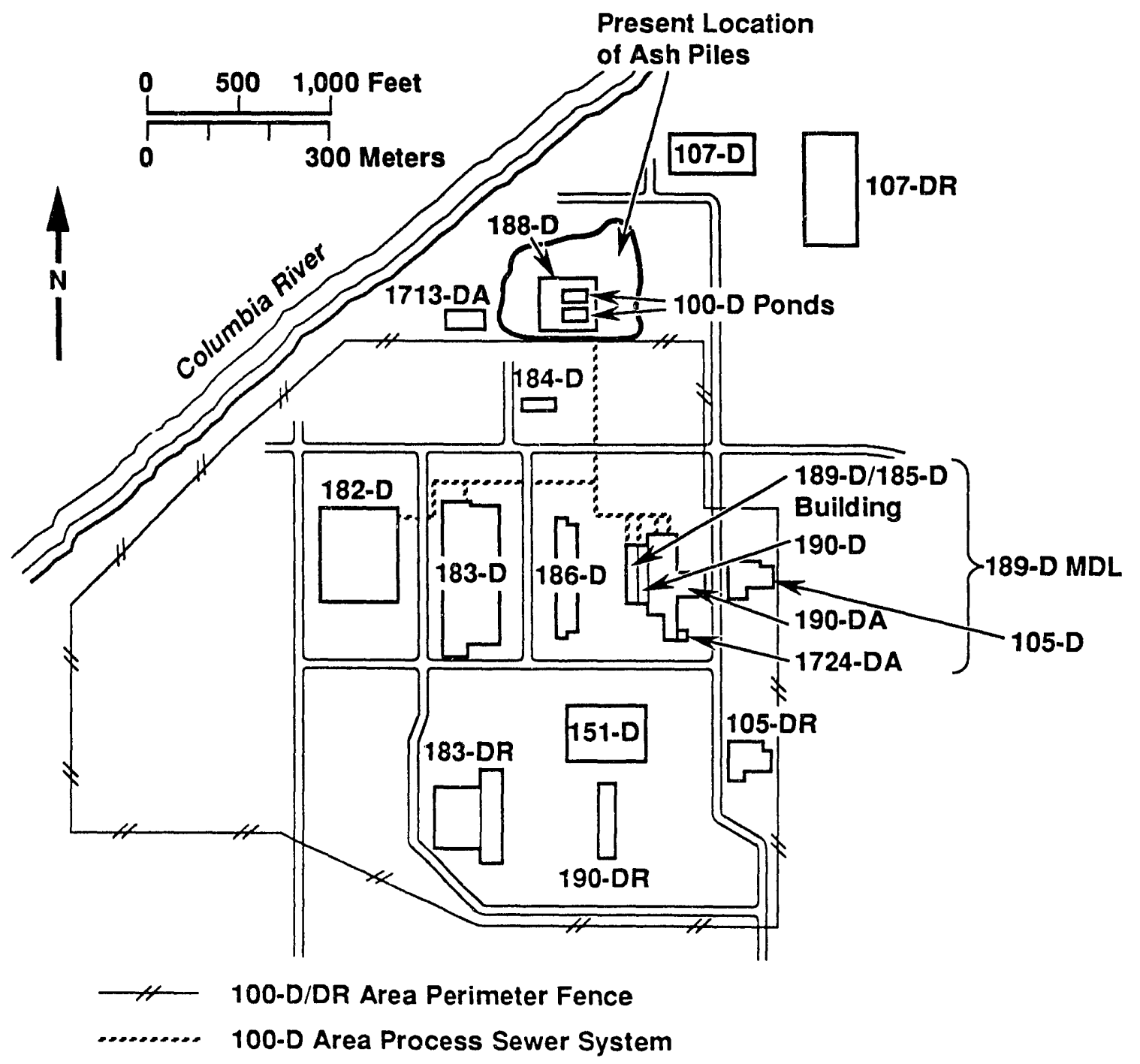

184-D Powerhouse

188-D Ash Disposal Basin (ADB)

100-D Ponds RCRA TSD Unit

183-D Water Treatment Facility (WTF)

182-D Reservoir

189D MDL. Mechanical Development Laboratory

(includes 185-D, 189-D, 190-D, 190-DA, 1724-DA) 
WHC-EP-0666

Figure 2-3. Plan View of the 100-D Ponds.

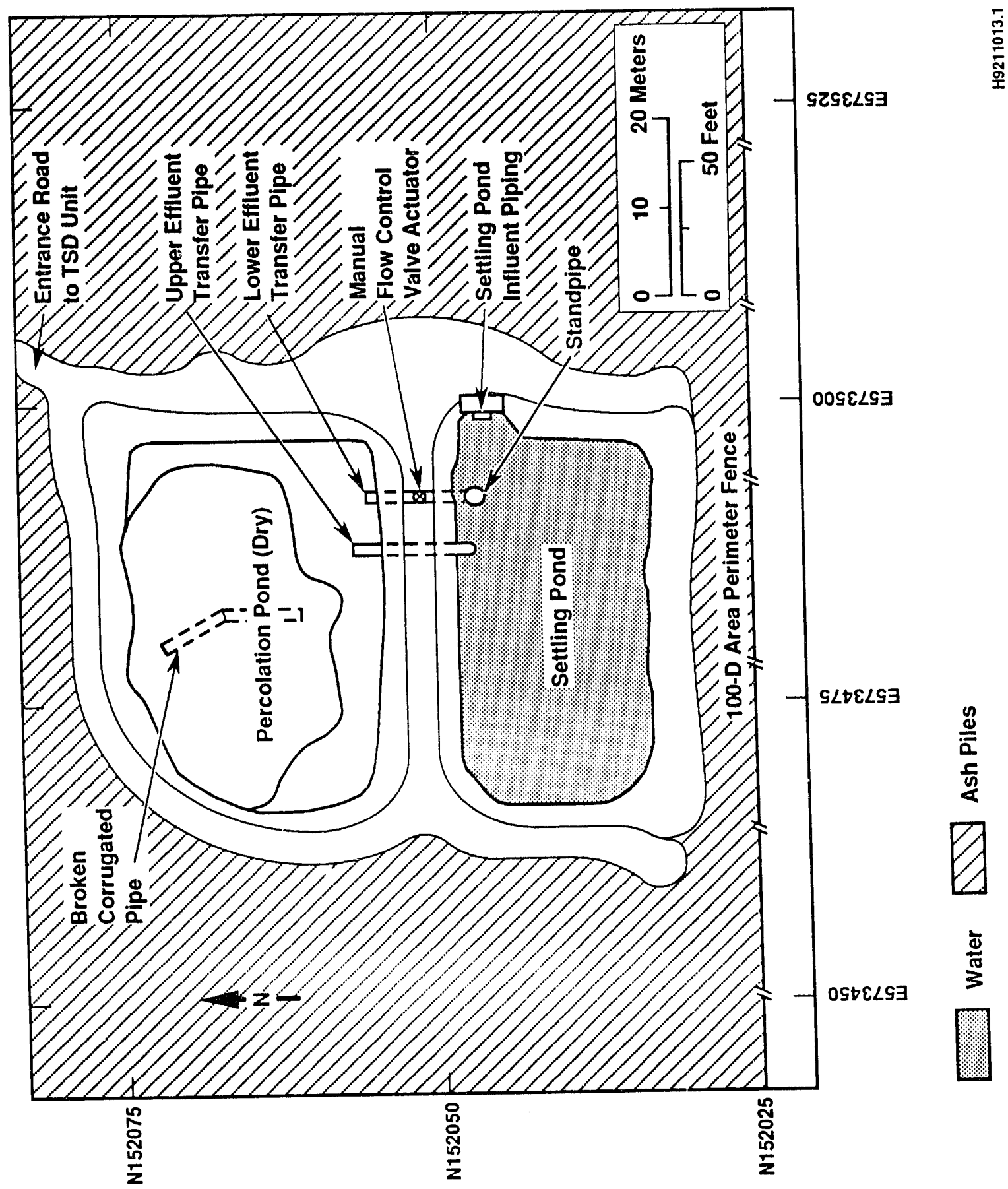


WHC-EP-0666

$2-8$ 
WHC-EP-0666

\subsection{0-D PONDS EFFLUENT CHARACTERISTICS}

\subsection{SOURCES}

\subsubsection{Past-Practice Sources}

The major source of effluent to the 100-D Ponds has always been the 183-D WTF and related facilities. However, other facilities contributed to the effluent stream from 1977 to 1988. These facilities included the 189-D MDL and related facilities. Table 3-1 is a listing of the various effluent stream sources for the 100-D Ponds.

In addition to the types of effluent listed in Table 3-1, there were other potential sources of effluent to the ponds. Until 1988, the ponds may have received effluent discharges from the regeneration of the demineralizers in the 189-D MDL complex. The chemicals involved in this process are hydrochloric and/or sulfuric acid and sodium hydroxide. It is unlikely that any effect from this process will be detected at this time. By their very nature, these substances would neutralize each other and dilute within the large volumes of effluent discharge water from the 183-D WTF.

Prior to 1968, it was common practice to sweep mercury spills (from manometers and switches) into floor and sink drains. At that time, the site was used as the 188-D Ash Disposal Basin, and any mercury disposed in this manner could have entered the drains in the 189-D MDL complex and flowed into the process sewer lines. Mercury in the process sewer lines might have then been sluiced out to the ash disposal basin with the coal ash slurry. Mercury has been visually confirmed in one of the drains in the 189-D MDL building, and therefore is being addressed as a potential contaminant under the RCRA Closure Plan for this site (DOE-RL 1993a).

Other chemicals also used in the shops of the 189-D MDL, such as thinners and solvents, could have entered the pond site via the same route as mercury. These types of chemicals were never procedurally discharged to the process sewer system, but the possibility of spills exists. The large volumes of effluent from the 183-D WTF would have greatly diluted any quantities of spilled chemicals, and therefore it is highly unlikely that any traces of organics will be found. However, sampling for these substances is being addressed as part of the RCRA Closure Plan (DOE-RL 1993a).

The site of the 100-D Ponds is located in the 188-D (Coal) Ash Disposal Basin. Coal ash can be enriched in trace elements, particularly heavy metals, and therefore could affect the chemistry of the pond and groundwater.

\subsubsection{Present Sources}

The 183-D WTF treats raw Columbia River water for fire protection system and potable water for the 100-D, 100-F, and 100-H Areas use (Figure 3-1). The treatment facility consists of the 183-D Settling Basins, the 183-D Facility Multimedia Filter Basins, and the 182-D Reservoir. Wastewater from the filter backwashing and settling basin washdown operations are the processes that 
comprise the majority of the effluent now discharged to the 100-D Ponds (Herman 1992, WHC 1993).

\subsection{SYSTEM CONFIGURATION AND OPERATION}

\subsubsection{Past-Practice Sources}

The following is a description of past-practice effluent sources to the 100-D Ponds, which discharged to the site after the ponds were built in 1977. The 189-D MDL and associated facilities are the primary other sources of effluent discharged to the ponds. The facilities were in operation from 1944 to 1988. A more detailed description of these facilities is found in Section 2.3.5. Post-1977 activities responsible for the discharge of several intermittent streams of liquid effluent were (1) demineralizer recharge effluent drainage, (2) high-temperature and -pressure test loop drainage, (3) Fuel-Discharge Trampoline Test Facility basin drainage, and (4) shop floor and sink drain drainage. Some of these effluent streams may have contained corrosive chemicals and/or radiological contamination. The only pre-1977 effluent from the 189-D MDL discussed here is shop floor and sink drain discharge to the process sewer system before 1974, which presents an historical potential to have deposited elemental mercury in process sewer piping that was later used to send effluent to the 100-D Ponds. The only data that exist for estimating the amount of effluent that was discharged to the ponds is for the 189-D High-Temperature/High-Pressure Loop drainage system. It discharged 200 to 300 jal $(757$ to 1136 L) at an unknown frequency to the 100-D Ponds. There is no data for discharge amounts or frequency from the Fuel Discharge Trampoline Test Facility (DOE-RL 1993a).

\subsubsection{Present Sources}

The 181-D Pumping Station pumps water from the Columbia River into the 182-D Reservoir. Water from the reservoir (approximately 100,000 gal/day $[378,540$ L/day]) is then pumped into the 183-D Settling Basins (Figure 3-2). At this time chlorine gas to control microbial growth and alum to flocculate suspended sediments are added to treat the water. Separan (a trademark of Dow Chemical) was added at the filter plant as an additional flocculent to aid in the filtering process. Separan, which contains sodium carbonate, polyacrylamide, sodium sulfite, and sodium sulfate, was first tested onsite in the mid-1950's as a replacement for activated silica in water treatment processes (Richman 1956), and is no longer in use at 100-D. The treated water is then passed through the 183-D multi-media filters and into the 183-D Clearwells (Herman 1992, WHC 1990C).

The two multimedia filters are backwashed once a month with water from the clearwells to remove trapped sediments. The filters are backwashed by pumping water in the reverse direction through the fi]ters. The pumps (which are rated at $11,000 \mathrm{gal} / \mathrm{min}[41,639 \mathrm{~L} / \mathrm{min}])$ operate for 15 to $20 \mathrm{~min}$ at 1 ess than capacity. This process generates approximately $70,000 \mathrm{gal} / \mathrm{filter}$ $(264,978 \mathrm{~L} / \mathrm{fi}$ ter) for a total $140,000 \mathrm{gal}(529,956 \mathrm{~L})$ of effluent that is discharged via the process sewer system (concrete piping and trenches) to the 100-D Ponds. Floor and trench drains within the 183-D WTF contribute approximately $20 \mathrm{gal}(76 \mathrm{~L}$ ) of effluent to the ponds on a weekly basis. The 
overflow from the clearwells also discharges to the ponds on a contingency basis (Herman 1992, WHC 1990c).

\subsection{DISCHARGE VOLUME AND FLOW REGIME}

\subsubsection{Past-Practice Sources}

Past discharges to the 100-D Ponds are summarized in Table 3-1. The only data for past-practice discharges are 200 to $300 \mathrm{gal}$ (757 to $1136 \mathrm{~L}$ ) of effluent from the 189-D MDL facilities. An annual total is unavajlable. For the purposes of this investigation, the above amount was assumed to be the annual total. The 189-D MDL discharged to the ponds from 1977 to 1988 , giving a total of 2,200 to $3,630 \mathrm{gal}(8,328$ to $12,719 \mathrm{~L})$ discharged to the 100-D Ponds from the 189-D MDL complex. Compared to the present sources of effluent to the ponds, this is a relatively small amount of effluent and would have had a negligible effect on the system as a whole.

\subsubsection{Present Sources}

The current average discharges to the 100-D Ponds consist of $140,000 \mathrm{gal} / \mathrm{mo}(529,958 \mathrm{~L} / \mathrm{mo})$ from filter backwash operations, and 1,440,000 gal/yr $(5,450,993 \mathrm{~L} / \mathrm{yr})$ from settling basin washdown operations. Floor and trench drains in the 183-D WTF contribute 20 gal $(76 \mathrm{~L}$ ) per week of effluent to the ponds. In January 1993 an additional 300,000 gal $(1,135,624 \mathrm{~L})$ of effluent was discharged to the ponds when the settling basins inadvertently emptied. Based on these flow rates and discharges, the total estimated volume of effluent discharged to the ponds for the period January 1977 to May 1993 from these sources is as follows (DOE-RL 1993a):

Filter backwash -

Settling basin washdown -

Floor and trench drains -

January 1993 discharge -

$$
\begin{array}{r}
27,580,000 \text { gal } \\
23,640,000 \text { gal } \\
17,073 \text { gal } \\
+\quad 300,000 \text { gal } \\
\hline 51,537,073 \text { gal }(195,067,821 \mathrm{~L})
\end{array}
$$

\subsection{EFFLUENT CONSTITUENTS}

\subsubsection{Quantities}

The estimated total for past and present effluent sources for the 100-D Ponds from January 1977 through May 1993 is as follows:

Past Sources Present Sources Total All Sources

$$
\begin{aligned}
3,360 \mathrm{gal} & +51,537,073 \mathrm{gal} \\
(12,719 \mathrm{~L}+195,089,043 \mathrm{~L} & =195,101,762 \mathrm{Lal}
\end{aligned}
$$

Table 3-1 and Sections 3.3.1 and 3.3.2 explain these numbers in more detail. 


\subsubsection{Loading Rates}

The information in this section was adapted from the RCRA Closure PIan for the 100-D Ponds (DOE-RL 1993a) and the Liquid Effluent Study Project Final Report (WHC 1990a). It contains actual and potential waste sources for the 100-D Ponds TSD unit as well as radiological and chemical loading estimates (Table 3-2).

3.4.2.1 Estimate of Nondangerous Waste. The major portion of the effluent discharged to the 100-D Ponds (from 1977 to the present) has always come from the 183-D WTF. The four identified waste streams that initiate from this facility were designated as nondangerous based on the following criteria:

- Dangerous Waste Lists (WAC 173-303-080)

- Dangerous Waste Lists (WAC 173-303-100)

- Dangerous Waste Lists (WAC 173-303-090).

The four waste streams were evaluated against the criteria in each of the above sections and did not meet any of the dangerous waste characteristics listed therein (WHC 1990C). The documented discharges from the 189-D MDL complex to the 100-D Ponds were clean streams (see Table 3-1).

3.4.2.2 Estimate of Dangerous Waste. This section addresses the potential for dangerous wastes to have been discharged to the 100-D Ponds. The following dangerous waste constituents were identified using process knowledge and historical information: (1) corrosive chemicals, (2) elemental mercury, (3) dangerous shop chemicals, (4) radiological constituents (addressed merely for information), and (5) coal ash contaminants (i.e., trace inetals). The estimated maximum potential volume of dangerous wastes received by the 100-D Ponds is given in Table 3-3.

3.4.2.2.1 Corrosive Chemicals. From 1977 to 1986, the 189-D MDL occasionally discharged potentially corrosive efflueris to the process sewer system and ultimately to the 100-D Ponds. This effluent consisted of potentially corrosive liquids from the regeneration of three demineralizers. These effluents may have had $\mathrm{pH}$ values of as $10 \mathrm{w}$ as 2.0 or as high as 12.5 when they arrived at the ponds, but there are no records to verify this possibility. This potential for having received corrosive effluent is what caused the ponds to become a RCRA TSD unit (DOE-RL 1993a)

It is estimated that no more than eight regeneration events took place during the operation of the demineralizers. The amounts of chemicals used during regeneration are reported as $951 \mathrm{~b}(43 \mathrm{~kg})$ sodium hydroxide and $70 \mathrm{lb}$ $(32 \mathrm{~kg})$ hydrochloric or sulfuric acid. The maximum potential inventory is estimated at $760 \mathrm{lb}(344 \mathrm{~kg})$ sodium hydroxide and $5601 \mathrm{~b}(253 \mathrm{~kg})$ acid.

It is highly unlikely that any chemicals persist at the ponds in a corrosive state at present. Even if corrosive chemicals had been discharged to the ponds, the naturally occurring slightly alkaline sediments/coal ash in the unlined pond would have eventually neutralized the effluent. The process of regeneration is performed by injecting acid and base in sequence or cogenerating them (required by procedures after 1986) into the system. The effluent was diluted twice with water during the process and checked with litmus paper before disposal. This neutral (nondangerous) effluent was then disposed of to the ponds. RCRA effluent sampling performed in the 
100-HR-3 Operable Unit for the closure plan indicated pH values in the 6 to 7 range (neutral), wirich is considered normal for this effluent (DOE-RL 1993a).

3.4.2.2.2 Elemental Mercury. The presence of elemental mercury was confirmed in the floor drain of the 189-D MDL in 1989 (Prire 1989). This drain branches off the main process sewer system that drains to the 100-D Ponds. This discovery indicates the potential for mercury spilled from manometers and switches to have entered the drain and therefore the ponds. There are no records to check for this possibility, so investigation personnel determined a worst-case estimate. The estimate used was $51 \mathrm{~b}(2.6 \mathrm{~kg})$ as the total amount spilled from equipment (Price 1989).

It is assumed that only a small amount of this estimated quantity could have actualiy reached the pond system. Between 1950 and 1968, the operational period of the 188-D Ash Disposal Basin, coal ash slurries could have carried small amounts of elemental mercury to the ponds from the powerhouse ash sluicing operations. From 1968 until 1977 (when the nonds were built), there were no discharges to this site. In 1974, mercury traps were placed on 189-D MDL instruments, which effectively stopped any mercury from entering the piping system after that time. Therefore, the maximum amount of mercury that could have entered the system is much less than the $5-1 \mathrm{~b}(2.6-\mathrm{kg})$ estimate, and this residual mercury would remain in the proce;s sewer piping. After 1977 , the process sewer system discharged at a reduced rate (as compared to pre-1966 flow rates to the Columbia River). Any elemental mercury remaining in the process sewer would most likel.: still be in the system piping or be very close to the influent line in the settling pond. Mercury found elsewhere in the ponds is assumed to be attributed to the coal ash that was deposited at this site (DOE-RL 1993a).

3.4.2.2.3 Dangerous Shop Chemicais. Commonly used volatile shop chemicals such as thinners or solvents could have been released to the 100-D Ponds through open floor and sink drains within the 189-D MDL complex. However, this facility did not normally store any of these chemicals in bulk quantities. In addition, the facility proced'sres did not discharge these types of chemicals into the process sewer system. It is reasonable to assume that any spills would have been of small quantities and that the larger volume of effluent in the system would dilute them. Chemical persistence and detectability would decrease with time due to volatilization and degradation. Volatile organics are included in the analyte list for samples collected for operable unit characterization studies (DOE-RL 1993a).

3.4.2.2.4 Radioactive Constituents. The potential for radiologica? contamination in the 100-D Ponds is minimal, based on process knowledge. Unirradiated uranium fuel elements were used at the 189-D iMDL Fuel Discharge Trampoline Test Facility for fuel discharge trampoline testing and occasionally were reported to have been purposely ruptured. However unlikely, the rupture of fuel elements could have resulted in radiological contamination of the test basin and subsequently the ponds. This possibility is being investigated through sampling of the 100-DR-l Operable Unit (DOE-RL 1993a).

3.4.2.2.5 Coal Ash Contaminants. The 100-D Ponds are built within the oid 188-D (Coal) Ash Disposal Basin. The coal ash was excavated to create the punds diru therefore is found on the sides and bottom of the pond, making up the bulk of the surrounding sediment (DOE-RL 1993a). 
Studies of the coal and coal ash at Hanford show that the coal is relatively "clean" (low concentrations of metals, sulfur, etc.) and that the ash is nonradioactive and nondangerous per WAC 173-303 (DOE-RL 1992c, Wilson 1990, Rasmussen and Carlson 1987, Dorian and Richards 1978). Table 3-4 is a comparison of data from a recent analysis of Hanford coal ash slurry leachate with the Washington State dangerous waste (DW) regulations (WAC 173-303) and the Washington State water quality standards (WWQS) (WAC 173-200). Table 3-5 shows results for three leachate samples (coal, bottom ash, and fly ash) from the 200-E Powerhouse. Table 3-6 displays results from 12 samples of mixed fly and bottom ash leachate from both 200-E and 200-W Powerhouses. It is believed that coal in use at Hanford has historically come from the same places from which the site is receiving coal today. Also, the past methods used to process and burn coal are similar to present practices. Therefore, these results should be analogous to the coal ash at 100-D Area. The coal ash in the 100-D Area is also being sampled as part of the 100-DR-1 Operable Unit sampling activities (DOE-RL 1993a, 1992b).

The results given in Table 3-4 show that the coal ash slurry leachate does not exceed any of the DW criteria (WAC 173-303) and is therefore designated nondangerous. However, it does exceed or could potentially exceed several WWQS criteria (WAC 173-200). The pH of the slurry is alkaline and almost a full $\mathrm{pH}$ unit above the maximum allowed by state regulations $(29.5)$. In addition, it exceeds the fluoride and sulfate regulatory standards. The EP toxicity tests for arsenic, cadmium, chromium, lead, selenium, and silver were performed with too high a detection limit for comparison with WWQS criteria.

Table 3-5 shows that there are concentration differences in the leachate based on the initial form of the coal, i.e., coal vs. coal ash. The coal leachate tends to be an order of magnitude less in concentration than the coal ash leachate for most parameters of interest. The bottom ash and fly ash leachate appear to have comparable concentrations for most parameters. Arsenic, barium, chromium, copper, fluorine, lead, mercury, and selenium values exceed the WWQS by at least two orders of magnitude. Cadmium and silver values have too high a detection limit to be of any use for comparison to the standard. While leachate data are useful, actual groundwater samples are a better indicator of contamination or exceedance of the standards. The leachate would be diluted by intermixing with pond effluents and groundwater.

In Table 3-6, the detection limits make most of these data unusable for comparison to the groundwater standards. The barium data just barely exceed the WWQS. Mercury values are at the WWQS but do not exceed it. The pH of all but four of the samples falls outside the WWQS PH range on the alkaline side. This is to be expected for coal ash leachate samples, and it would be reduced when mixed with raw water for sluicing purposes. The data given do show that the coal ash does not exceed state DW criteria and is therefore designated as nondangerous.

\subsubsection{Operational Factors}

Effluent discharged to the 100-D Ponds currently consists of Columbia River water that has been filtered to remove suspended solids, treated with alum to flocculate out additional suspended solids, and then treated with chlorine gas as a disinfectant. These processes could cause elevated (above 
normal river water) concentrations of aluminum and chlorine in the resultant effluent stream.

\subsection{CONSTITUENTS OF INTEREST AND KEY PARAMETERS}

The key constituents of interest identified in the Liquid Effluent Study (WHr. 1990a) are chromium, iron, lead, manganese, mercury, sulfate, and alumii:Im. All of these parameters have exceeded the WWQS in effluent samples. In addition to these parameters, trichloromethane (chloroform) and arsenic have also exceeded the WWQS. Table 3-7 shows the averaged sample results for the years 1987 to 1990 , compared with the WWQS.

Iron, manganese, and trichloromethane exceeded the standards for all four years. Chromium, lead, mercury, and sulfate exceeded the standards only in 1987. The pH values for 1987 and 1989 were below the lower end of the regulatory standard range for $\mathrm{pH}$, with slightly acidic values. Arsenic exceeded the standard in 1989 and 1990, but it should be noted that the values for arsenic are within the normal background range for the Hanford Site (DOE-RL 1992d, Johnson 1993). With a few exceptions, almost all of the parameters showed their highest values in the 1987 sample set, with markedly lower values in subsequent years. This is not unexpected as all other facilities that contributed to the effluent stream shut down in-1988, leaving the 183-D WTF as the only regular contributor to the effluent stream. 
WHC-EP-0666

$3-8$ 
Figure 3-1. The 183-D Water Treatment Facility (WTF) (Herman 1992).
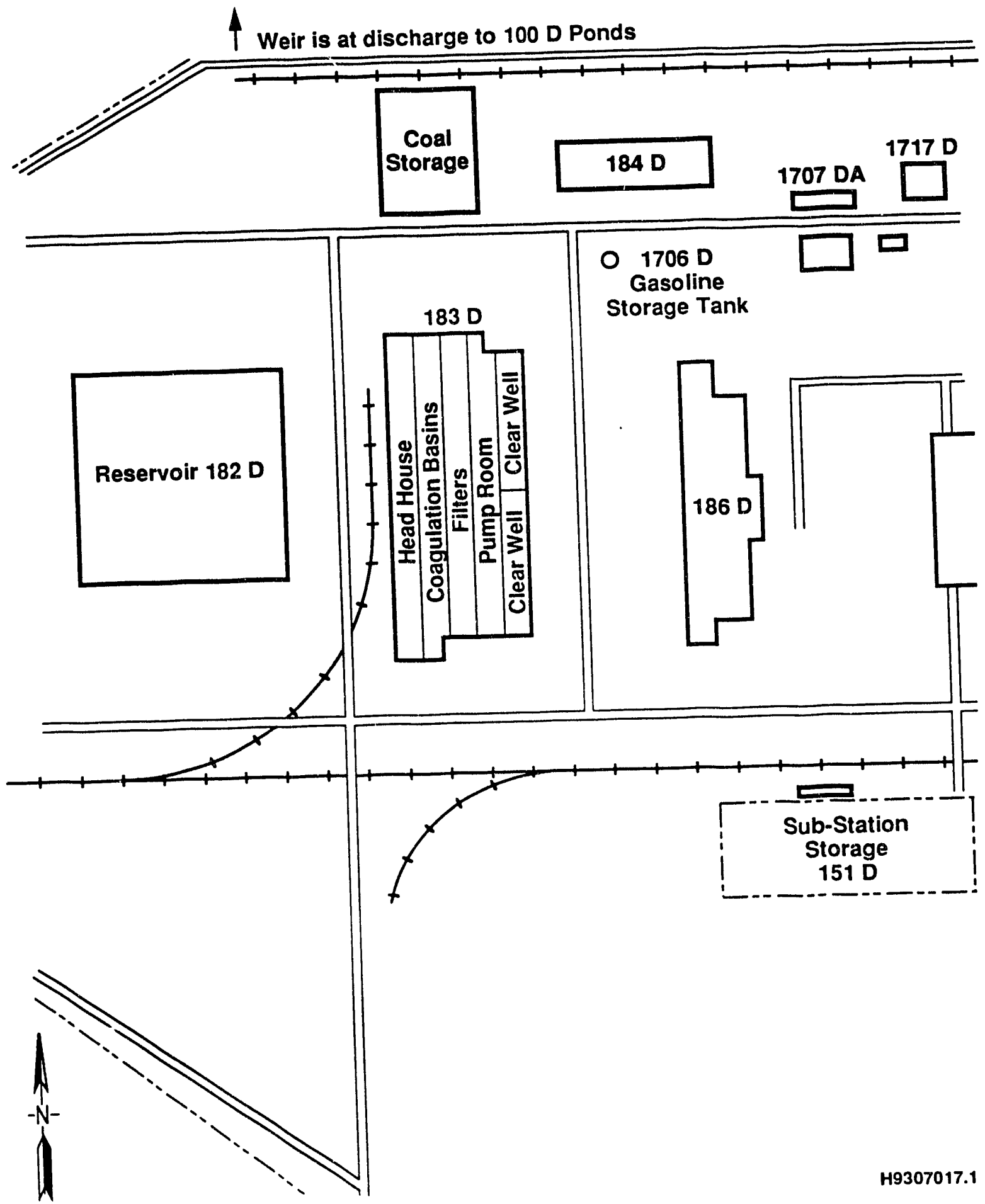
Figure 3-2. Flow Schematic of the 100-D Water Treatment Facilities.
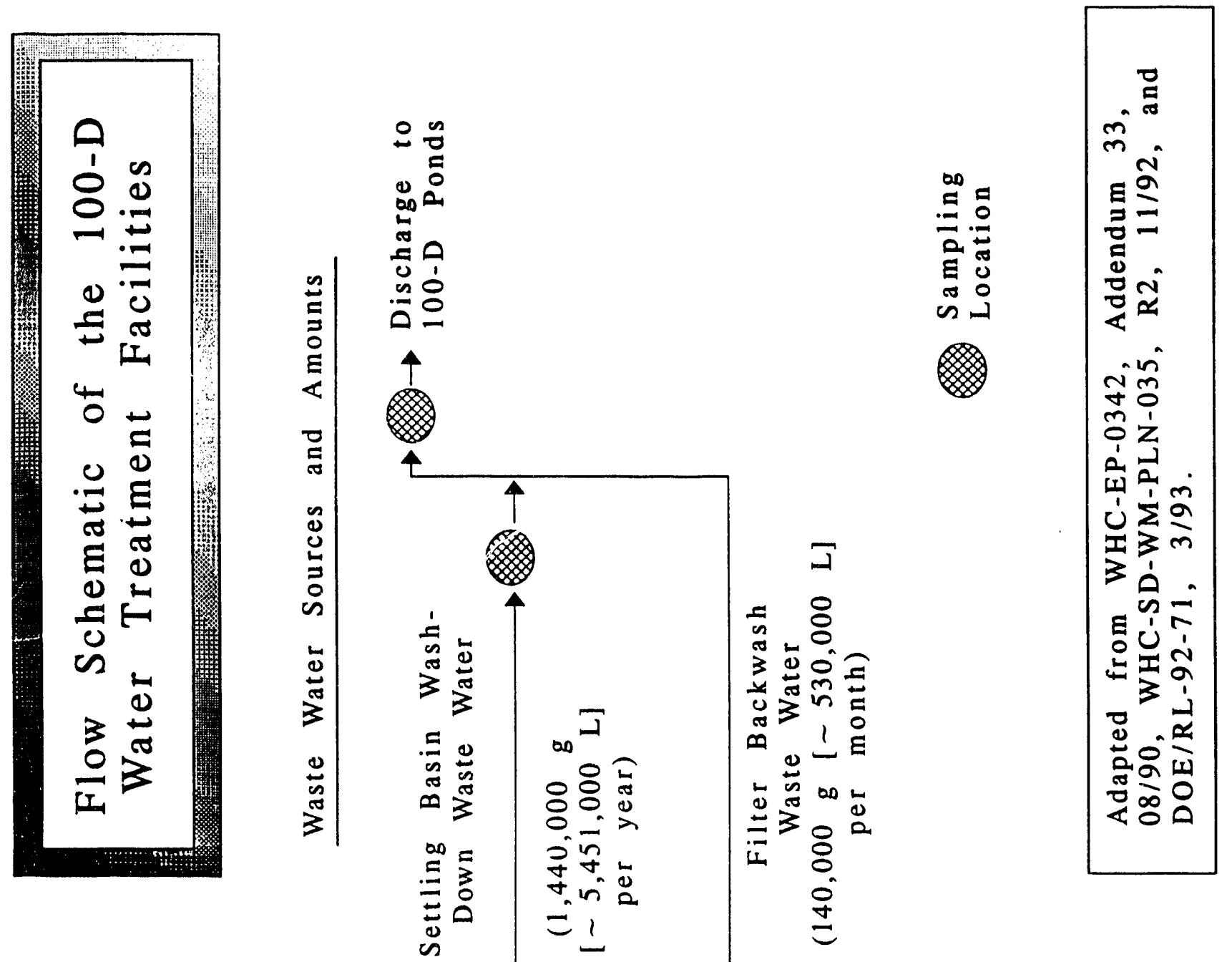

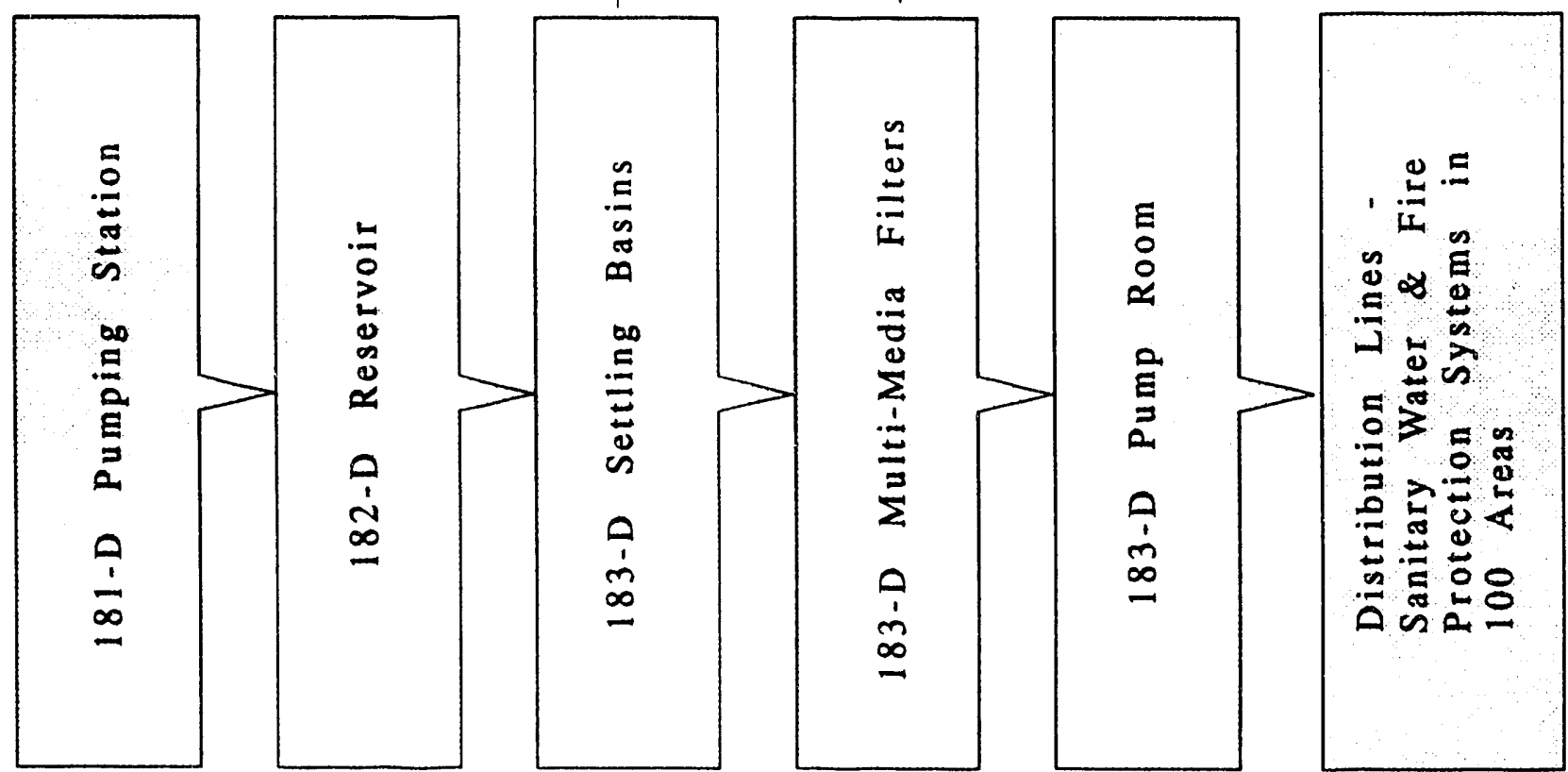


Table 3-1. Past and Present Effluent Stream Sources and Amounts Discharged to the 100-D Ponds (adapted and modified from DOE-RL 1993a).

\begin{tabular}{|c|c|c|c|c|c|}
\hline \multirow[t]{2}{*}{ Stream origin } & \multirow{2}{*}{$\begin{array}{l}\text { Release } \\
\text { Period }\end{array}$} & \multirow[t]{2}{*}{ Effluent } & \multirow[t]{2}{*}{ Frequency } & \multicolumn{2}{|c|}{ Quantity - gal (L) } \\
\hline & & & & Per event & Annual \\
\hline \multicolumn{6}{|l|}{ 183-D WTF: } \\
\hline $\begin{array}{l}\text { - Sand-filter backwash } \\
\text { (totals for both filters) }\end{array}$ & $\begin{array}{l}1977 \text { to } \\
\text { present }\end{array}$ & $\begin{array}{l}\text { Sanitary water, } \\
\text { alum, and raw } \\
\text { river watel }\end{array}$ & Monthly & $\begin{array}{l}140,000 \\
(-530,000)\end{array}$ & $\begin{array}{l}1,680,000 \\
(\sim 6,360,000)\end{array}$ \\
\hline $\begin{array}{l}\text { - } 183-D \text { Settling basin } \\
\text { washdown (totals for both } \\
\text { basins) }\end{array}$ & Same & Same & Bi-Annually & $\begin{array}{l}720,000 \\
(\sim 2,725,200)\end{array}$ & $\begin{array}{l}1,440,000 \\
(-5,451,000)\end{array}$ \\
\hline \multirow[t]{2}{*}{ - Floor and trench drains } & \multirow[t]{2}{*}{ Same } & \multirow[t]{2}{*}{ Sanitary water } & Weekly & $\begin{array}{l}20 \\
(\sim 76)\end{array}$ & $\begin{array}{l}1040 \\
(-3937) \\
\end{array}$ \\
\hline & & & \multicolumn{3}{|c|}{ Cont ingency } \\
\hline 182-D Reservoir overflow & Same & Raw river water & \multicolumn{3}{|c|}{ Cont ingency } \\
\hline \multirow{2}{*}{$\begin{array}{l}\text { 189-D MDL: } \\
\text { - High-temperature/high- } \\
\text { pressure loop drainage }\end{array}$} & & & & & \\
\hline & $\begin{array}{l}1977 \text { to } \\
1986\end{array}$ & $\begin{array}{l}\text { Demineralized } \\
\text { water }\end{array}$ & Undocumented & $\begin{array}{l}200-300 \\
(\sim 757-1136)\end{array}$ & $\begin{array}{l}\text { Undocu- } \\
\text { mented }\end{array}$ \\
\hline $\begin{array}{l}\text { - Fuel discharge } \\
\text { Trampol ine Test Facility }\end{array}$ & Same & $\begin{array}{l}\text { Filtered/ } \\
\text { chlorinated } \\
\text { water }\end{array}$ & Same & $\begin{array}{l}\text { Indeter- } \\
\text { minate }\end{array}$ & Same \\
\hline
\end{tabular}

WTF: Water Treatment Facility

MOL: Mechanical Development Laboratory 
Table 3-2. Radionuclide and Chemical Loading, 183-D Filter Backflush Wastewater (WHC 1990a).

Flow rate: $1.89 \mathrm{E}+05 \mathrm{~L} / \mathrm{mo}$

\begin{tabular}{|c|c|c|c|c|c|}
\hline Constituent & $\mathrm{kg} / \mathrm{L}^{\mathrm{a}}$ & $\mathrm{kg} / \mathrm{mo}^{\mathrm{a}}$ & Constituent & $\mathrm{kg} / \mathrm{L}^{\mathrm{a}}$ & $\mathrm{kg} / \mathrm{mo}^{\mathrm{a}}$ \\
\hline Aluminum & $2.25 \mathrm{E}-05$ & $4.26 E+00$ & Sulfate & $1.72 \mathrm{E}-05$ & $3.26 E+00$ \\
\hline Arsenic & $8.75 E-09$ & $1.66 \mathrm{E}-03$ & Uranium & $3.53 E-09$ & $6.68 \mathrm{E}-04$ \\
\hline Barium & $4.45 E-08$ & $8.42 E-03$ & Vanadium & $7.25 E-09$ & $1.37 E-03$ \\
\hline Boron & $2.50 \mathrm{E}-08$ & $4.73 E-03$ & Zinc & $6.02 E-08$ & $1.14 E-02$ \\
\hline Calcium & $2.05 E-05$ & $3.88 E+00$ & Ammonia & $6.45 E-08$ & $1.22 E-02$ \\
\hline Chloride & $2.85 E-06$ & $5.39 E-01$ & 2-butanone & $1.07 \mathrm{E}-08$ & $2.02 E-03$ \\
\hline Chromium & $1.37 \mathrm{E}-08$ & $2.59 E-03$ & Trichloromethane & $2.05 E-08$ & $3.88 E-03$ \\
\hline Copper & $4.25 E-08$ & $8.04 E-03$ & $\begin{array}{l}\text { Unknown } \\
\text { al iphatic } \\
\text { hydrocarbon }\end{array}$ & $4.00 \mathrm{E}-07$ & $7.57 \mathrm{E}-02$ \\
\hline Fluoride & $1.59 \mathrm{E}-07$ & $3.01 E-02$ & Unknown compound & $1.60 \mathrm{E}-06$ & $3.03 E-01$ \\
\hline Iron & $2.61 \mathrm{E}-06$ & $4.94 \mathrm{E}-01$ & $\begin{array}{l}\text { Unknown fatty } \\
\text { acid }\end{array}$ & $1.45 E-08$ & $2.74 E-03$ \\
\hline Lead & $1.00 E-08$ & $1.89 E-03$ & Alpha activity ${ }^{a}$ & $3.90 E-12$ & $7.38 \mathrm{E}-07$ \\
\hline Magnesium & $4.57 E-06$ & $8.65 E-01$ & $\begin{array}{l}\text { Beta } \\
\text { activity }\end{array}$ & $3.53 E-12$ & $6.68 E-07$ \\
\hline Manganese & $8.15 E-08$ & $1.54 \mathrm{E}-02$ & $\begin{array}{l}\text { Suspended } \\
\text { solids }\end{array}$ & $0.375-05$ & $1.21 \mathrm{E}+01$ \\
\hline Mercury & $7.37 \mathrm{E}-10$ & $1.39 E-04$ & $\begin{array}{l}\text { Total dissolved } \\
\text { solids }\end{array}$ & $7.65 \mathrm{E}-05$ & $1.45 E+01$ \\
\hline Potassium & $8.63 E-07$ & $1.63 \mathrm{E}-01$ & $\begin{array}{l}\text { Total organic } \\
\text { carbon }\end{array}$ & $7.05 E-06$ & $1.33 E+00$ \\
\hline Silicon & $5.17 E-06$ & $9.78 \mathrm{E}-01$ & Total carbon & $1.49 \mathrm{E}-05$ & $2.82 E+00$ \\
\hline Sodium & $2.34 E-06$ & $4.43 E-01$ & $\begin{array}{l}\text { Total organic } \\
\text { hal ides } \\
\text { as Chloride }\end{array}$ & $2.00 \mathrm{E}-07$ & $3.79 E-02$ \\
\hline Strontium & $1.13 E-07$ & $2.14 \mathrm{E}-02$ & Ruthenium- $66^{a}$ & $1.29 \mathrm{E}-11$ & $2.44 E-06$ \\
\hline
\end{tabular}

NOTES:

1. Data collected from October 1989 through March 1990.

2. Flow rate is average of rates from the Hanford Site StreamSpecific Reports (WHC 1990c, Addendum 33).

3. Constituent concentrations are average values from the statistics in the Hanford Site Stream-Specific Reports

(WHC 1990C, Addendum 33).

${ }^{a}$ Concentration units of these constituents are reported as curies per liter. Loading units of these constituents are reported as curies per month. 
Table 3-3. Maximum Potential Inventory of Dangerous Waste to 100-D Ponds (DOE-RL 1993a).

\begin{tabular}{|c|c|c|}
\hline Stream Origin & Stream Constituents & $\begin{array}{c}\text { Total Quantity } \\
\mathrm{kg}(1 \mathrm{~b})\end{array}$ \\
\hline \multicolumn{3}{|c|}{ 189-D Mechanical Development Laboratory } \\
\hline \multirow[t]{2}{*}{ Demineralizer recharge } & $\begin{array}{l}\text { Hydrochloric and/or } \\
\text { sulfuric acid }\end{array}$ & $245.0(560)$ \\
\hline & Sodium hydroxide & $344.7(760)$ \\
\hline Floor and sink drains & Mercury & $2.3(5)$ \\
\hline
\end{tabular}


Table 3-4. 200 Area Coal Ash Slurry Leachate Analysis Results (Wilson 1990).

\begin{tabular}{|c|c|c|c|c|c|c|c|}
\hline Parameter & $\begin{array}{l}\text { Anal. } \\
\text { Results }\end{array}$ & $\begin{array}{c}\text { WAC } \\
173-200 \\
\text { WWOS Lmts }\end{array}$ & $\begin{array}{c}\text { WAC } \\
173-303 \\
\text { DW Lmts }\end{array}$ & Parameter & $\begin{array}{l}\text { Anal. } \\
\text { Results }\end{array}$ & $\begin{array}{c}\text { WAC } \\
173-200 \\
\text { WWQS Lmts } \\
\end{array}$ & $\begin{array}{c}\text { WAC } \\
173-303 \\
\text { DW Lmts }\end{array}$ \\
\hline $\mathrm{pH}$ & 9.42 & $6.5-8.5$ & $\geq 2 \quad-\leq 12.5$ & Potassium & * $1000 \mathrm{ppb}$ & $\cdots$ & - \\
\hline Nitrate & $7.00 \mathrm{ppm}$ & $10 \mathrm{ppm}$ & $\ldots$ & Iron & * $300 \mathrm{ppb}$ & $300 \mathrm{ppb}$ & $\cdots$ \\
\hline Sulfate & $471 \mathrm{ppm}$ & $250 \mathrm{ppm}$ & $\because$ & Magnesium & $3430 \mathrm{ppb}$ & $\cdots$ & - \\
\hline Fluoride & $12.6 \mathrm{ppm}$ & $4.0 \mathrm{ppm}$ & - & EPT-Arsenic & * $500 \mathrm{ppb}$ & $0.05 \mathrm{ppb}$ & $5000 \mathrm{ppb}$ \\
\hline Chloride & * $2.50 \mathrm{ppm}$ & $250 \mathrm{ppm}$ & $\cdots$ & EPT-Barium & * $1000 \mathrm{ppb}$ & $1000 \mathrm{ppb}$ & $100,000 \mathrm{ppb}$ \\
\hline Phosphate & $\star 5.00 \mathrm{ppm}$ & $\cdots$ & - & EPT-Cadmium & * $100 \mathrm{ppb}$ & $10 \mathrm{ppb}$ & $1000 \mathrm{ppb}$ \\
\hline Bromide & * $5.00 \mathrm{ppm}$ & - & - & $\begin{array}{c}\text { EPT - } \\
\text { Chromium }\end{array}$ & * $500 \mathrm{ppb}$ & $50 \mathrm{ppb}$ & $5000 \mathrm{ppb}$ \\
\hline Nitrite & $\star 5.00 \mathrm{ppm}$ & - & $\ldots$ & EPT-Lead & * $500 \mathrm{ppb}$ & $50 \mathrm{ppb}$ & $5000 \mathrm{ppb}$ \\
\hline Beryllium & $\star 50 \mathrm{ppb}$ & $\cdots$ & -- & $\begin{array}{c}\text { EPT - } \\
\text { Selenium } \\
\end{array}$ & $\star 500 \mathrm{ppb}$ & $10 \mathrm{ppb}$ & $1000 \mathrm{ppb}$ \\
\hline Strontium & $2080 \mathrm{ppb}$ & - & $\ldots$ & EPT-Silver & * $500 \mathrm{ppb}$ & $50 \mathrm{ppb}$ & $5000 \mathrm{ppb}$ \\
\hline Zinc & * $50 \mathrm{ppb}$ & $\cdots$ & 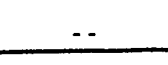 & Boron & $1460 \mathrm{ppb}$ & $\cdots$ & $\cdots$ \\
\hline Calcium & $28,700 \mathrm{ppb}$ & $\ldots$ & $\because$ & Cobalt & * $200 \mathrm{ppb}$ & $\cdots$ & $\ldots$ \\
\hline Sodium & $3640 \mathrm{ppb}$ & $\cdots$ & $\because$ & Lithium & * $100 \mathrm{ppb}$ & - & - \\
\hline Nickel & * 100 ppb & $\ldots$ & $\ldots$ & Molybdenum & $\star 400 \mathrm{ppb}$ & $\cdots$ & $\cdots$ \\
\hline Copper & * $100 \mathrm{ppb}$ & $1000 \mathrm{ppb}$ & $\cdots$ & silicon & $2780 \mathrm{ppb}$ & $\cdots$ & $\cdots$ \\
\hline Vanadium & * $50 \mathrm{ppb}$ & $\ldots$ & $\cdots$ & Tin & * $300 \mathrm{ppb}$ & $\ldots$ & $\cdots$ \\
\hline Antimony & * $1000 \mathrm{ppb}$ & $\cdots$ & $\cdots$ & Titanium & * $600 \mathrm{ppb}$ & - & $\cdots$ \\
\hline Aluminum & * $1500 \mathrm{ppb}$ & $\cdots$ & $\therefore$ & Zirconium & $\star 500 \mathrm{ppb}$ & - & $\cdots$ \\
\hline Manganese & * $50 \mathrm{ppb}$ & $50 \mathrm{ppb}$ & -- & -- & $\cdots$ & -- & $\cdots$ \\
\hline
\end{tabular}

*Denotes a result less than detection limit.

WAC=Washington , Iministrative Code 
Table 3-5. Analytical Results for Coal and Coal Ash Leachate Samples (DOE-RL 1992C).

\begin{tabular}{|l|c|c|c|c|}
\hline \multirow{2}{*}{$\begin{array}{c}\text { Constituent } \\
\text { in leachate } \\
\text { (ppm) }\end{array}$} & \multicolumn{3}{|c|}{ Sample number } & \multirow{2}{*}{$\begin{array}{c}\text { WWQS } \\
\text { (ppm) }\end{array}$} \\
\cline { 2 - 4 } & WHC-S-1 & WHC-BA-2 & WHC-GA-1 & \\
\hline Antimony & $<20$ & $<20$ & $<20$ & -- \\
\hline Arsenic & 165 & 2.0 & 31.3 & 0.00005 \\
\hline Barium & 217 & 1370 & 2230 & 1.0 \\
\hline Beryllium & $<5$ & $<5$ & 6 & -- \\
\hline Boron & 148 & 690 & 1060 & -- \\
\hline Cadmium & $<6$ & $<5$ & $<5$ & 0.01 \\
\hline Chlorine & 100 & $<100$ & 200 & 250 \\
\hline Chromium & 8.6 & 94 & 140 & 0.05 \\
\hline Cobalt & 4.5 & 30 & 28 & -- \\
\hline Copper & 9.0 & 52 & 74 & 1.0 \\
\hline Fluorine & 100 & $<100$ & 300 & 4.0 \\
\hline Germanium & $<10$ & $<10$ & 10 & -- \\
\hline Lead & $<10$ & 48 & 60 & 0.05 \\
\hline Lithium & 6 & 40 & 40 & -- \\
\hline Mercury & $<0.2$ & 0.3 & 0.2 & 0.002 \\
\hline Molybdenum & $<0.3$ & $<3$ & $<3$ & -- \\
\hline Nickel & 3.7 & 34 & 32 & -- \\
\hline Selenium & 0.06 & 0.6 & 2.4 & 0.01 \\
\hline Silver & $<0.5$ & $<5$ & $<5$ & 0.05 \\
\hline Thallium & $<5$ & $<50$ & $<50$ & -- \\
\hline Tungsten & $<3$ & $<30$ & $<30$ & -- \\
\hline Uranium & 0.5 & 6 & 6 & -- \\
\hline Vanadium & $<5$ & $<50$ & $<50$ & -- \\
\hline Zinc & 13 & 76 & 87 & -1 \\
\hline
\end{tabular}

Samples: (1) WHC-S-1: Coal from Surge Bin at Boiler \#3; (2) WHC-BA-2: Bottom ash - Boiler \#3; (3) WHC-GA-1: Fly ash Boiler \#3; all samples from 200-E Powerhouse. WWQS=Washington State water quality standards 
Table 3-6. Summary of TCLP Metals and pH Analytical Results for Fly and Bottom Ash Leachate Mixtures (DOE-RL 1992C). (All samples are mixtures of f7y and bottom ash collected from 200-E or 200-W Powerhouses.)

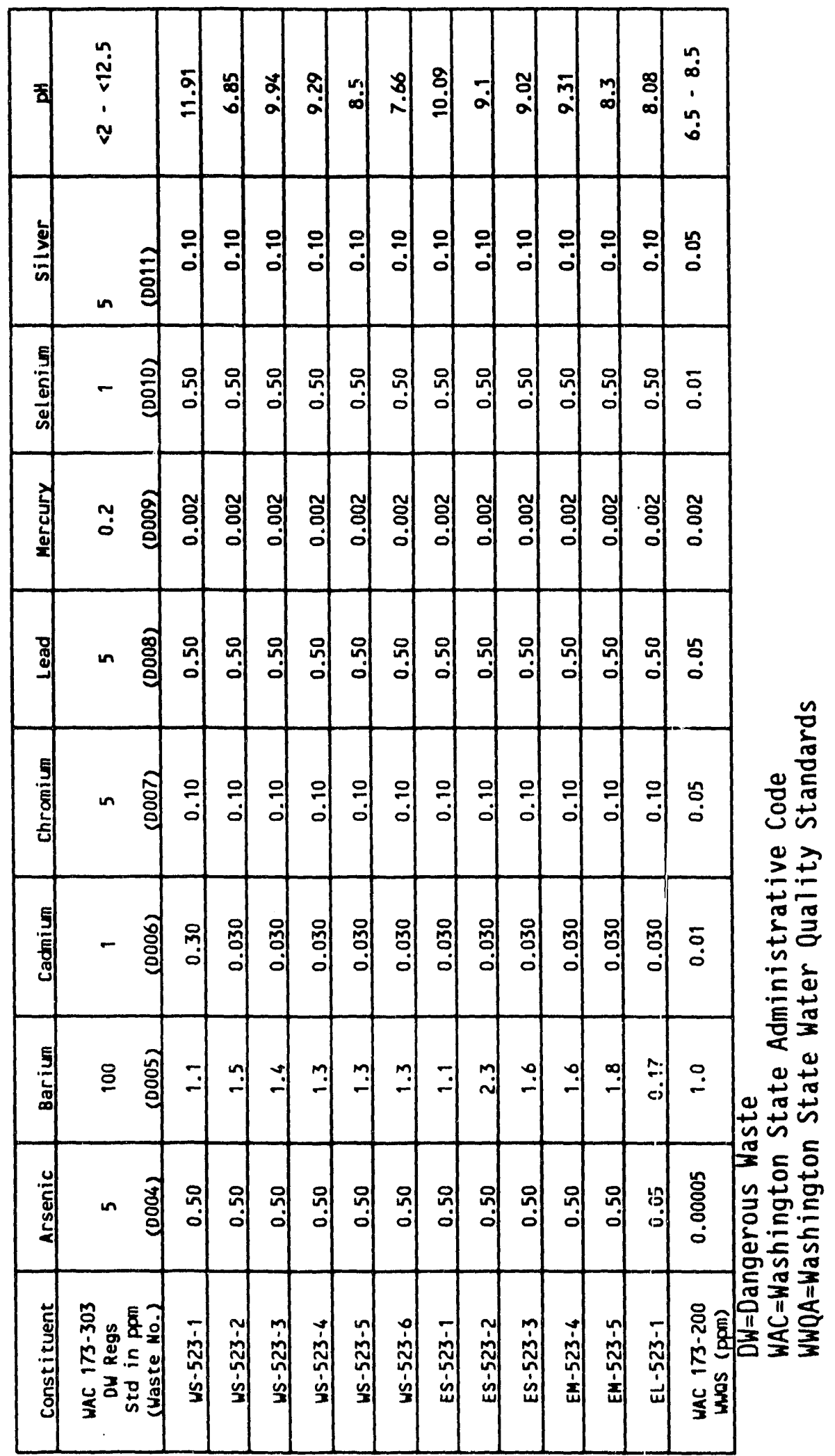


Table 3-7. 183-D Filter Backwash Wastewater Summary (adapted from WHC 1990C). (sheet 1 of 2)

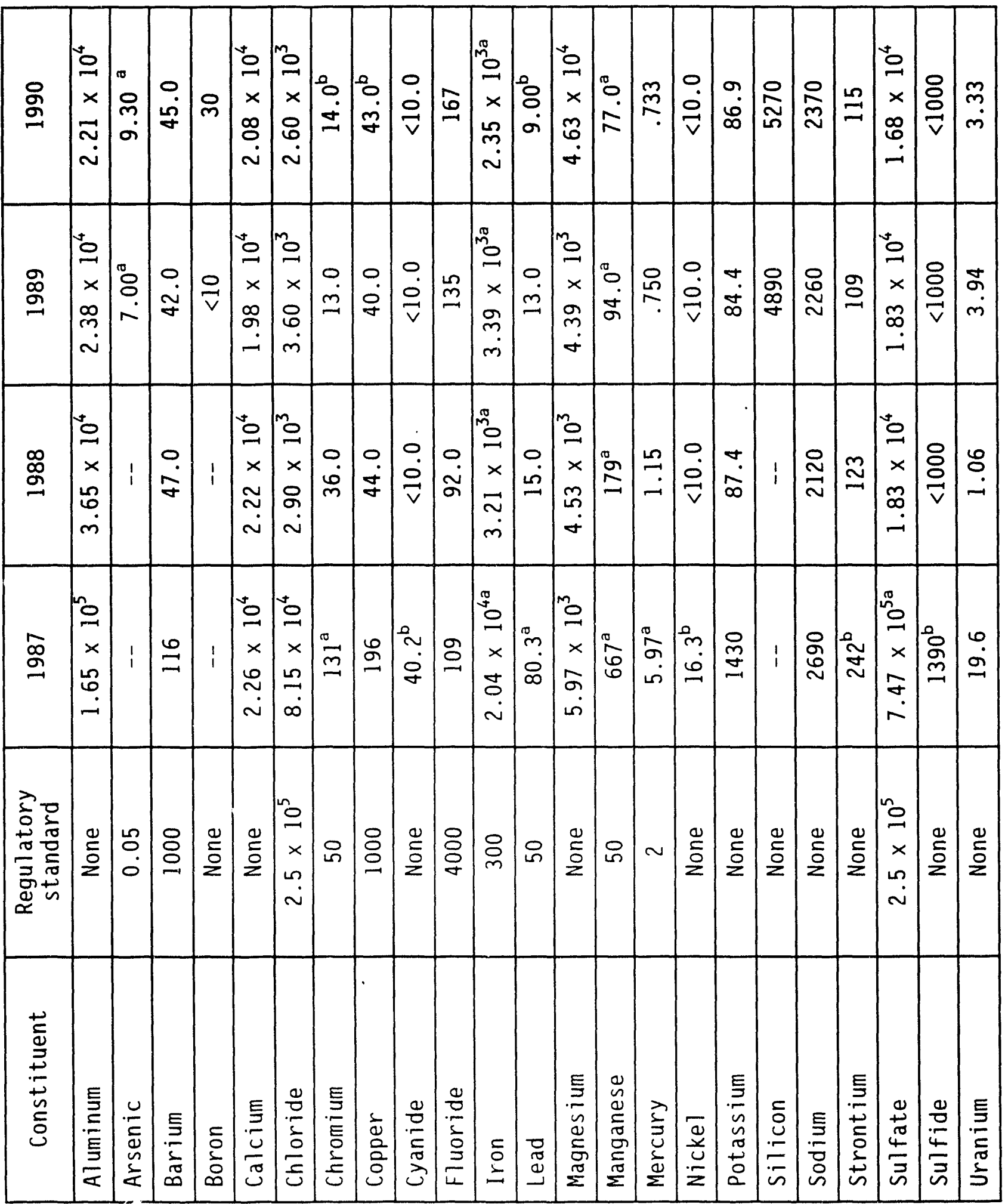


Table 3-7. 183-D Filter Backwash Wastewater Summary (adapted from WHC 1990C). (sheet 2 of 2)

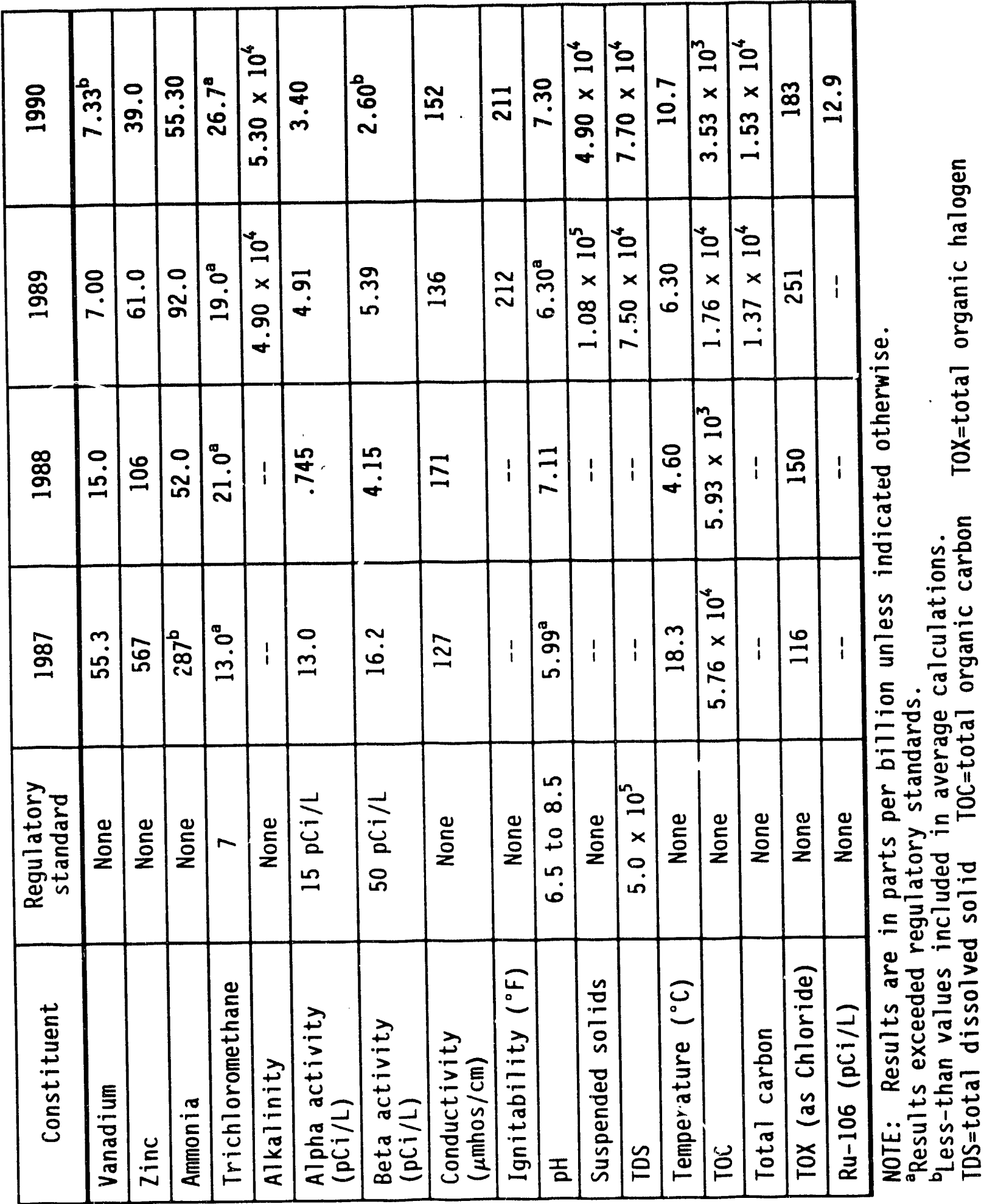


WHC-EP-0666

\subsection{CONCEPTUAL MODEL OF HYDROLOGIC RESPONSE AND CONTAMINANT MIGRATION}

\subsection{HYDROGEOLOGIC FRAMEWORK}

\subsubsection{Regional and Hanford Site Geology}

The Pasco Basin and the Hanford Site are underlain by pre-Miocene sedimentary and crystalline rocks (Campbell 1989), Miocene-aged (17.5 to $5 \mathrm{Ma}$ ) basalts of the Columbia River Basalt Group (Myers et al. 1979, Reidel and Fecht 1981, DOE 1988, Tolan et a1. 1989, Reidel et al. 1989, 1992) and interbedded sediments of the Ellensburg Formation (Reidel and Fecht 1981, DOE 1988, Smith 1988), and a Late Miocene to Holocene-aged (<8.5 Ma to present) suprabasalt sediment sequence (Myers et al. 1979; Tallman et al. 1981; DOE 1988; Smith et a1. 1989; Lindsey 1991a,1991b; Reidel et al. 1992).

4.1.1.1 Columbia River Basalt Group. The Columbia River Basalt Group is an assemblage of tholeiitic, continental flood basalts that cover an area of more that: $63,000 \mathrm{mi}^{2}\left(163,157 \mathrm{~km}^{2}\right)$ in Washington, Oregon, and Idaho and have an estimated volume of about $40,800 \mathrm{mi}^{3}\left(174,356 \mathrm{~km}^{3}\right.$ ) (DOE 1988, Reidel and Hooper 1989, Tolan et al. 1989). The Columbia River Basalt Group is divided, from oldest to youngest, into five formations: Imnaha Basalt, Picture Gorge Basalt, Grande Ronde Basalt, Wanapum Basalt, and Saddle Mountains Basalt (DOE 1988 Tolan et a1. 1989) (Figure 4-1). The Saddle Mountains Basalt (the uppermost basalt at the Hanford Site) is divided into (from oldest to youngest) the Umatilla, Wilbur Creek, Asotin, Esquatzel, Pomona, Elephant Mountain, and Ice Harbor Members (Reidel and Fecht 1981).

4.1.1.2 Ellensburg Formation. The Ellensburg Formation consists of volcaniclastic and silisiclastic deposits that occur between Columbia River Basalt Group basalt flows (DOE 1988; Smith 1988). At Hanford the three uppermost units of the Ellensburg Formation are, from oldest to youngest, the Selah interbed, the Rattlesnake Ridge interbed, and the Levy interbed. A detailed discussion of the Ellensburg Formation at the Hanford Site is given in Reidel and Fecht (1981). Smith (1988) and Smith et a1. (1989) discuss the Ellensburg Formation and correlative units throughout the regior..

4.1.1.3 Suprabasalt Sediments. Discussions of various aspects of suprabasalt sediment geology are found in Myers et al. (1979), Tallman et al. (1979, 1981), PSPL (1982), Bjornstad (1984), Fecht et al. (1987), DOE (1988), Baker et al. (1989), Smith et al. (1989), Deianey et al. (1991), Lindsey (1991a, 1992), Lindsey et al. (1991), and Reidel et al. (1992). Delaney et al. (1991), Lindsey (1991a), and Reidel et al. (1992) provide the most recent synopsis of suprabasalt sediment geology for the Hanford Site. The following discussion is summarized from these recent reports.

The suprabasalt sedimentary sequence (Figure 4-2) is up to $750 \mathrm{ft}(229 \mathrm{~m})$ thick at the Hanford Site. It is dominated by the laterally extensive late Miocene to Pliocene Ringold Formation and the Pleistocene Hanford formation. Laterally discontinuous units, referred to as the Plio-Pleistocene unit, early "Paiouse": soii, and pre-inissuuid gravels, separate the Haniford formation and Ringold Formation locally. Holocene-aged alluvial and eolian deposits cap the suprabasalt sequence. 
4.1.1.3.1 Ringold Formation. The Ringold Formation is up to $600 \mathrm{ft}$ (183 m) thick within the Pasco Basin; it pinches out against basalt ridges around the edge of and within the basin; and it consists of semi-indurated clay, silt, fine- to coarse-grained sand, and pebble to cobble gravel. Ringold deposits are grouped into five sediment facies associations (fluvial gravel, fluvial sand, overbank-paleosol, lacustrine, basaltic alluvium) that are defined on the basis of lithology, petrology, stratification, and pedogenic alteration. The associations are summarized as follows:

1. Fluvial gravel--Consists of clast and lesser matrix-supported pebble to cobble gravel with a fine- to medium-grained sand matrix. Grain size distributions tend to be bimodal with granules and coarse-grained sand being rare. Crude to well-defined stratification and low angle, lenticular bedding geometries generally dominate.

2. Fluvial sand--Fine- to coarse-grained quartzo-feldspathic sands displaying well-defined stratification dominate. Fining upwards packages less than one to several meters thick are common.

3. Overbank-paleosol--Laminated to massive silty sand, silt, and clay displaying evidence of pedogenic alteration dominates.

4. Lacustrine--Characterized by well-stratified clay with interbedded silt and silty sand.

5. Basaltic alluvium--Massive to crudely stratified, weathered to unweathered, basaltic pebble to cobble gravel, commonly with a mud-rich matrix dominates.

The distribution of facies associations within the Ririgold Formation forms the basis for stratigraphic subdivision (Lindsey 1991a, 1991b). The lower half of the Ringold Formation is characterized by fluvial gravel and sand- dominated intervals designated units $A, B, C, D$, and $E$ (Figure 4-3) that interfinger with fine-grained deposits typical of the overbank-paleosol and lacustrine facies associations. The lowest of these fine-grained intervals is designated the lower mud unit (see Figure 4-3). Interstratified deposits of the fluvial sand and overbank-paleosol facies associations and strata dominated by the lacustrine facies association form the upper half of the Ringold Formation (commonly referred to as the upper Ringold).

Several localized, informal units separate the Ringold Formation from the Hanford formation. These units are the (1) Plio-Pleistocene unit, (2) pre-Missoula gravels, and (3) early "Palouse" soil (see Figure 4-3) (Myers et al. 1979; Tallman et a1. 1979, 1981; DOE 1988; Reidel et al. 1992). The Plio-Pleistocene unit and early "Palouse" soil consist of loess, pedogenic calcium carbonate, and basaltic sands and gravels. Uncemented mixed lithology gravels with a quartzo-feldspathic matrix dominate the pre-Missoula gravels.

4.1.1.3.2 Hanford Formation. The Hanford formation consists of uncemented gravel, sand, and silt deposited by Pleistocene cataclysmic flood waters (Fecht et a1. 1987, DOE 1988, Baker et al. 1991). The Hanford formation is thickest in the vicinity of the 200 West and 200 East Areas where it can be up to $350 \mathrm{ft}(107 \mathrm{~m})$ thick. The Hanford formation is divided into three facies 
(gravel, sand, and silt dominated) that are gradational with each other. The facies are summarized as follows:

1. Grave1-dominated facies--Generally consist of cross stratified, coarsegrained sand and granule to boulder gravel that contain minor intercalated silt-rich horizons. These gravels generally are uncemented and matrix-poor, displaying an open-framework texture.

2. Sand-dominated facies--Well stratified, fine- to coarse-grained sand and granule gravel dominate. Silt content is variable, but where it is low an open-framework texture is common. Small pebbles and rip-up clasts in addition to lenticular, pebble-gravel interbeds, and silty interbeds may be present.

3. Silt-dominated facies--Interbedded silt and fine- to coarse-grained sand forming well-stratified normally graded rhythmites are characteristic.

In addition to the three facies, clastic dikes also are commonly found in the Hanford formation as well as locally in other sedimentary units in the Pasco Basin (Black 1979). These clastic dikes are structures that generally cross-cut bedding, although they do locally parallel bedding. The dikes usually consist of thin, alternating vertical to subvertical layers of silt, sand, and granules. Where the dikes intersect the ground surface, a feature known as patterned ground can be observed.

4.1.1.4 Holocene Surficial Deposits. Holocene surficial deposits consist of silt, sand, and gravel that form a thin (<16 ft $[4.9 \mathrm{~m}]$ ) veneer across much of the Hanford Site. These sediments were deposited by a mix of eolian and alluvial processes.

4.1.1.5 Structural Geology. The Columbia Plateau is divided into three informal structural subprovinces: Blue Mouritains, Palouse, and Yakima Fold Belt (Reidel et al. 1989, Tolan and Reidel 1989). These structural

subprovinces are delineated on the basis of their structural fabric. The Hanford Site is located in the eastern Yakima Fold Belt near its junction with the Palouse subprovince.

The Yakima Fold Belt consists of a series of segmented, narrow, asymmetric, and generally east-west trending anticlines that separate broad, low amplitude structural basins (Reidel 1984, Reidel et al. 1989). The Pasco Basin (where the Hanford Site is situated) is one of the largest structural basins within the Yakima Fold Belt. The Pasco Basin is bounded on the north by the Saddle Mountains anticline, on the west by the Hog Ranch-Naneum Ridge anticline, and on the south by the Rattlesnake Mountain anticline. The Palouse slope, a west-dipping monocline, bounds the Pasco Basin on the east. The Pasco Basin is divided into the Wahluke and Cold Creek synclines by the Gable Mountain anticline, the easternmost extension of the Umtanum Ridge anticline.

\subsubsection{0-D Area Geology}

The 100-D Area geology is illustrated in a generaized straligraphic column (Figure 4-4). Stratigraphic data specific to the 100-D Area are only 
available down to the upper units of the Ringold Formation. Data on deeper units are derived from deeper boreholes in nearby areas (100-N and 100-H) . Most of the data on the upper units were derived from recently installed monitoring wells, including four around the 100-D Ponds (DOE-RL 1993a).

4.1.2.1 Columbia River Basalt Group. The uppermost unit of the Columbia River Basalt Group in the 100-D Area is the Elephant Mountain Member of the Saddle Mountains Basalt. This unit underlies the entire "horn" area of the Hanford Reach and dips gently to the south toward the axis of the Wahluke syncline (Lindsey and Jaeger 1993). The contact between the Columbia Basin Basalt Group and the Ringold Formation lies at an elevation of 0 to $50 \mathrm{ft}$ ( 0 to $15 \mathrm{~m}$ ) above sea level (DOE-RL 1993a). Only two boreholes (199-H-2 and 199-H4-15C) in the "horn" area penetrate to the Elephant Mountain Member, so little data are available for descriptive purposes (Lindsey and Jaeger 1993).

4.1.2.2 Ellensburg Formation. Only one of the two boreholes (199-H4-2) mentioned above goes deep enough to intersect sediments that are believed to be part of the Rattlesnake Ridge interbed of the Ellensburg Formation. Descriptions of the unit are 1 imited, but it appears to consist of interbedded tuff, paleosols, and fluvial sands and gravels (Lindsey and Jaeger 1993).

\subsubsection{Suprabasalt Sediments.}

4.1.2.3.1 Ringold Formation. The top of the Ringold Formation is encountered between 129 and $109 \mathrm{~m}$ ( 422 and $358 \mathrm{ft}$ ) above sea level (45 to 90 $\mathrm{ft}$ [14 to $28 \mathrm{~m}$ ] below the surface) in the 100-D Area (Figure 4-5). Throughout most of the 100-D Area, the top of the Ringold Formation consists of the fluvial gravels of unit $E$. However, along the northern and eastern boundaries of the area, these gravels are absent, and the top of the Ringold consists of muds that underlie unit $E$. The distribution of unit $E$ is related to both Ringold depositional trends and post-Ringold erosion (Lindsey and Jaeger 1993). The muds underlying unit $E$ are dominated by the overbank-paleosol facies association. The top of this sequence is irregular, being highest in the north-central and southeastern parts of the area. From this high, the contact slopes to the north, northeast, and west. It is not clear from boreholes in the vicinity of the 100-0 Area if the contact also slopes to the south and southeast. However, interpretations presented by Lindsey (1992), indicate the top of these muds slope to the south towards the axis of the Wahluke syncline. Where the muds are overlain by Hanford formation deposits, the contact is erosional. Where the Ringold gravels overlie the muds, the contact reflects both erosion and structure (Lindsey and Jaeger 1993). The total thickness of the Ringold Formation is approximately 300 to $400 \mathrm{ft}$ (90 to $120 \mathrm{~m}$ ) (DOE-RL 1993a).

4.1.2.3.2 Hanford Formation. The Hanford formation in the 100-D Area consists of sand and minor silt and gravel typical of the sand-dominated facies and pebble-cobble gravel typical of the gravel-dominated facies (Lindsey and Jaeger 1993). Throughout most of the area, the upper one-half to two-thirds of the Hanford formation is characterized by interbedded strata typical of both facies (see Figures 4-4 and 4-5). Studies of inferred outcrop analogues suggest these interbedded strata consist of sand-rich horizons that locally may be pebble-rich alternating with pebble to cobble gravel horizons. The scale of interbodding usually is on the order of a less than 3 to $10 \mathrm{ft}$ $(<j \mathrm{~m})$. Pebble-cobble gravel deposits with few, if any, sand and silt 
interbeds comprise the lower 10 to $20 \mathrm{ft}(3$ to $6 \mathrm{~m}$ ) of the Hanford formation. The Hanford formation disconformably overlies either the fluvial graveldominated or overbank/paleosol-dominated strata of the Ringold Formation (Lindsey and Jaeger 1993).

The Hanford formation is 40 to $50 \mathrm{ft}(12$ to $15 \mathrm{~m}$ ) thick throughout the 100-D Area except 1ocally where it has been excavated (see Figures 4-4 and 4-5). Where excavation has occurred, a few feet to several tens of feet (a meter to several meters) of the unit have been removed. In the area of the 100-D Ponds, the entire unit appears to have been removed in the vicinity of borehole 199-D8-6 (Lindsey and Jaeger 1993). In boreholes 199-08-4, -5, and 199-D5-13, there is a small part of the Hanford formation beneath the backfill (coal ash) (Hartman 1992).

4.1.2.4 Holocene Surficial Deposits. Holocene deposits in the vicinity of the 100-D Area consist of Columbia River overbank sediments and eolian deposits. North of 100-D (downstream), Holocene river deposits are common. These deposits are concentrated between the river and the $400-\mathrm{ft}(122-\mathrm{m})$ contour and are found in a series of abandoned and intermittently active channels. Localized accumulations of overbank deposits filling topographic depressions also may be found above these channels. Eolian deposits consisting of fine- to medium-grained sand form a thin (usually $<5 \mathrm{ft}[<2 \mathrm{~m}]$ thick), discontinuous layer across much of the area (Lindsey and Jaeger 1993).

4.1.2.5 Backfill. Backfill occurs locally throughout the 100-D Area. The backfill is dominantly composed of power plant coal ash. The coal ash can be characterized as angular to subangular grains, ranging in size from medium sand to small pebble. This material does not contain any significant cementation, commonly being loose and friable in the pit face at the 100-D Ponds. The largest accumulation of backfill in the 100-D Area is found in the vicinity of the 100-D Ponds, in boreholes 199-D8-4, -5, -6, and 199-D513 (see Figures 4-4 and 4-5) (DOE-RL 1993a). At this location, the backfill is as much as $65 \mathrm{ft}(20 \mathrm{~m})$ thick and the bulk of or entire Hanford formation has been removed by excavation (Lindsey and Jaeger 1993).

The 100-D Ponds were constructed within the boundaries of what was formerly the 188-D (Coal) Ash Disposal Basin. Before construction of the ponds, an unknown quantity of coal ash from the powerhouse boilers in $D$ Area was flushed out to this location using raw Columbia River water. This practice occurred from 1950 until 1968, when the powerhouse was decommissioned (D0E-RL 1993a).

\subsubsection{Regional and Hanford Site Hydrology}

4.1.3.1 Surface Water. Surface drainage enters the Pasco Basin from several other basins, which include the Yakima River Basin, Horse Heaven Basin, Walla Walla River Basin, Palouse/Snake Basin, and Big Bend Basin (Figure 4-6) (DOE 1988). Within the Pasco Basin, the Columbia River is joined by major tributaries including the Yakima. Snake, and Walla Walla Rivers. No perennial streams originate within the Pasco Basin. Columbia River inflow to the Pasco Basin is recorded at the United States Geological Survey (USGS) gauge below Priest Rapids Dam, and outflow is recorded below McNary Dam. Average annual flow at these recording stations is approximateiy $8.7 \times 10^{?}$ acre-fi 
$\left(1.1 \times 10^{11} \mathrm{~m}^{3}\right)$ at the USGS gauge and $1.3 \times 10^{8}$ acre-ft $\left(3.9 \times 10^{6} \mathrm{~m}^{3}\right)$ at the McNary Dam gauge (DOE 1988).

Total estimated precipitation over the basin averages less than $6.2 \mathrm{in} . / \mathrm{yr}(15.8 \mathrm{~cm} / \mathrm{yr})$. Mean annual runoff from the basin is estimated to be
less than $1.1 \times 10^{9} \mathrm{ft}^{3} / \mathrm{yr}\left(3.1 \times 10^{7} \mathrm{~m}^{3} / \mathrm{yr}\right)$, or approximately $3 \%$ of the total precipitation. The remaining precipitation is assumed to be lost through evapotranspiration with a small component (perhaps less than $1 \%$ ) recharging the groundwater system (DOE 1988).

Primary surface water features associated with the Hanford Site are the Columbia River and its major tributaries and the Yakima River. West Lake, about 10 acres $\left(40,470 \mathrm{~m}^{2}\right)$ in size and 1 ess than $3 \mathrm{ft}(1 \mathrm{~m})$ deep, is the only natural lake within the Hanford Site (DOE 1988). Wastewater ponds, cribs, and ditches associated with nuclear fuel processing and waste disposal activities are also present on the Site (Figure 4-7).

The Columbia River flows through the northern part of the Hanford Site and along the eastern border of the Site. This section of river, the Hanford Reach, extends from Priest Rapids Dam to the headwaters of Lake Wallula (the reservoir behind McNary Dam). Flow along the Hanford Reach is controlled by Priest Rapids Dam. Several drains and intakes are also present along this reach, including irrigation outfalls from the Columbia Basin Irrigation Project, the Washington Public Power Supply System Nuclear Project No. 2 intakes, and Hanford Site intakes for onsite water use.

Routine water-quality monitoring of the Columbia River is conducted by DOE for both radiological and nonradiological parameters and has been reported by Pacific Northwest Laboratory since 1973. Ecology has issued a Class A (excellent) quality designation for Columbia River water along the Hanford Reach from Grand Coulee Dam, through the Pasco Basin, to McNary Dam. This designation requires that all industrial uses of this water be compatible with other uses, including drinking, wildlife habitat, and recreation. In general, the Columbia River water is characterized by a very low suspended load, a low nutrient content, and an absence of microbial contaminants (DOE 1988).

Approximately one-third of the Hanford Site is drained by the Yakima River system. Cold Creek and its tributary, Dry Creek, are ephemeral streams within the Yakima River drainage system. Both streams drain areas along the western part of the Hanford Site and cross the southwestern part of the Site toward the Yakima River. Surface flow, which may occur during spring runoff or after heavier-than-normal precipitation, infiltrates and disappears into the surface sediments. Rattlesnake Springs, located on the western part of the site, forms a smail surface stream that flows for about $2.9 \mathrm{~km}$ (1.8 mi) before infiltrating into the ground.

4.1.3.2 Groundwater. (Information in this section is summarized from Delaney et al. 1991). The hydrogeology of the Pasco Basin is characterized by a multiaquifer system that consists of four hydrogeologic units that correspond to the upper three formations of the Columbia River Basalt Group (Grande Ronde Basalt, Wanapum Basalt, and Saddle Mountains Basalt) and the suprabasalt sediments. Thu basalt aquifers consist of the tholeitic flood basalts of the Columbia River Basalt Group and relatively minor amounts of intercalated fluvial and volcaniclastic sediments of the Eilensburg Formation. Confined 
zones in the basalt aquifers are present in the sedimentary interbeds and/or interflow zones that occur between dense basalt flows. The main water-bearing portions of the interflow zones are networks of interconnecting vesicles and fractures of the flow tops and flow bottoms (DOE 1988). The suprabasalt sediment or uppermost aquifer system consists of fluvial, lacustrine, and glaciofluvial sediments. This aquifer is regionally unconfined and is contained largely within the Ringold Formation and Hanford formation. Table 4-1 presents hydraulic parameters for various water-bearing geologic units at the Hanford Site.

Local recharge to the shallow basalt aquifers results from infiltration of precipitation and runoff along the margins of the Pasco Basin and in areas of artificial recharge where a downward gradient from the unconfined aquifer system to the uppermost confined basalt aquifer may occur. Regional recharge of the deep basalt aquifers is inferred to result from interbasin groundwater movement originating northeast and northwest of the Pasco Basin in areas where the Wanapum and Grande Ronde Basalts crop out extensively (DOE 1988). Groundwater discharge from shallow basalt aquifers is probably to the overlying aquifers and to the Columbia River. The discharge area(s) for the deeper groundwater system is uncertain, but flow is inferred to be generally southeastward with discharge thought to be south of the Hanford Site (DOE 1988).

Erosional "windows" through dense basalt flow interiors allow direct interconnection between the uppermost aquifer system and underlying confined basalt aquifers. Graham et a1. (1984) reported that some contamination was present in the uppermost confined aquifer (Rattlesnake Ridge interbed) south and east of Gable Mountain Pond. Graham et a1. (1984) evaluated the hydrologic relationships between the Rattlesnake Ridge interbed aquifer and the unconfined aquifer in this area and delineated a potential area of intercommunication beneath the northeast portion of the 200 East Area.

The uppermost aquifer system is regionally unconfined beneath the Hanford Site and lies at depths ranging from less than $1 \mathrm{ft}(0.3 \mathrm{~m})$ below ground surface near West Lake and the Columbia and Yakima Rivers to greater than 350 $\mathrm{ft}(107 \mathrm{~m})$ in the central portion of the Cold Creek syncline. Groundwater in this aquifer system occurs within the glaciofluvial sands and gravels of the Hanford formation and the fluvial/lacustrine sediments of the Ringold Formation. Ringold sediments are divided into five lithofacies: (1) fluvial gravel, (2) fluvial sand, (3) overbank deposits consisting of silt and sand, (4) lacustrine deposits, and (5) basaltic debris flow gravel.

The position of the water table in the southwestern Pasco Basin is generally within Ringold fluvial gravels of unit FSE. In the northern and eastern Pasco Basin the water table is generally within the Hanford formation. Hydraulic conductivities for the Hanford formation $(2,000$ to $10,000 \mathrm{ft} / \mathrm{d}$ [610 to $3048 \mathrm{~m} / \mathrm{d}]$ ) are much greater than those of the gravel facies of the Ringold Formation (610 to $3,050 \mathrm{ft} / \mathrm{d}$ [186 to $930 \mathrm{~m} / \mathrm{d}]$ ) (Graham et al. 1981). The main body of the unconfined aquifer generally occurs within the Ringold Formation.

The base of the uppermost aquifer system is defined as the top of the uppermost basalt flow. However, fine-grained overbank and lacustrine deposits in the Ringold Formation locally form confining layers for Ringold fluvial 
gravels (units FSA, FSB, FSD1, FSC) underlying unit FSE. The uppermost aquifer system is bounded laterally by anticlinal basalt ridges and is approximately $500 \mathrm{ft}(152 \mathrm{~m})$ thick near the center of the Pasco Basin.

Sources of natural recharge to the uppermost aquifer system are rainfall and runoff from the higher bordering elevations, water infiltrating from small ephemeral streams, and river water along influent reaches of the Yakima and Columbia Rivers. The movement of precipitation through the unsaturated (vadose) zone has been studied at several locations on the Hanford Site (Gee 1987, Routson and Johnson 1990, Rockhold et al. 1990). Conclusions from these studies vary. Gee (1987) and Routson and Johnson (1990) concluded that no downward percolation of precipitation occurs on the 200 Area Plateau where the sediments are layered and vary in texture, and that all moisture penetrating the soil is removed by evapotranspiration. Rockhold et a1. (1990) suggested that downward water movement below the root zone is common in the 300 Area, where soils are coarse textured and precipitation was above normal.

Artificial recharge of the uppermost aquifer system occurs from the disposal of large volumes of wastewater on the Hanford Site (principally in the 200 Areas), and from large irrigation projects surrounding the Hanford Site. Figures 4-8 and 4-9 illustrate the groundwater table for the Hanford Site during the periods January 1944 and June 1989. Effluent disposal at the Hanford Site altered these hydraulic gradients and flow directions. Before operations at the Hanford Site began in 1944, the hydraulic gradient in all but the southwestern-most portion of the Hanford Site was approximately $5 \mathrm{ft} / \mathrm{mi}(1.5 \mathrm{~m} / \mathrm{km})$. Regional groundwater flow was generally toward the eastnortheast, although flow north of Gable Mountain was more to the north. Groundwater flow north of Gable Mountain now trends in a more northeasterly direction as a result of mounding near reactors and flow through Gable Gap. South of Gable Mountain, flow is interrupted locally by the groundwater mounds in the 200 Areas. There is also a component of groundwater flow to the north between Gable Mountain and Gable Butte from the 200 Areas.

Wastewaters discharged on the Hanford Site have reached the unconfined aquifer and the confined aquifer of the Rattlesnake Ridge interbed. The primary constituents that have reached the upper confined aquifer and the uppermost aquifer system are tritium, iodine-129, ruthenium-106,

technetium-99, uranium, nitrate, and chromium (DOE 1987). The groundwater is routinely and extensively monitored to record the movement of contaminants and to determine any impact from the site to the public. Groundwater monitoring reports are produced annually (e.g., Serkowski and Jordan 1989).

Temporary reversal of groundwater flow entering the Columbia River may occur during transient, high-river stages. This occurrence is known as bank storage. Correlations were made between groundwater level and river-stage fluctuations along a $50-\mathrm{mi}(81-\mathrm{km})$ reach of the Columbia River adjacent to the Hanford Site by Newcomb and Brown (1961). They concluded that a $100-\mathrm{mi}^{2}$ $\left(260-\mathrm{km}^{2}\right)$ area within the Hanford Site was affected by bank storage. During a 45-day rise in river stage, it was estimated that water infiltrated at an average rate of $3,700 \mathrm{acre}-\mathrm{ft} / \mathrm{d}\left(111 \mathrm{~m}^{3} / \mathrm{d}\right)$ versus $1,000 \mathrm{acre}-\mathrm{ft} / \mathrm{d}\left(30 \mathrm{~m}^{3} / \mathrm{d}\right)$ during the 165-day recession period (time between consecutive storage events). Since this study was conducted, dam control on the Columbia River has reduced the magnitude of bank storage on the groundwater system. 


\subsubsection{0-D Area Hydrology}

There is very little site-specific hydrologic information available for the 100-D Area. There are fewer boreholes than in other 100 Areas and no deep boreholes. Information from surrounding areas (100-N and $100-\mathrm{H})$, can be used to extrapolate conditions in the 100-D Areas (Lindsey and Jaeger 1993, Hartman and Peterson 1992, Hartman 1991). A generalized stratigraphic column of the 100-D Area, including hydrologic units, is shown in Figure 4-4.

4.1.4.1 Vadose Zone. The vadose zone beneath the 100-D Area includes backfill, Holocene surficial deposits, the Hanford formation, and the uppermost portion of the Ringold Formation (see Figure 4-4). Not all of these units are present in all locations. The vadose zone ranges from 0 to $90 \mathrm{ft}$ (0 to $27 \mathrm{~m}$ ) thick (DOE-RL 1993a). In wells 199-D2-5, 199-D5-12, and 199-D8-3, this unit is 70 to $80 \mathrm{ft}(21$ to $24 \mathrm{~m})$ thick. The majority of the vadose zone lies within the gravels and lesser sands of the Hanford formation; the exception is in the area of the 100-D Ponds, where a thick accumulation of backfill (coal ash) is found (DOE-RL 1993a). Part of what is now the vadose zone was saturated when the 100-D groundwater mound was present in the 1960's (Hartman 1991). The only Ringold Formation strata found in the vadose zone are the fluvial gravel deposits of unit E (DOE-RL 1993a, Lindsey and Jaeger 1993, and Hartman 1991).

4.1.4.2 Uppermost Aquifer System. The first aquifer system beneath the 100-D Area is referred to as the uppermost aquifer system. This term refers to the entire saturated portion of the suprabasalt sediments (DOE-RL 1993a). This aquifer system is found almost entirely within the Ringold Formation and includes a series of confining and producing layers (aquitards and aquifers) (see Figure 4-4). The uppermost or suprabasalt aquifer system is underlain by the multilayered aquifer system found within the Columbia River Basalt Group (see Figure 4-4). Because of the lack of deep boreholes in the 100-D Area, the generalized hydrogeologic model for the uppermost and underlying aquifers shown in Figure 4-4 is extrapolated from deep boreholes el sewhere in the 100 Areas (Lindsey and Jaeger 1993, Hartman 1992, Hartman and Peterson 1992 , Hartman 1991).

- Unconfined (uppermost) aquifer--The hydrologic unit of primary importance to the 100-D Ponds groundwater impact assessment. This aquiter is 10 to $25 \mathrm{ft}(3$ to $8 \mathrm{~m})$ thick and is bounded on top by the water table and on the bottom by the shallowest confining unit (Ringold mud) (see Figures 4-4 and 4-5). The aquifer comprises partially cemented pebble to cobble gravel (Ringold Formation) with a sand matrix (DOE-RL 1993a, Hartman 1992, 1991). Slug tests in this aquifer yield hydraulic conductivities in the range of 3.9 to 130 $\mathrm{ft} / \mathrm{d}(1.2$ to $39.6 \mathrm{~m} / \mathrm{d})$ (Hartman 1992).

Water level measurements have been taken for every month in 1992 for wells in and near the 100-D Area as part of the RCRA monitoring program. The water table currently lies approximately $80 \mathrm{ft}(24 \mathrm{~m})$ beneath 1 and surface at the 100-D Ponds, within the Ringold Formation gravels (see Figure 4-4 and 4-5). Figure 4-10 shows the water table in the 100-D Area in June 1992. when the river stage was high. Groundwater flow is inferred to be to the northeast beneath the 100-D Ponds, approximately parallel to the Columbia River. The groundwater 
gradient in June was very low southwest of the ponds. The gradient to the northeast, between wells $199-08-4$ and -3 , was $1 \times 10^{-3}$. Figure 4-11 shows the water table in October of 1992, when the river stage and water table were lower. Groundwater flow is interpreted to be to the northwest (toward the river) beneath the 100-D Ponds in October and most of the rest of 1992. The groundwater gradient beneath the ponds in October was between $2 \times 10^{-3}$ and $3 \times 10^{-3}$ (DOE-RL 1993b). The normal direction of groundwater flow in the 100-D Area (when unaffected by artificial recharge and the changes in river stage), is towards the northwest and the river.

- Shallow/confining unit--A clay-rich unit composed of Ringold Formation overbank/paleosol muds is the confining unit underlying the unconfined aquifer. This unit appears to be continuous throughout the 100-D Area. The unit is approximately $50 \mathrm{ft}(15 \mathrm{~m})$ thick at well 199-D8-54B (the only well that completely penetrates this unit in the 100-D Area). No estimates of hydraulic conductivity are available for this unit (DOE-RL 1993a).

- Confined aquifer(s)--Well 199-D8-54B is completed in a $1.5 \mathrm{~m}$ - (5 ft-) thick silty sand unit in the Ringold Formation beneath the shallow confining unit. Data from boreholes near 100-N Area indicate that this is one of a series of thin aquifers and aquitards that extends down to the lower mud unit of the Ringold Formation. No estimates of aquifer properties are available for these units.

- Ringold lower mud confining layer--No boreholes in the 100-D Area reach the lower mud unit. Delaney et al. (1991) states that the vertical hydraulic conductivity of the lower mud is approximately $10^{-8}$ $\mathrm{ft} / \mathrm{d} \quad\left(3 \times 10^{-9} \mathrm{~m} / \mathrm{d}\right)$ in the $100-\mathrm{H}$ Area.

\subsection{HYDROLOGIC RESPONSES TO EFFLUENT DISPOSAL}

Effluent from filter backwashing is discharged in batches to the 100-D ponds approximately once a month. Additional effluent from basin washdown activities is discharged to the ponds twice a year. Occasionally, there appears to be some effect to the water table from the ponds when water table measurements were taken immediately after a discharge event (Figure 412). This particular figure illustrates the effects on the water table from a discharge of over $300,000 \mathrm{gal}(1,135,624 \mathrm{~L})$ to the ponds at one time. The event occurred when the settling basins inadvertently emptied in mid-January 1993. However, most of the time the changes to the water table are small, making it difficult to say if the effect is from discharges to the ponds or influence of the changes in river stage. The routine amounts and timing of the discharges are such that their effects on the water table are small compared to the effects from fluctuations in the water level of the Columbia River. Over the history of the ponds, there have been large volumes of water discharged to the unconfined aquifer, but the effects on the overall hydrologic system have been minimal. 
WHC-EP-0666

\subsection{GROUNDWATER QUALITY}

Parameters of concern in the 100 Areas are gross alpha, gross beta, tritium, nitrate, and hexavalent chromium. Plume maps have been generated for all of these contaminants. These contaminants are highly mobile in groundwater and were present in waste liquids and reactor coolant released in the 100 Areas. There is also evidence that points to migration of tritium from the 200 Areas northward through Gable Gap and towards the river. Several wells in the Gable Gap area and northward towards 100-K Area show elevated concentrations of tritium.

Hartman and Peterson (1992) present interpretations of groundwater chemistry for the 100-D Area based on data collected in 1990, before 18 new RCRA and Comprehensive Environmental Response Compensation and Liability Act of 1980 (CERCLA) monitoring wells were installed. At that time, their conclusions were that groundwater beneath most of the 100-D Area appeared to be contaminated by tritium, nitrate, and chromium. Data collected in 1992 from the RCRA and CERCLA monitoring wells indicate that the groundwater beneath the 100-D Ponds is less contaminated than the surrounding groundwater (Figures 4-13, 4-14, and 4-15). This distribution pattern appears to be the result of dilution caused by recharge from the 100-D Ponds (DOE-RL 1993b).

Most of the $\mathrm{pH}$ measurements taken at Wells 199-D8-4 and -6 were above the upper drinking water standard (8.5) (Figure 4-16a). The $\mathrm{pH}$ is higher in Wells 199-D8-4 and -6 than other wells farther away from the ponds. It is not clear at this time if the elevated $\mathrm{pH}$ values are due to current or past effluent discharges to the pond (DOE-RL 1993b). Effluent discharges in the past have tended to be below the lower drinking water standard (6.5), making the effluent slightly acidic. This effect would be neutralized when effluent comes into contact with the local sediments. Hanford surficial and nearsurface sediments would tend to buffer the solution and make it slightly alkaline. Also, the 100-D Ponds are built in the old 188-D (Coal) Ash Disposal Basin; coal ash is very alkaline and tends to significantly increase the $\mathrm{pH}$ of the groundwater in contact with it.

Specific conductance is lower at the wells nearest to the 100-D Ponds (199-D8-4 and -6) than at other nearby wells (Figure 4-16b). This relatively low specific conductance is probably caused by recharge to the unconfined aquifer from the 100-D Ponds effluent. Influx of Columbia River water during high river stages could also be contributing to the lower values in wells nearest the river. However, in Well 199-D8-5, which is nearer the river than Wel1s 199-08-4 and -6, this is not the case, as it has higher specific conductance values than the others (DOE-RL 1993b). Other wells in the area exhibit elevated specific conductance (Figure 4-17).

Total organic carbon (TOC) and total organic halogen (TOX) values were also available as part of the monitoring program. TOC values were less than $1,000 \mathrm{ppb}$. TOX values are under review for quality assurance reasons (DOE-RL 1993b).

Hydrochemical results for the groundwater monitoring wells at 100-D were compared to Hanford Site averages for the unconfined aquifer as a whole (Table 4-2), to determine if the 100-D and surrounding area unconfined aquifer differed in chemistry. All of the results are from samples collected in the 
1990's, with one exception: data from the 1980's were allso used for chloride to increase the size of the data set. The results of this comparison are as follows:

- Groundwater qual jty parameters (Table 4-3). The pH values for most of the wells monitored at 100-D and the surrounding area fall within the WWQS range of 6.5 to 8.5. Well 199-D8-3 has had $\mathrm{pH}$ values slightly above this range for 1991 and 1992. The RCRA monitoring wells for the 100-D Ponds tend to be on the high end of the range or slightly alkaline. The two wells completed in the coal ash have the higher values of the four, which is consistent with the observation that groundwater occurring in coal ash tends to be alkaline.

Specific conductivities in the RCRA monitoring wells are relatively low, in the 100 to $250 \mu \mathrm{mho} / \mathrm{cm}$ range. The effect of the effluent being discharged into the ponds is evident in these values. The effluent has a specific conductivity range of $12: 7$ to $171 \mu \mathrm{mhos} / \mathrm{cm}$, which is much lower than the unconfined aquifer $(\sim 360 \mu$ mhos $/ \mathrm{cm})$. When the effluent and groundwater mix, the wells nearer the pond should have specific conductance values that fall between the two ranges. In wells nearer the river, mixing of river water and groundwater can occur, also decreasing the specific conductivities.

Turbidity values for the RCRA wells are low, ranging from 0.4 to 3.9 nephelometric turbidity units (NTU) for 1992 and 0.6 to 2.8 NTU for 1993. The lowest value is at We11 199-D8-6, which is furthest upgradient. Wells $199-D-8-4$ and -5 have much higher values. This could be a result of the effects of the coal ash backfill in the area or because the wells are relatively new and the suspended solids have not been fully flushed from the well screen.

Alkalinity concentrations in the 100-D Area rarige from 47,500 to $116,000 \mathrm{ppb}$. The hardness ranges from 92,000 t:0 $140,000 \mathrm{ppb}$. The total dissolved solid (TDS) concentrations range from 312 to $627 \mathrm{ppb}$.

- Cation concentrations (Table 4-4). Calcium concentrations for the 100-D Area range from 21,000 to $101,000 \mathrm{ppb}$. Most of the concentrations are near the site average for the unconfined aquifer (See Table 4-2). The exceptions are lower values in the RCRA wells $(199-D 8-4,-5,-6)$ near the 100-D Ponds. The highest values are in wells near the old reactors and disposal facilities (Figure 4-18).

Potassium concentrations range from 1,970 to $7,770 \mathrm{ppb}$. Most of the values are slightly higher than the site average for the unconfined aquifer (see Table 4-2). The lowest values are in the RCRA wells near the ponds (199-D8-4, $-5,-6)$ and the upgradient RCRA well (199-D5-13). The highest values are in wells near the old reactors and disposal facilities (see Figure 4-18).

Sodium concentrations range from 500 to $20,700 \mathrm{ppb}$. Almost all of the values are higher than the site average for the unconfined aquifer (see Table 4-2). The exception is well 199-D5-13, the RCRA upgradient well, which shows the lowest concentration in the area. The next lowest values are in the RCRA wells near the ponds 
$(199-D 8-4,-5,-6)$. The highest values are in wells near the old reactors (see Figure 4-18).

- Anion concentrations (Table 4-5). Chloride concentrations for the 100-D Area range from 2,900 to $28,200 \mathrm{ppb}$. A 11 of the concentrations are well above the site average for the unconfined aquifer except those near the ponds (see Table 4-2). The wells that are highest in chloride are near the old reactors (see Figure 4-18). Elevated chloride concentrations may be from disposal of demineralizer regeneration wastes, which would be high in "NaCl."

Fluoride concentrations range from less than 100 to $610 \mathrm{ppb}$. Most of the concentrations are below the Site average for the unconfined aquifer (see Table 4-2). The lowest values are found in the RCRA wells (199-D8-4, -5, -6) near the 100-D Ponds and one well (199-D519) which is upgradient of the old reactors (see Figure 4-18). The highest values are in wells near the old reactors and disposal facilities (see Figure 4-18).

Nitrate concentrations range from 700 to $21,000 \mathrm{ppb}$. A11 of the concentrations are above the Site average for the unconfined aquifer (see Table 4-2). The lowest values are found in the RCRA wells (199D8-4, -5, -6) near the 100-D Porids and one well (199-D5-20) located east of the 100-D Ponds near the river (see Figure 4-18). The highest values are in wells near the old reactors and disposal facilities (see Figure 4-18). There is a nitrate plume in the 100-D Area from past-practice disposal activities (see Figure 4-15).

Nitrite concentrations are less than the contractually required quantification limit (CQRL) of $200 \mathrm{ppb}$ for the RCRA wells and $100 \mathrm{ppb}$ for the CERCLA wells, in all but two of the wells sampled. The two wells with reportable concentrations are 199-D5-13 with $375 \mathrm{ppb}$ and 199-D8-3 with $700 \mathrm{ppb}$.

Phosphate concentrations range from less than the CQRL (400 ppb) to $800 \mathrm{ppb}$. The RCRA wells all have concentrations less than the CQRL. The other wells monitored fall in the 600- to 800-ppb range. These concentrations are below the site average for the unconfined aquifer (see Table 4-2).

Sulfate concentrations range from 11,800 to $94,500 \mathrm{ppb}$. Half of the wells have concentrations above the Site average for the unconfined aquifer (see Table 4-2). Of the remaining wells, most are close to the Site average. The lowest values are found in the two wells (199D2-5, -6) located upgradient of most of the facilities (see Figure 4-18): The highest values are in wells near the old reactors and disposal facilities (see Figure 4-18). The RCRA wells near the 100-D Ponds (199-D8-4, -6) are near the Site average. Well 199-D8-5, which is downgradient, shows elevated concentrations. The pond effluent is close to the site average values, so it is not the cause of any of the elevated values seen in the area.

Sulfide concentrations are around $1 \mathrm{ppb}$ in the wells in the area. 
- Metal concentrations-unfiltered (Table 4-60). Antimony concentrations are less than the CQRL (200 ppb) in the RCRA wells. The other wells have concentrations that range from 16 to $31 \mathrm{ppb}$.

Arsenic concentrations are less than the CQRL $(5.0 \mathrm{ppb})$ in the RCRA wells. The other wells range in concentration from 2 to $5 \mathrm{ppb}$. These concentrations are below or near the site average for the unconfined aquifer, which is approximately $5 \mathrm{ppb}$.

Barium concentrations range from less than 20 to $122 \mathrm{ppb}$. All but two of the wells have concentrations above the site average for the unconfined aquifer (see Table 4-2). The lowest values are found in the RCRA wells (199-D8-4, -5) near the 100-D Ponds. The highest values are in wells near the old reactors (see Figure 4-18). None of the wells exceed the WWQS for barium $(1,000 \mathrm{ppb})$.

Beryllium concentrations are less than the CQRL ( $3.0 \mathrm{ppb})$ in the RCRA wells. The other wells have concentrations that range from 0.7 to $0.9 \mathrm{ppb}$. Beryllium is present only in trace concentrations in wells where it was detected.

Cadmium concentrations are less than the CQRL (10 ppb) in the RCRA wells. Concentrations range from 2 to $3 \mathrm{ppb}$ in the other wells. Cadmium is present only in trace concentrations in wells where it was detected.

Cobalt concentrations are less than the CQRL (20 ppb) in the RCRA wells. The concentrations range from 3 to $5 \mathrm{ppb}$ in the other wells. Cobalt is present only in trace concentrations in wells where it was detected.

Chromium concentrations range from 28 to $1,920 \mathrm{ppb}$. All but two of the wells have concentrations above the Site average for the unconfined aquifer (see Table 4-2) and exceed the WWQS for chromium $(50 \mathrm{ppb})$. The lowest values are found in the RCRA wells (199-D8-4, and -5 ) near the 100-D Ponds. Chromium concentrations can be elevated in unfiltered samples from new wells due to influence of the stainless steel casing and well screen. There is a chromium plume (see Figure 4-14) in the 100-D Area from past-practice operations in the area.

Copper concentrations are less than the CQRL (20 ppb) in the RCRA wells. The concentrations range from 3 to $12 \mathrm{ppb}$ in the other wells. These values are all below the Site average for the unconfined aquifer (see Table 4-2).

Iron concentrations range from 60 to $4,833 \mathrm{ppb}$. Half of the wells have concentrations above the Site average for the unconfined aquifer (see Table 4-2) and exceed the WWQS for iron (300 ppb). The lowest values are found in wells (199-D8-3, and -5) on the northeast corner of the 100-D Area and near the 100-D Ponds, respectively. The highest values are in wells near the old reactors (see Figure 4-18). Iron concentrations can be elevated in unfiltered samples from new 
wells as a result of the ir luence of stainless steel casing and well screen.

Magnesium concentrations, inge from 1,110 to $26,700 \mathrm{ppb}$. Half of the wells have concentrations above the site average for the unconfined aquifer (see Table 4-2). The lowest values are found in wells (199-D2-6, 199-D8-4, -6, and 199-D8-3) on the southwest corner of the 100-D Area, near the 100-D Ponds, and in the northeast corner of the area, respectively. The other two wells are likely unaffected because of their location at the edges of the area. The highest values are in wells near the old reactors (see Figure 4-18). The high magnesium concentrations may be a result of past-practice disposal activities in the area.

Mar yanese concentrations range from 3 to $253 \mathrm{ppb}$. Some of the wells have concentrations ajove the Site average for the unconfined aquifer (see Table 4-2) and three exceed the WWQS for manganese (50 ppb). The lowest values are found in wells (199-D8-3 and 199-D5-12) on the northeast corner of the of the 100-D Area and nea" the old reactors on the east side of the area, respectively. These two wells are likely unaffected because of their location at the edges of the area. The highesi values are in wells near and downgradient of the old reactors (see Figure 4-18). Wel1 199-D5-12 is upgradient of the reactors, which could be why it is unaffected. The high manganese concentrations may be a result of past-practice disposal activities in the area or localized reducing conditions (DOE-RL 1992a, 1992b, WHC 1990a).

Mercury concentrations are less than the CQRL $(0.2 \mathrm{ppb})$ in all but two of the wells. The two wells with detectable concentrations are 199-D5-13 and -15 . The concentrations are 0.33 and $0.62 \mathrm{ppb}$, respectively. These concentrations are below the WWQS for mercury (2 ppb). These wells are located southeast of the 100-D Ponds and jus $C$ north of D-Reactor, respertively (see Figure 4-18). The source of this mercury occurrence is uncertain at this time. Mercury is being investigated as part of the RCRA Closure Plan (DOE-RL 1993a) and the 100-HR-3 Operable Unit (DOE-RL 1992a).

Nickel concentrations range from 4 to $39 \mathrm{ppb}$. Many of the wells have concentrations slightly above the Site average for the unconfined aquifer (see Table 4-2). The lowest values are found in wells (199-D2-5 and 199-D5-12) on the southeast corner of the 100-D Area and near the old reactors on the east side of the area, respectively. These two wells are likely unaffected because of their location at the edges of the area. The highest values are in wells near and downgradient of the DR-Reactor (see Figure 4-18). Well 199-D5-12 is upgradient of the reactors, which may explain the lower nickel concentration. The slightly elevated nickel concentrations may be a result of past-practice disposal activities in the area.

Selenium concentrations are less than the CORL (10 ppb) in the RCRA wells. The other wells have concentrations that range from 4 to $12 \mathrm{ppb}$. Four wells exceed the WWQS for selenium (10 ppb); they are 199-D5-15, -19,-20. and 199-D8-3. These wells are located 
immediately north of the D-Reactor, on the northwestern edge of the 100-D Area near the river, and on the northeast corner of the area, respectively. The slightiy elevated selenium concentrations may be a result of past-practice disposal activities in the area.

Tin concentrations are less than the CQRL (10 ppb) in the RCRA wells. There are no data available for the other wells in the area.

Vanadium concentrations range from 6 to $18 \mathrm{ppb}$. The four RCRA wells had concentrations below the CQRL $(30 \mathrm{ppb})$. The highest concentrations of vanadium occur in a few wells near the old reactors (199-D5-14,-15,-19,-20, and 199-D8-3). With one exception, We11 199-05-14, these are the same wells that showed slightly elevated selenium concentrations. The slightly elevated vanadium concentrations may be a result of past-practice disposal activities in the area.

Zinc concenirations range from 9 to $112 \mathrm{ppb}$. The four RCRA wells had concentrations below the CQRL $(10 \mathrm{ppb})$. These values are consistent with the Site average values for zinc (see Table 4-2), except for two wells. Wells 199-D5-17 and -18 had concentrations of 112 and 43 ppb, respectively. These wells are located just north of the DR-Reactor building. These values are higher than the other wells in the area. The cause of these elevated values in relation to the other wells in the area is unknown.

- Radionuclide concentrations (Table 4-7). Gross alpha concentrations are near background levels in the 100-D Area. There does not appear to be any significant alpha contamination.

Gross beta concentrations range from 2.4 to $76 \mathrm{pCi} / \mathrm{L}$. The majority of the values are below $10 \mathrm{pC} \mathrm{i} / \mathrm{L}$. Only two wells exceed $10 \mathrm{pC} \mathrm{i} / \mathrm{L}$; they are 199-D8-3 and 199-D5-12, which are located in the northeast corner of the area and at the southeast corner of the D-Reactor building (see Figure 4-18). The values in these two wells correlate well with the strontium-90 results.

Cobalt-60 concentrations are near background levels in the 100-D Area. There does not appear to be any significant cobalt-60 contamination.

Cesium-137 concentrations are near background levels in the 100-D Area. There does not appear to be any significant cesium-137 contamination.

Strontium-90 concentrations range from negative values (actual result minus the background value) to $53 \mathrm{pCi} / \mathrm{L}$. Only two wells have values above "background:" they are 199-08-3 and 199-D5-12, which are located in the northeast corner of the area and at the southeast corner of the D-Reactor building (see Figure 4-18). The values in these two wells correlate well with the gross beta results. 
Technetium-99 concentrations are all less than the detection limit $(15 \mathrm{pCi} / \mathrm{L})$ in the 100-D Area. There does not appear to be any significant technetium-99 contamination.

Tritium concentrations range from 97 to $74,000 \mathrm{pCi} / \mathrm{L}$. The concentrations in the RCRA wells are at background in the two wells nearest the pond (199-D8-4, -6) and the lowest value in the area is at another RCRA we11 (199-08-5) (see Figure 4-18). A11 other wells show varying levels of tritium, with the highest being near the old reactors and disposal activities (see Figure 4-18). There is a tritium plume (see Figure 4-13) in the 100-D Area from past-practice operations in the area.

\subsection{SOIL COLUMN CHEMICAL FACTORS}

Sediment samples were recently taken in the 100-D Ponds as part of the 100-DR-1 Operable Unit sampling efforts. Three background samples were also taken of the coal ash at the site. The sediments have some elevated toxicity characteristic leaching procedure (TCLP) values for metals, but only barium and lead exceed drinking water standards. The higher detection limits for this test were appropriate for comparison with the WAC 173-303 (DW) criteria but not WAC 173-200 (WWQS) criteria. It is unknown whether the lead and arsenic exceeded drinking water standards because the detection limits used were too high for comparison of the data with the WWQS.

All of the elevated TCLP values for chromium, cadmium, and lead occurred in the settling pond sediments and were distributed throughout the areas sampled. Elevated values of barium were found in both ponds and again were distributed throughout the areas sampled.

It does not appear that leaching of heavy metals from the pond sediments is a major factor in potential groundwater contamination. A1! of the pond sediment leachate values for chromium and cadmium are below drinking water standards. Only one elevated lead value exceeded the drinking water standard. This value was from sediments near the settling pond influent pipe. Elevated values of barium above and just below the drinking water standards occurred in both pond sediments, although there is no discernable pattern to its distribution.

\subsection{SUMMARY OF CONCEPTUAL MODEL OF MOISTURE MOVEMENT AND CONTAMINANT TRANSPORT}

A hydrochemical conceptual model was developed to explain the groundwater monitoring results in the vicinity of the 100-D Ponds. Figure 4-19 illustrates the following discussion. The effluent entering the 100-D Ponds has low specific conductance $(<150 \mu$ mhos $/ \mathrm{cm})$, is slightly acidic pH (6.7), and is generally lower in concentration of most ions than the unconfined aquifer groundwater. The pond sediments consist of coal ash up to $65 \mathrm{ft}(20 \mathrm{~m})$ thick. The ash was sluiced out to the ponds as a slurry. When coal ash is "fresh" or unweathered, it has the following charactoristics: (1) it is enriched in heavy metals, (2) has an alkaline $\mathrm{pH}$ (9.5), and (3) is composed of unburned coal-carbon, periclase-MgO. lime-CaO. Fe oxides-magnetite, etc., minor 
sulfates, and $\alpha$-quartz (McCarthy and Groenewold 1983). When the pond effluent comes in contact with the fresh ash, the major initial reactions are as follows:

1. Formation of hydroxides

$$
\begin{aligned}
& \mathrm{CaO}+\mathrm{H}_{2} \mathrm{O}-\mathrm{Ca}(\mathrm{OH})_{2} \text { (portlandite) } \\
& \mathrm{MgO}+\mathrm{H}_{2} \mathrm{O}-\mathrm{Mg}(\mathrm{OH})_{2} \text { (brucite) }
\end{aligned}
$$

2. Formation of mobile metal oxyanions

$$
\mathrm{SeO}_{4}{ }^{2-}, \mathrm{CrO}_{4}{ }^{2-}, \mathrm{HAsO}_{4}{ }^{2-}, \mathrm{AsO}_{4}{ }^{3-}, \mathrm{SbO}_{4}{ }^{2-}, \mathrm{MoO}_{4}{ }^{2-} \text {, etc. }
$$

The mobile metal oxyanions are removed from the system by groundwater that flows into Columbia River. Over time, the portlandite and brucite flush down through the ash layer and into the sediments of the Ringold Formation that underlie the ash backfill. Here the portlandite and brucite undergo dissociation:

\section{Dissociation of hydroxides}

$$
\begin{aligned}
& \mathrm{Ca}(\mathrm{OH})_{2} \rightarrow \mathrm{Ca}^{2+}+2 \mathrm{OH}^{-} \\
& \mathrm{Mg}(\mathrm{OH})_{2} \rightarrow \mathrm{Mg}^{2+}+2 \mathrm{H}^{-}
\end{aligned}
$$

The continual dissolution and precipitation of portlandite and brucite supplies $\mathrm{OH}^{-}$ion to maintain the $\mathrm{pH}$ of the groundwater (just beneath and immediately downgradient of the ponds) in the 8.5 to 9 range. Surrounding groundwater $\mathrm{pH}$ values are in the 7 to 8 range.

Other continuing reactions within the system involve the formation of calcite- $\mathrm{CaCO}_{3}$, calcium bicarbonate- $\mathrm{Ca}\left(\mathrm{HCO}_{3}\right)_{2}$, and numerous $\mathrm{Al}-, \mathrm{Mg}-, \mathrm{Mn}-$, and Fe-hydroxy silicates. Less mobile metals fike $\mathrm{Zn}, \mathrm{Pb}, \mathrm{Cu}, \mathrm{Hg}$, and $\mathrm{Cd}$ would be trapped in the zone beneath the backfill. Portlandite and brucite, which form in the vadose zone beneath the ponds, are a continuing source of $\mathrm{OH}^{-}$ion and therefore alkaline $\mathrm{pH}_{2}$ values. In addition, there are sources of $\mathrm{HCO}_{3}^{-}$ (bicarbonate) and $\mathrm{CO}_{3}^{2-}$ (carbonate) within the soil column of the Ringold Formation. The alkaline carbonate zone created by these ions becomes, in effect, a "geochemical trap" for cationic heavy metals. Alkaline carbonate solution controls on heavy metal solubility and precipitation can be illustrated using cadmium as an example (Figure 4-20). This figure shows the basic reactions that would occur and the types of species that would form in an alkaline carbonate environment. Although this illustrates only the species for cadmium, similar reactions would occur for other cationic heavy metals $(\mathrm{Pb}, \mathrm{Zn}, \mathrm{Cu}$, and $\mathrm{Hg})$. 
The other major effect of the pond effluent is to add water of lower concentration (for most chemical parameters) into the ambient groundwater system. The monitoring results discussed in Section 4.3 illustrate this effect in several cases.

The conceptual model presented in this section is summarized as follows:

- Effluent with low concentrations for most chemical parameters and slightly acidic in $\mathrm{pH}$ is discharged to the 100-D Ponds.

- The effluent percolates through the backfill/ash and the water reacts with the lime and periclase in the ash to form hydroxides (e.g., portlandite and brucite).

- In the vadose zone beneath the backfill/ash, the hydroxides dissociate to $\mathrm{Ca}^{2+}, \mathrm{Mg}^{2+}$, and $\mathrm{OH}^{-}$, thereby raising the $\mathrm{pH}$ to a slightly alkaline range ( 8.5 to 9 ).

- $\mathrm{Fe}, \mathrm{Mn}, \mathrm{Mg}$, and $\mathrm{Al}$ form metal-hydroxysilicates, and less mobile metal cations ( $\mathrm{Cu}, \mathrm{Pb}, \mathrm{Zn}, \mathrm{Cd}$, and $\mathrm{Hg}$ ) form carbonates and hydroxides and are retained on the soil column.

- Mobile metal oxyanions (chromium, arsenic, antimony, molybdenum, and selenium) are rapidly flushed through the system.

- Concentrations of local contaminants are diluted by effluent discharge to the ponds. 
WHC-EP-0666 
Figure 4-1. Generalized Stratigraphy of the Pasco Basin and Surrounding Area.

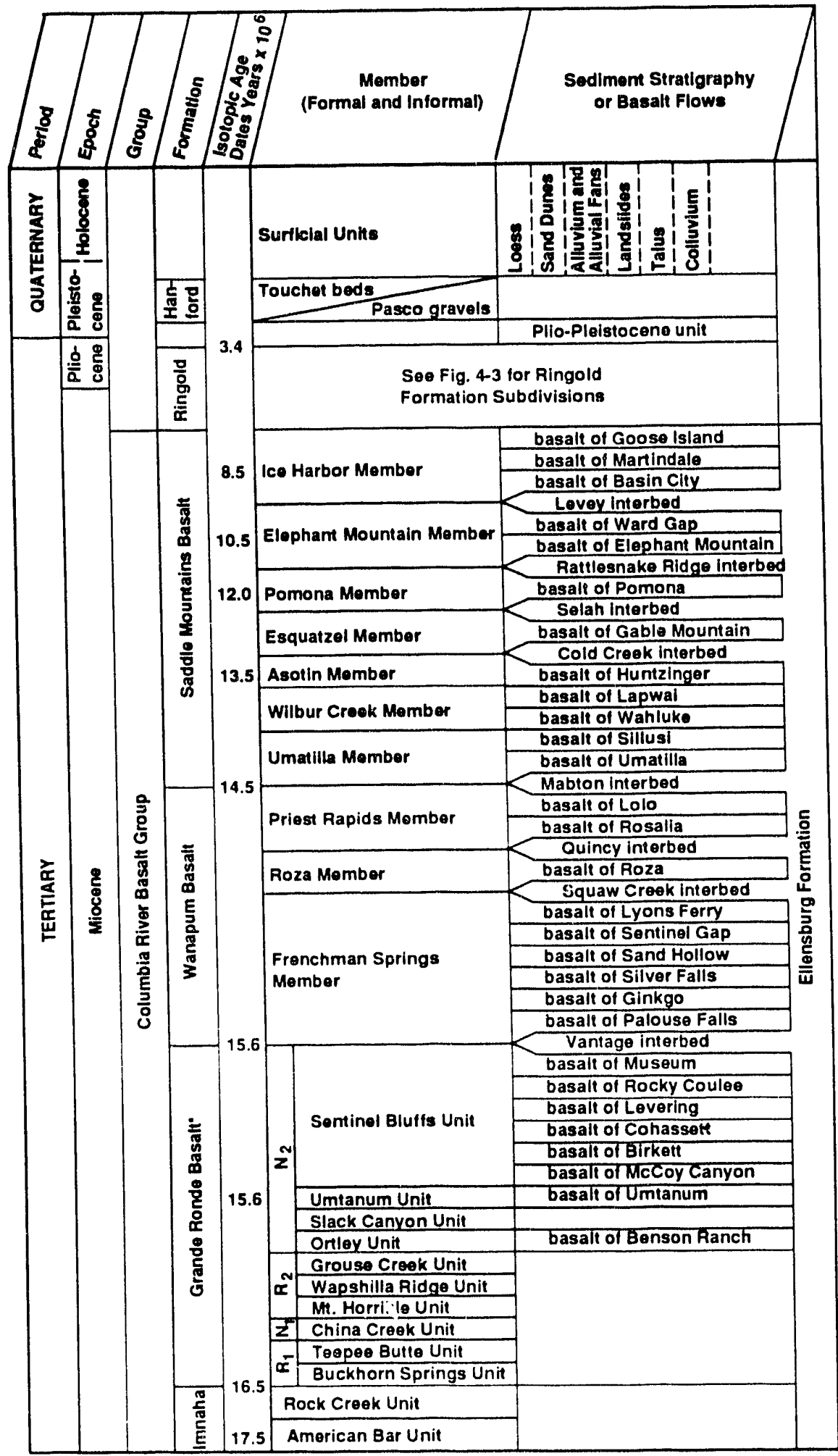

- The Grande Ronde Basalt consists of at least 120 major basalt flows. Only a few flows have been named. $N_{2}, R_{2}, N_{1}$ and $R_{1}$ are magnetostratigraphic units. 
Figure 4-2. Generalized Stratigraphy of the Suprabasalt Sediments in the Pasco Basin.

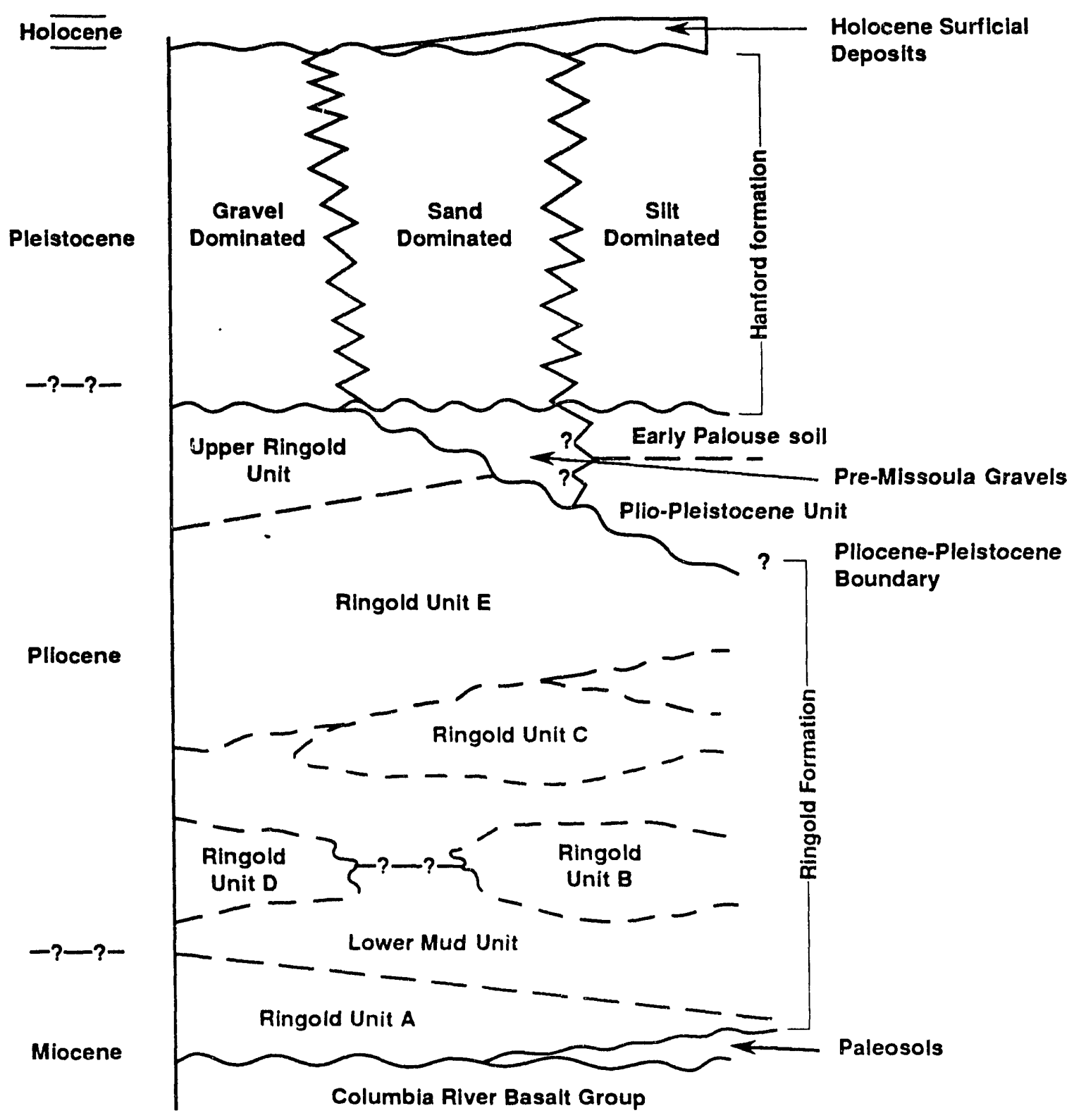

H9210018.1A 
Figure 4-3. Generalized Stratigraphy of the Miocene-Pliocene Ringold Formation in the Pasco Basin. Figure Also Illustrates

the Distribution of Major Sediment Facies

in the Formation (Lindsey 1991).

\section{South of \\ Gable Mountain}

r.
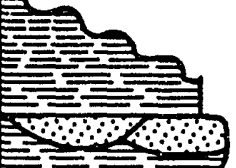

$=0$

$\Rightarrow \equiv$

(1)

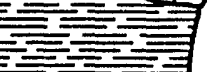

$\because \%=$

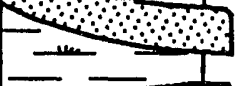

STing

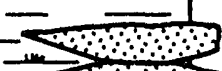

$-19$

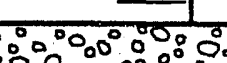

$\therefore 0.00000$

$\because 00000000$

: Gravel Unit E

$\therefore 000 \%$

$\therefore 0.000$

000.00000

10

:0.08.

60000080

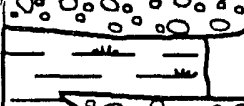

$=0 \% 00$

$\leftarrow$ Gravel Unit D

1000.

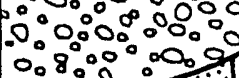

0.800000

Basalt

$\therefore 0 \%$

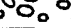

Fluvial Gravel-dominated

Fluvial Sand-dominated
North of Gable Mountain

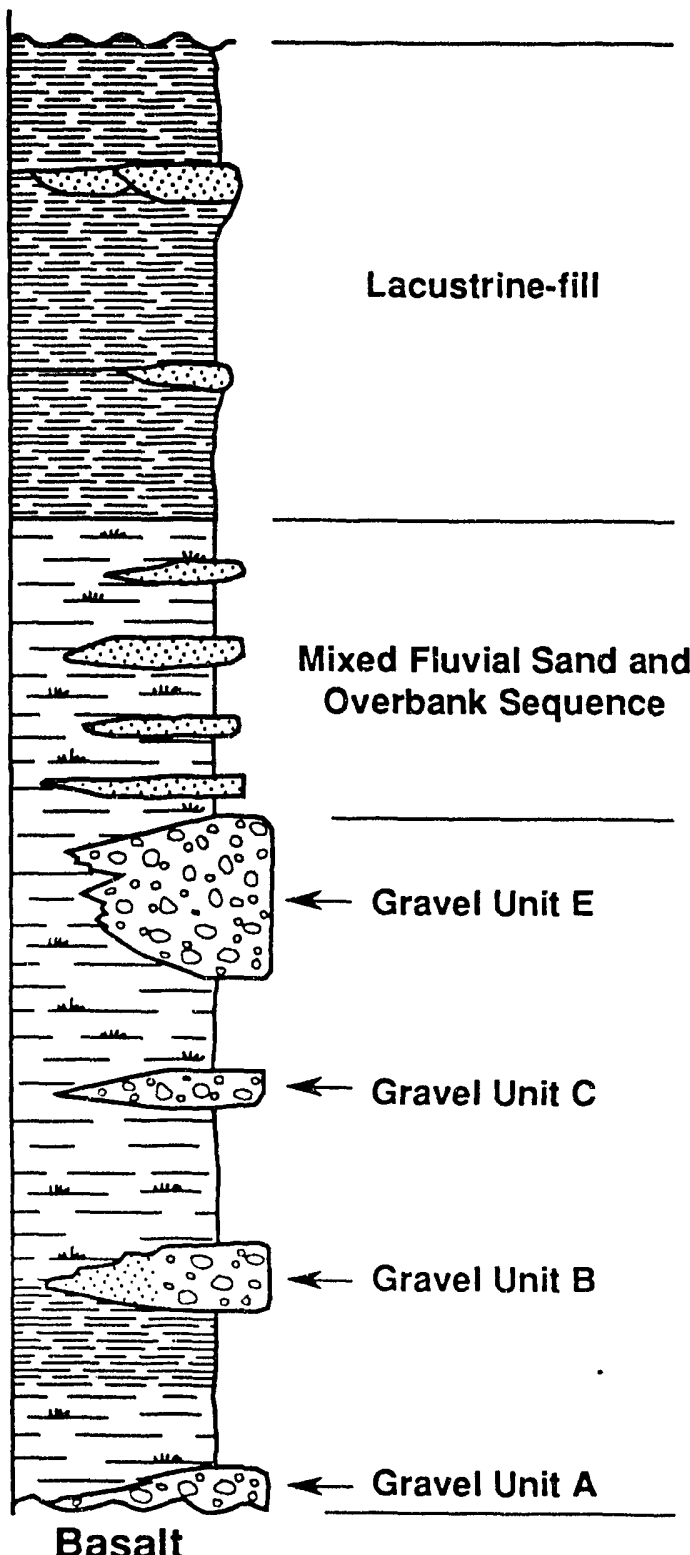

Overbank-dominated "mud" sequence

Lacustrine-dominated 
Figure 4-4. Generalized Hydrologic Setting of the 100-D Area.

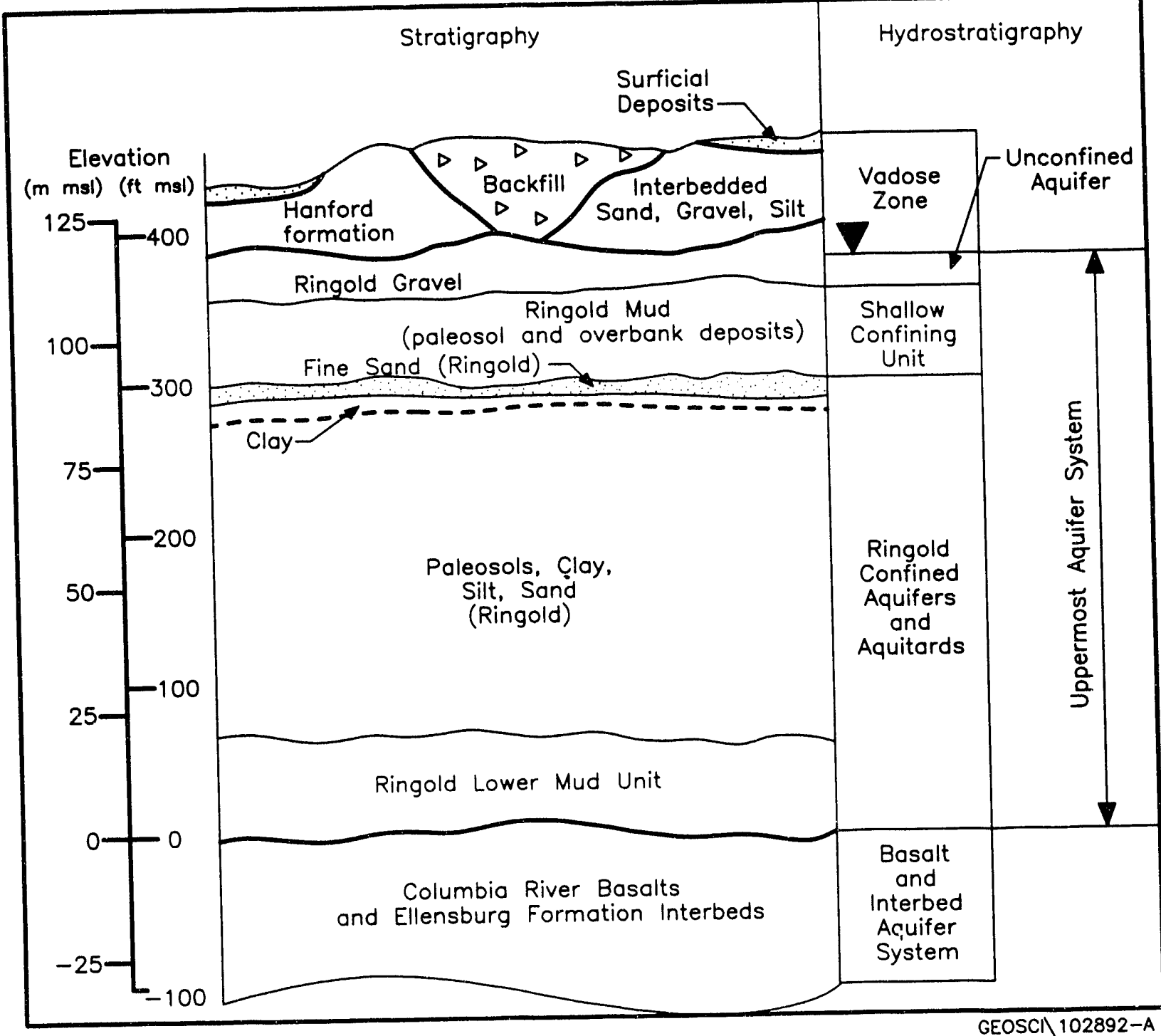

Legend

$\boldsymbol{\nabla}$ Water Table

- Depth of Deepest Borehole
in 100-D Area

Formation Contact

- Facies Contact 
Figure 4-5. Cross-Section of the Vadose Zone and Uppermost Aquifer Beneath the 100-D Ponds.

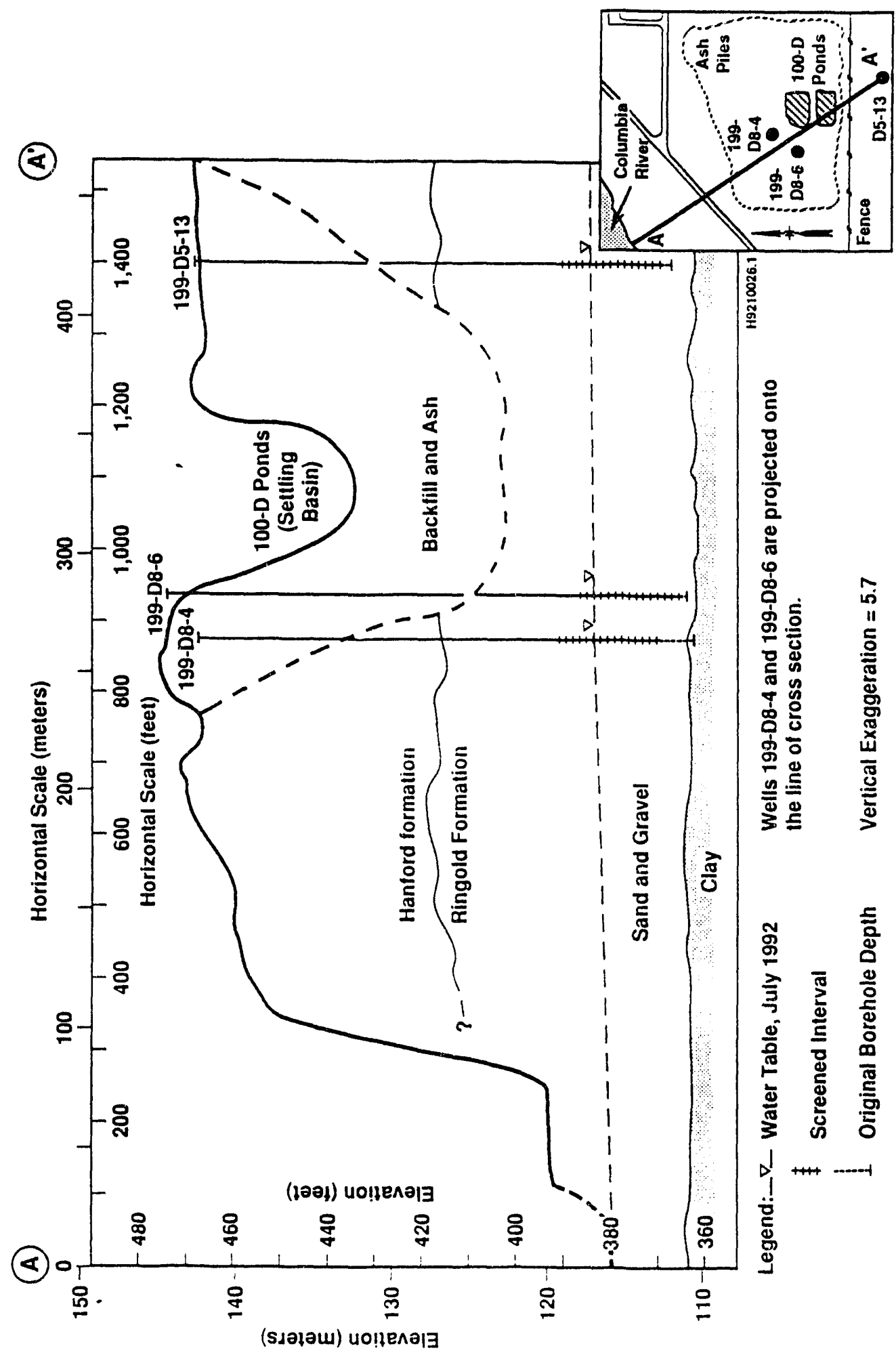


Figure 4-6. Hydrologic Basins Designated for the Washington State Portion of the Columbia Plateau (DOE 1988).

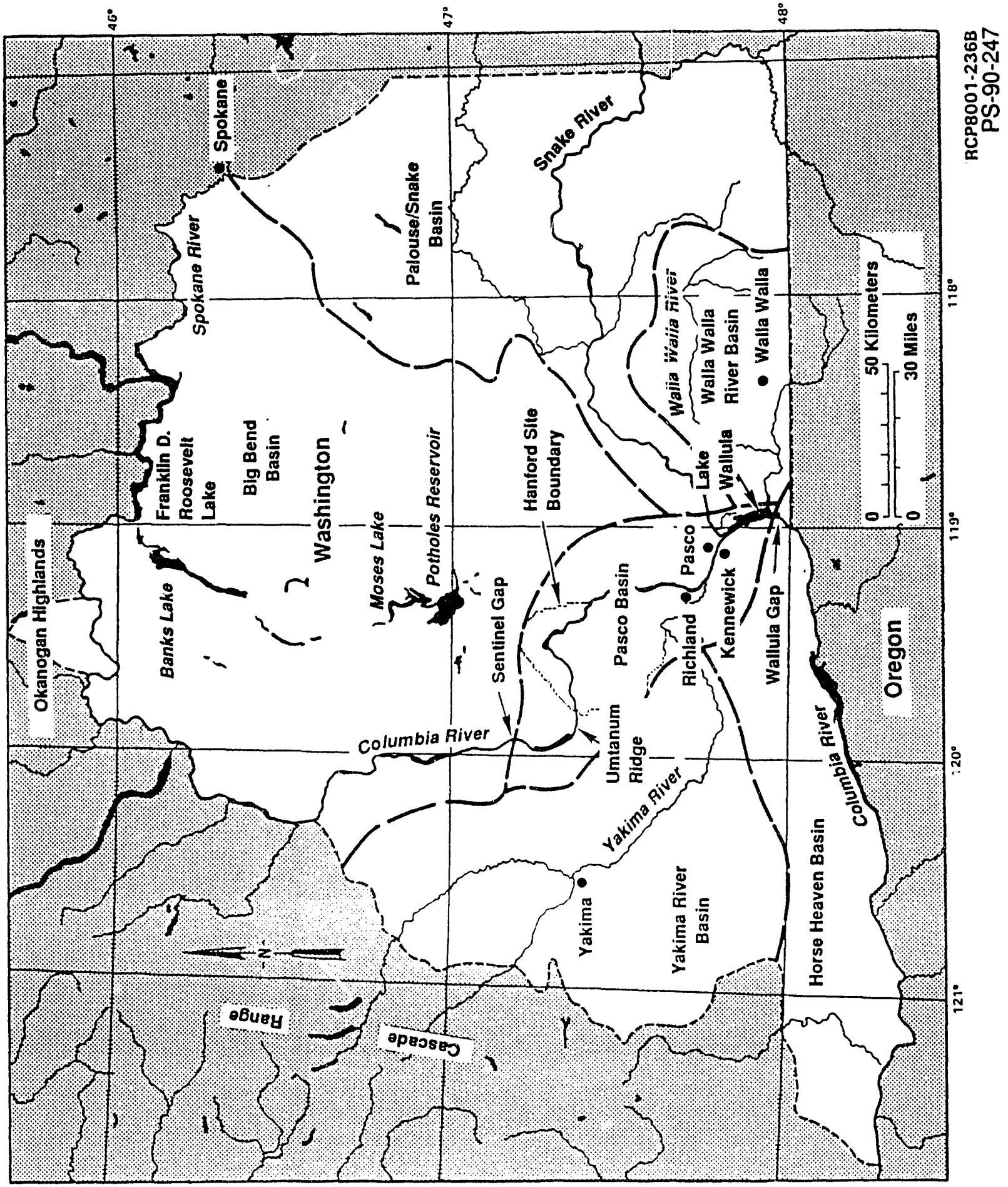


Figure 4-7. Location of Water Disposal Ponds on the Hanford Site.

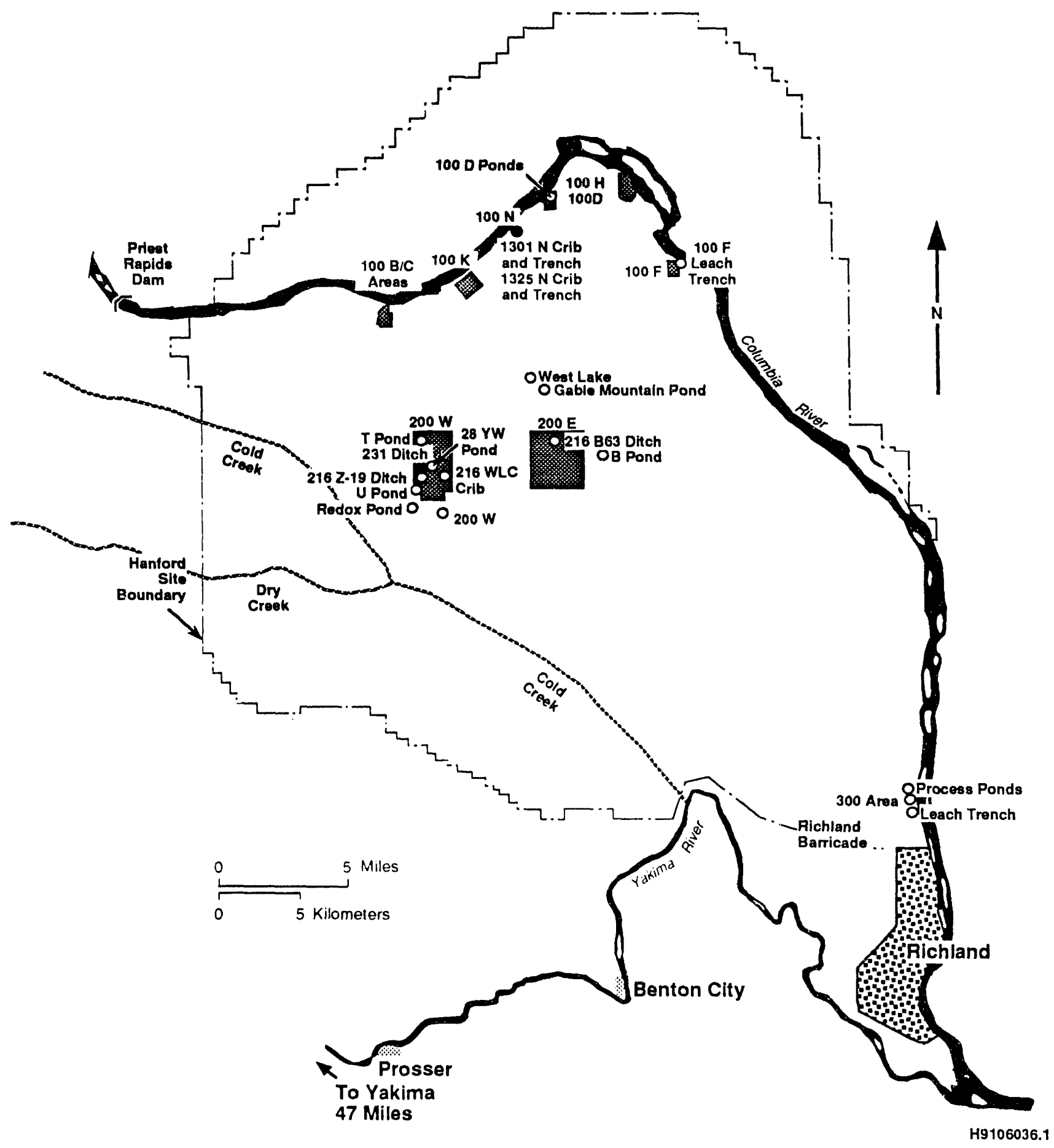


Figure 4-8. Hindcast Water Table Map of the Hanford Site, January 1944 (ERDA 1975).

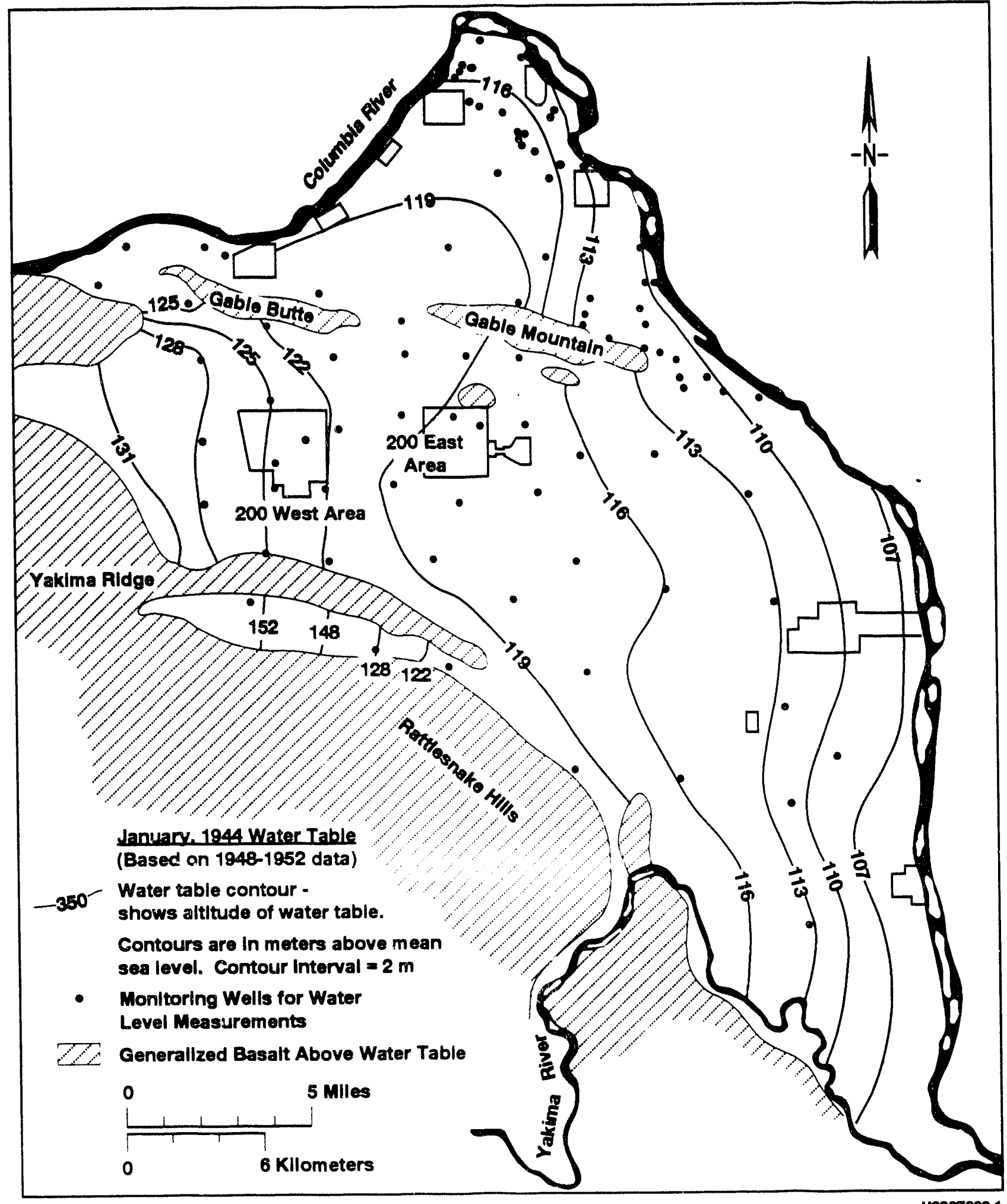


Figure 4-9. Hanford Site Water Table Map, June 1989 (Smith et al. 1990).

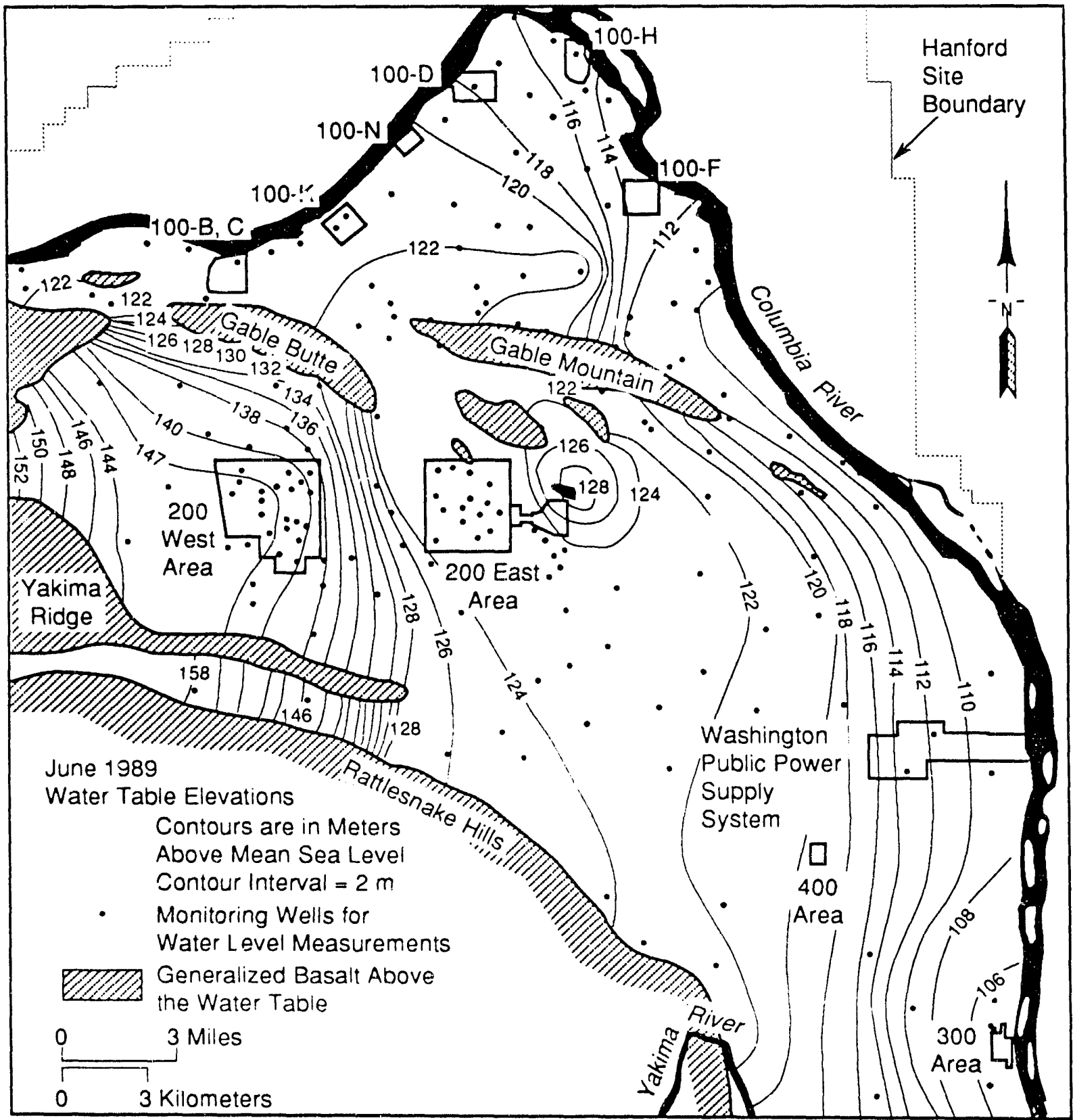

H9102019.5 
Figure 4-10. Water Table in the 100-D Area and Vicinity, June 1992.

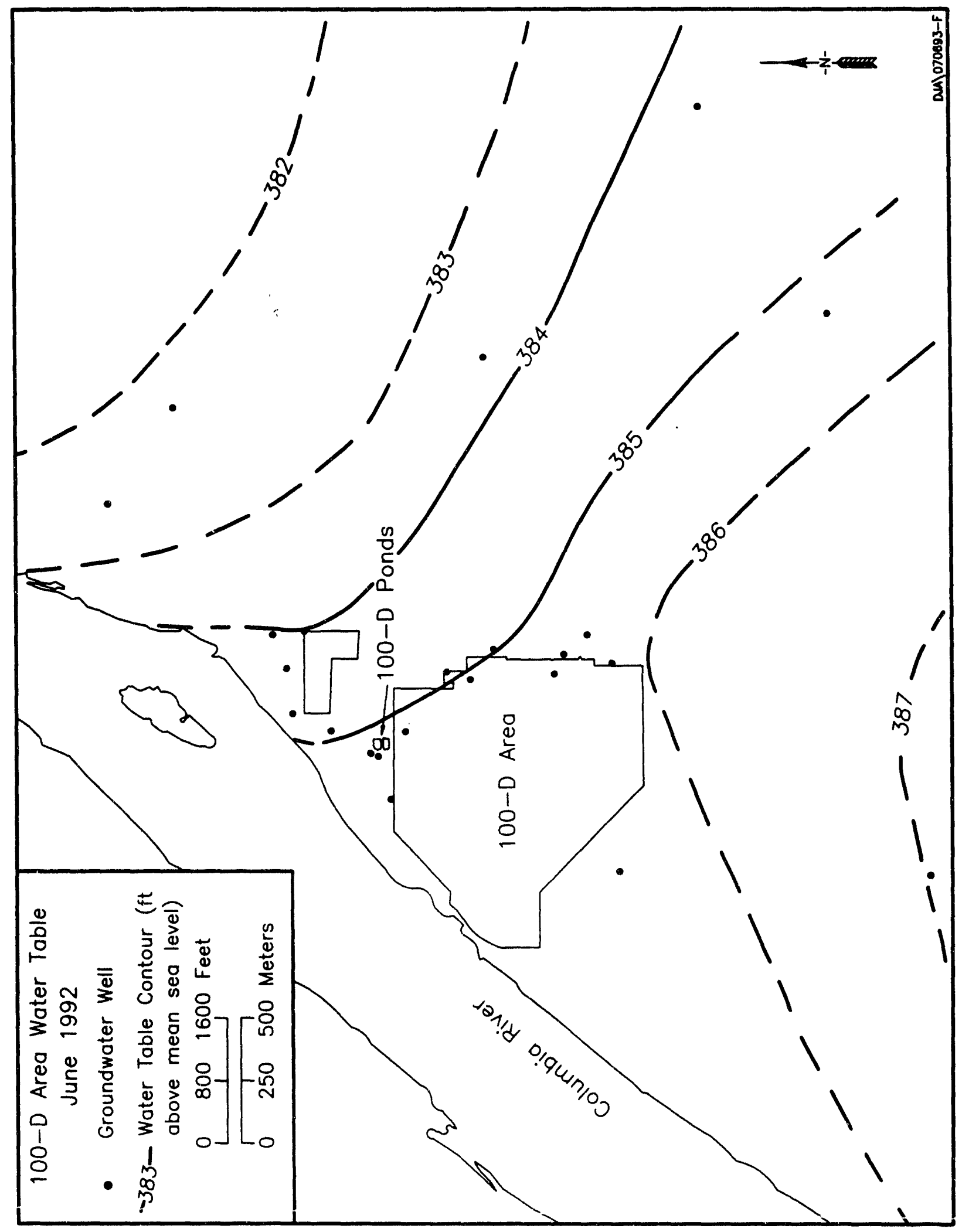


Figure 4-11. Water Table in the 100-D Area and Vicinity, October 1992.

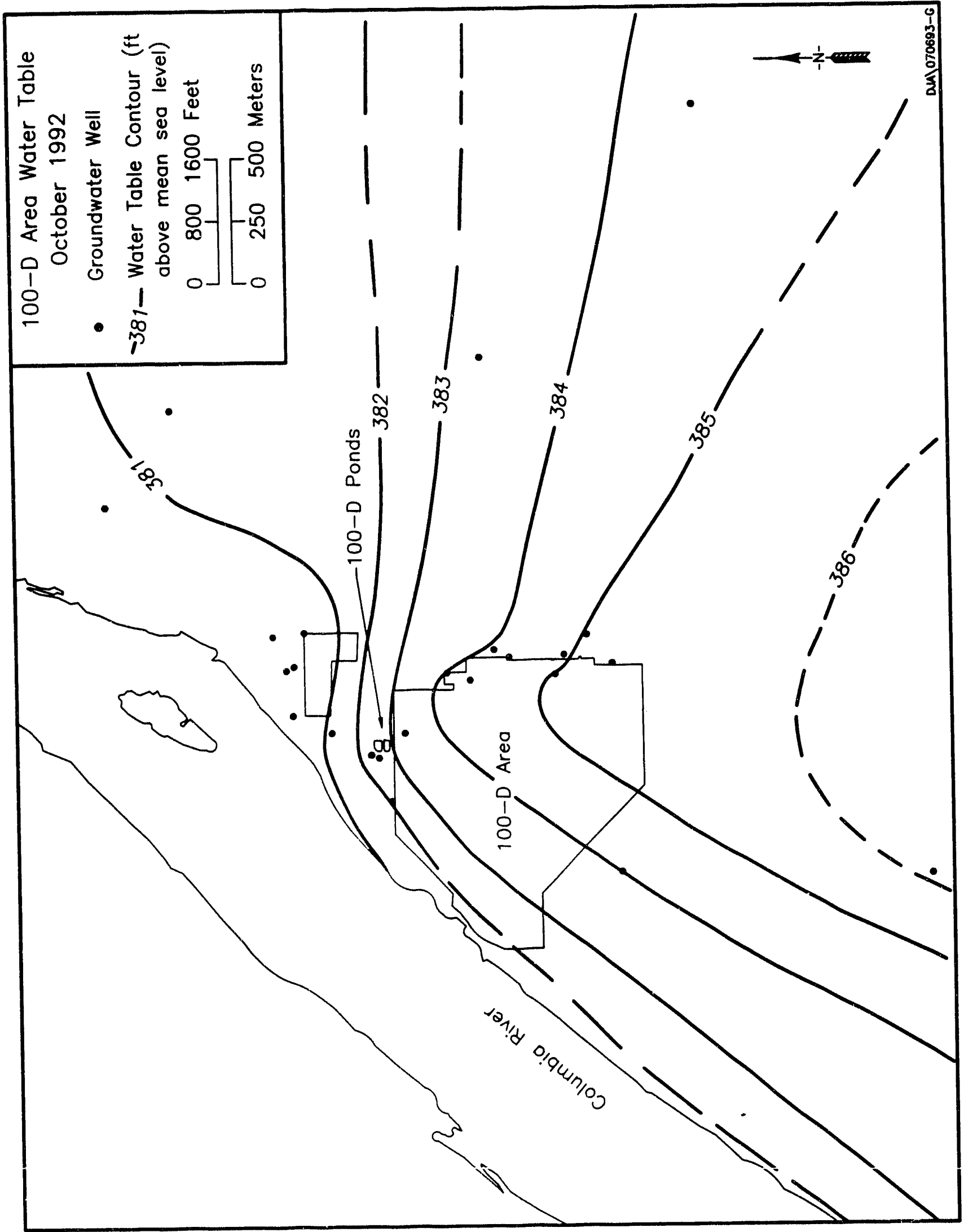


Figure 4-12. Water Table in the 100-D Area and Vicinity, January 1993.

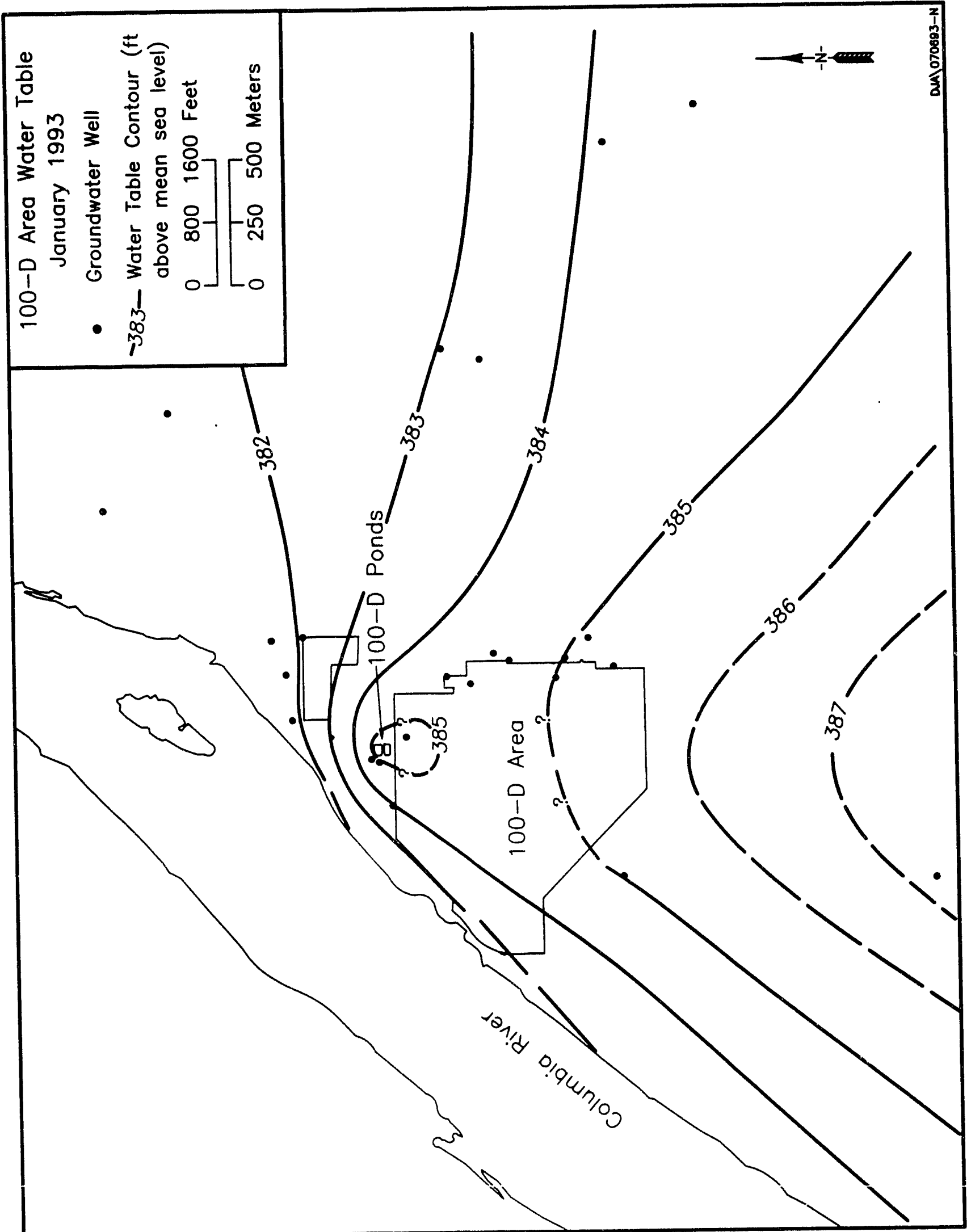


Figure 4-13. Distribution of Tritium in Groundwater in the 100-D Area (Data from May and June 1992).

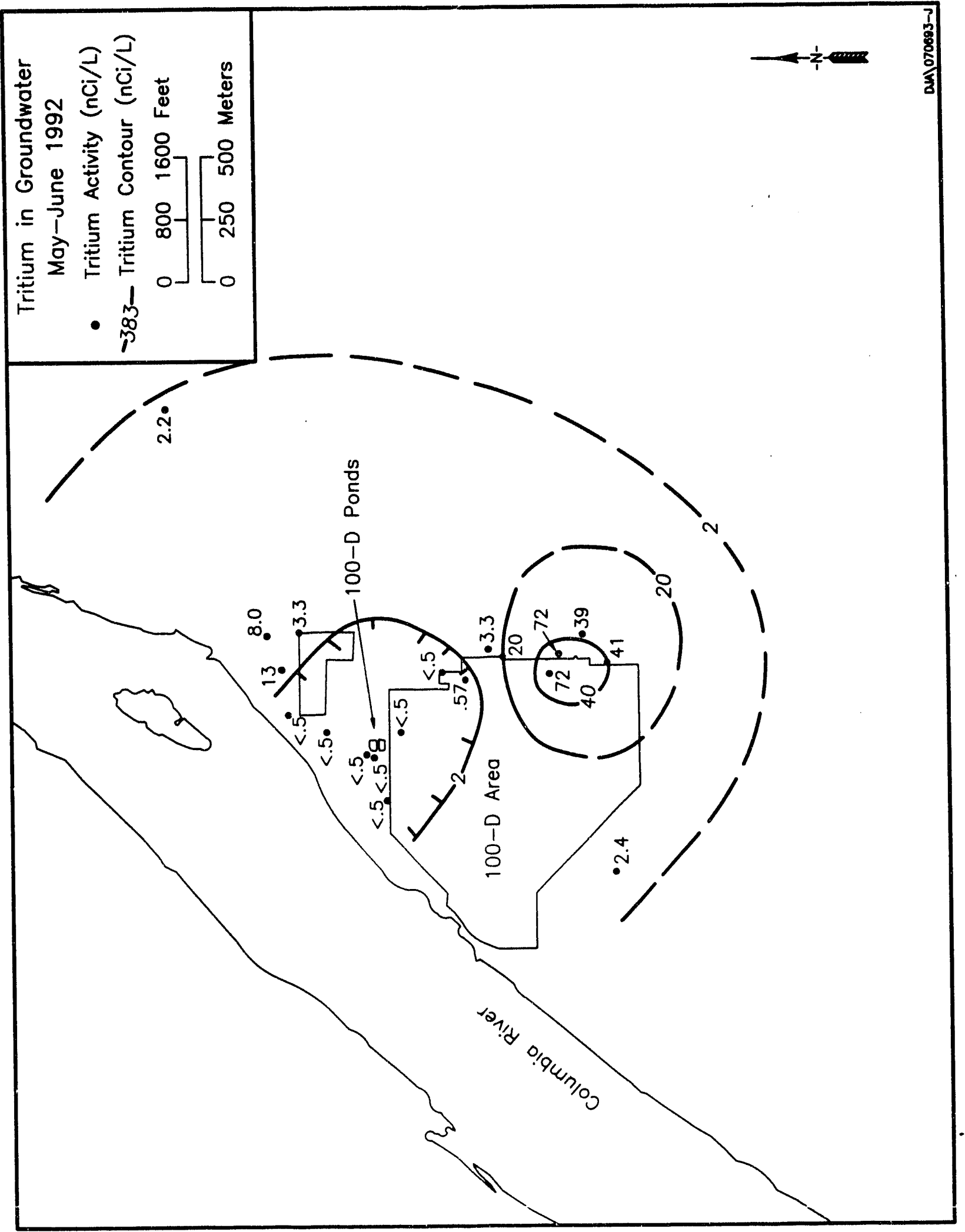


Figure 4-14. Distribution of Chromium in Groundwater in the 100-D Area (Data from May and June 1992).

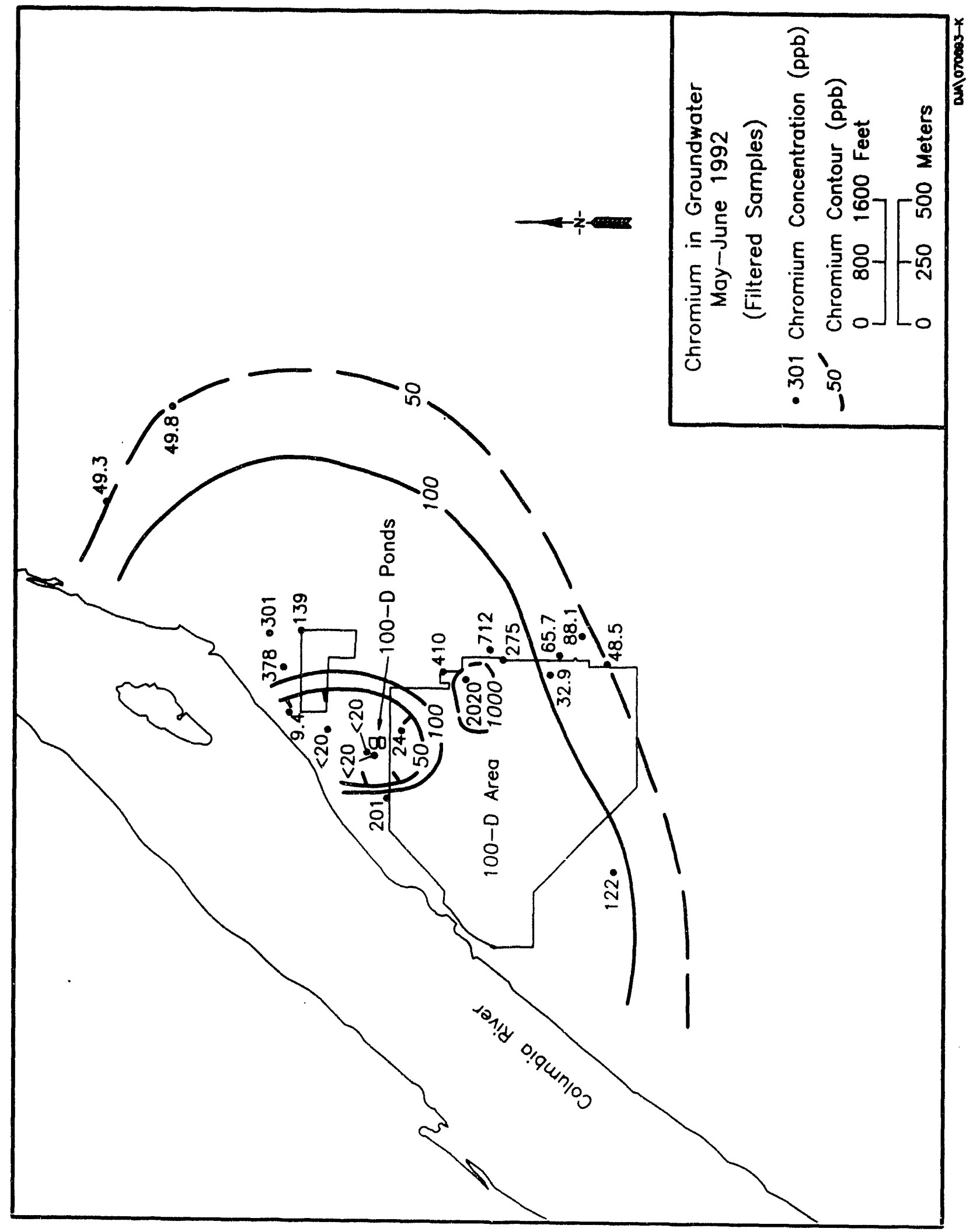


WHC-EP-0666

Figure 4-15. Distribution of Nitrate in Groundwater in the 100-D Area (Data from May and June 1992).

\begin{tabular}{|c|c|c|}
\hline 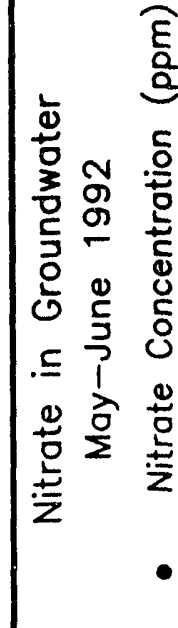 & 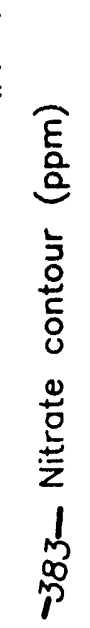 & 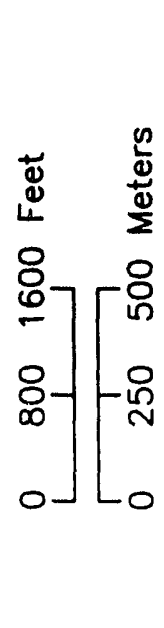 \\
\hline
\end{tabular}

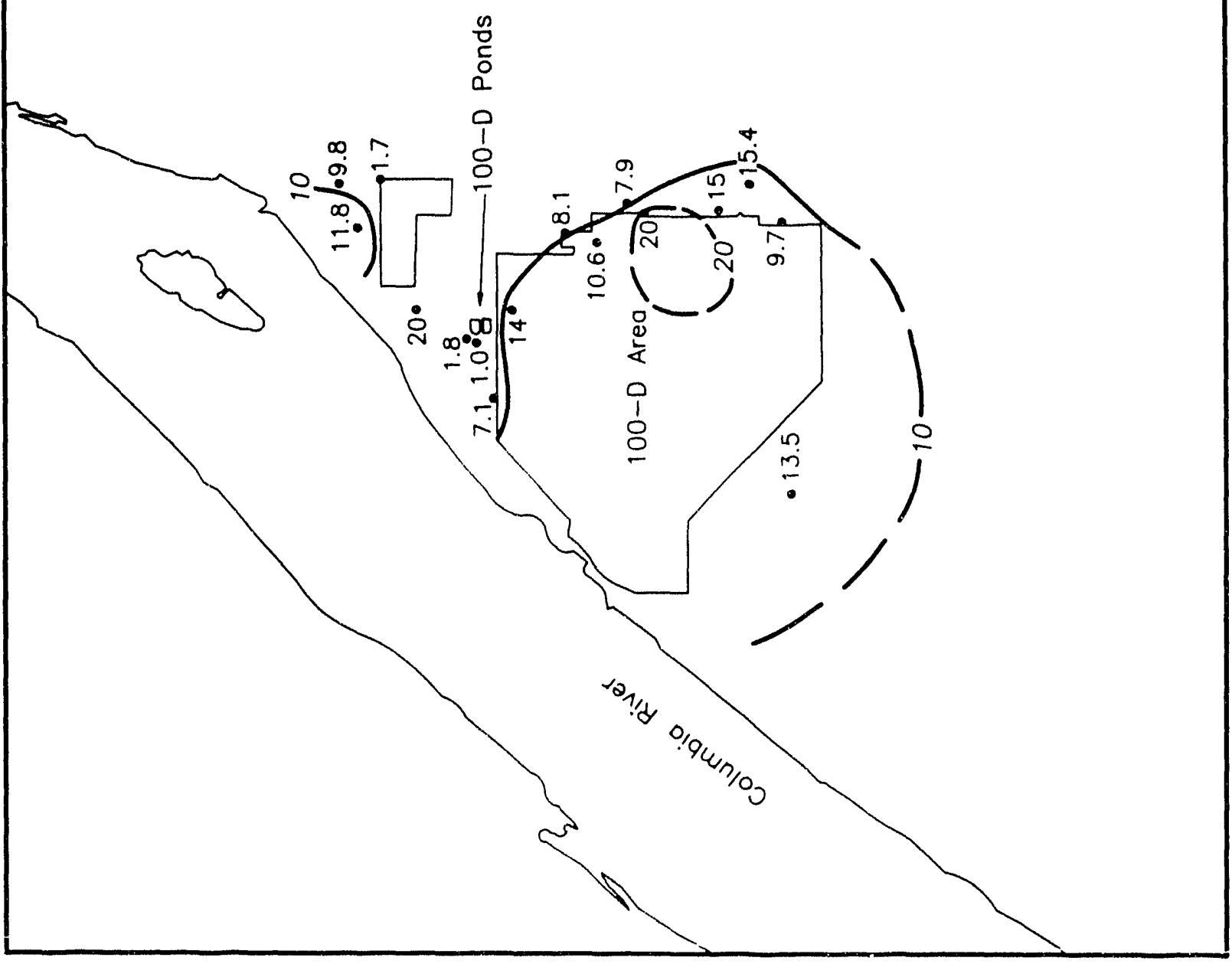


Figure 4-16. (a) pH vs. Time and (b) Specific Conductance in Upgradient Well 199-D5-13 and Downgradient We11s 199-D8-4, -5, and -6 .
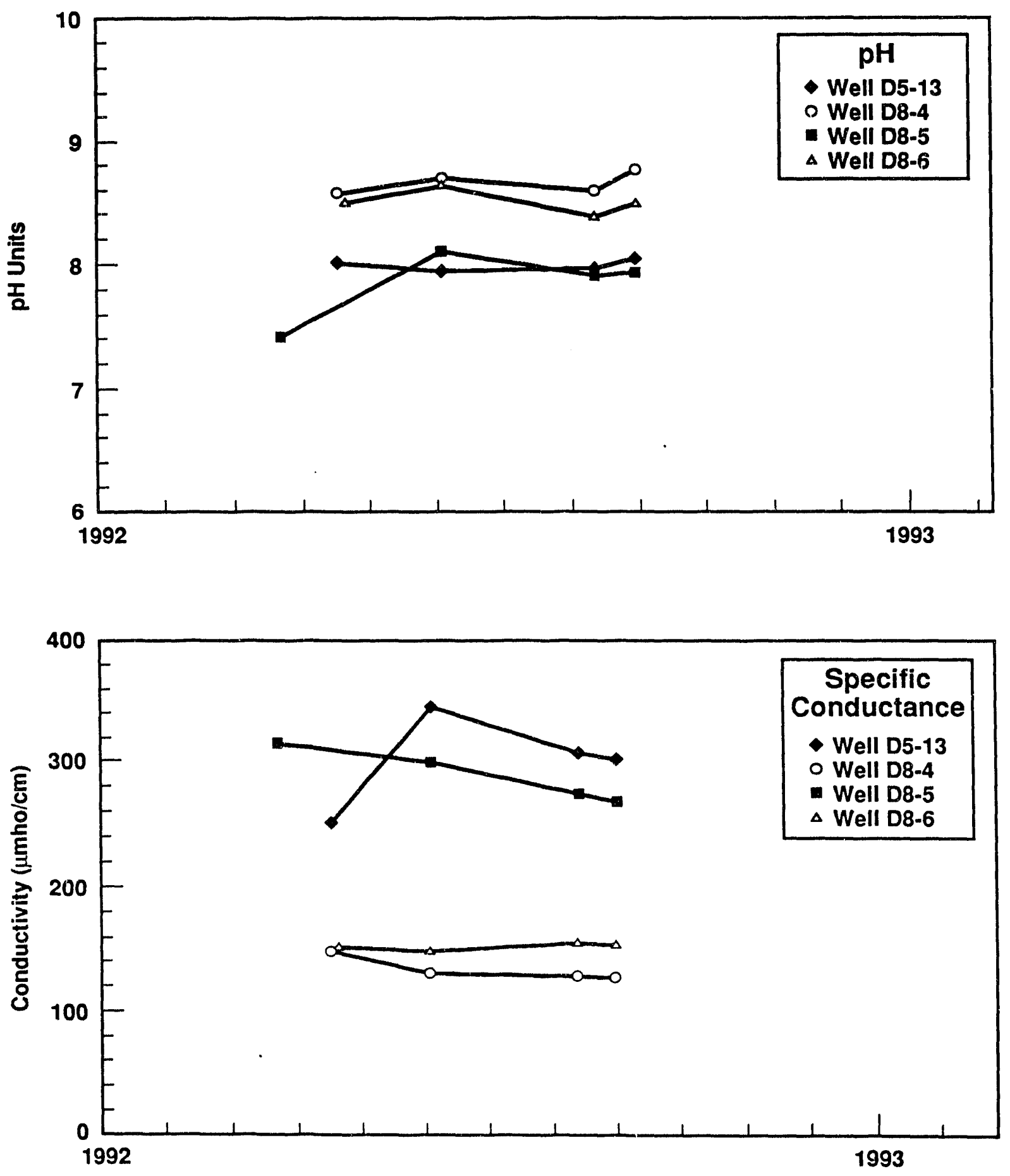

H9307001.2 
Figure 4-17. Distribution of Specific Conductance in Groundwater in the 100-D Area. (Data from May and June 1992).

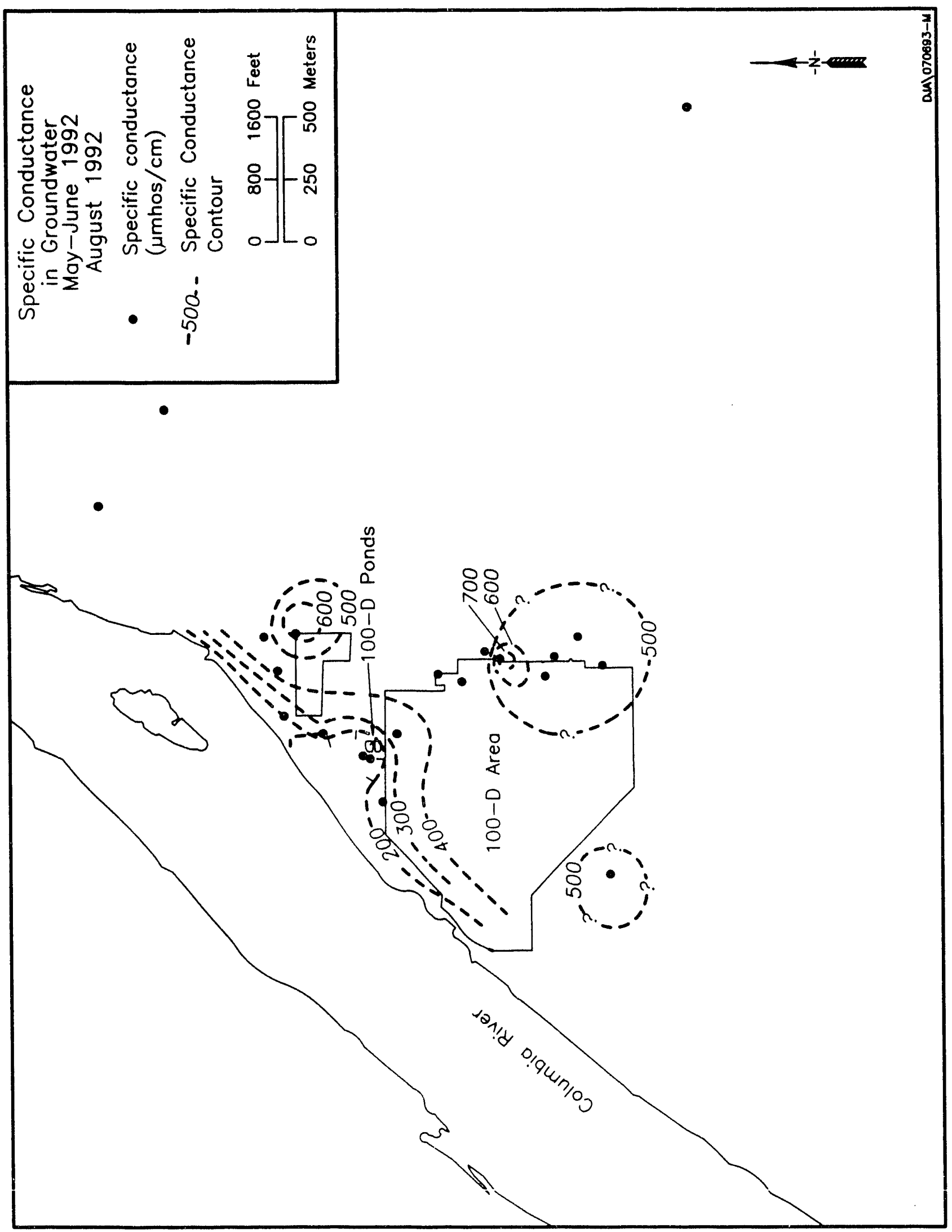


Figure 4-18. 100-D/DR Area - Selected Waste Disposal Facilities and Monitoring Wells.

\section{D/DR Area}

3 Liquid/Sludge Disposal Site

QZ Solid Waste Disposal Site

$\rightarrow$ Existing Well

RCRA Well

CERCLA Well

- Vadose Boring

I 100200 Meters
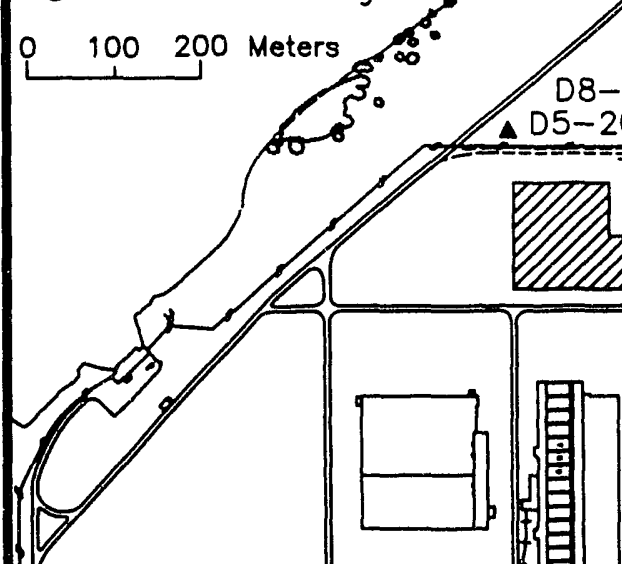

88-6

D8-4

River

$08-55 \triangle 8-548$

$\triangle 08-53$

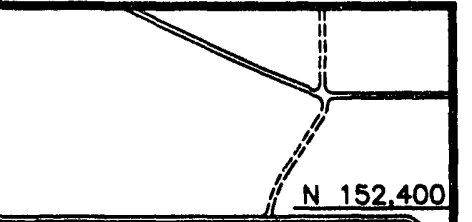

$08-54 A-08-3$

152,400

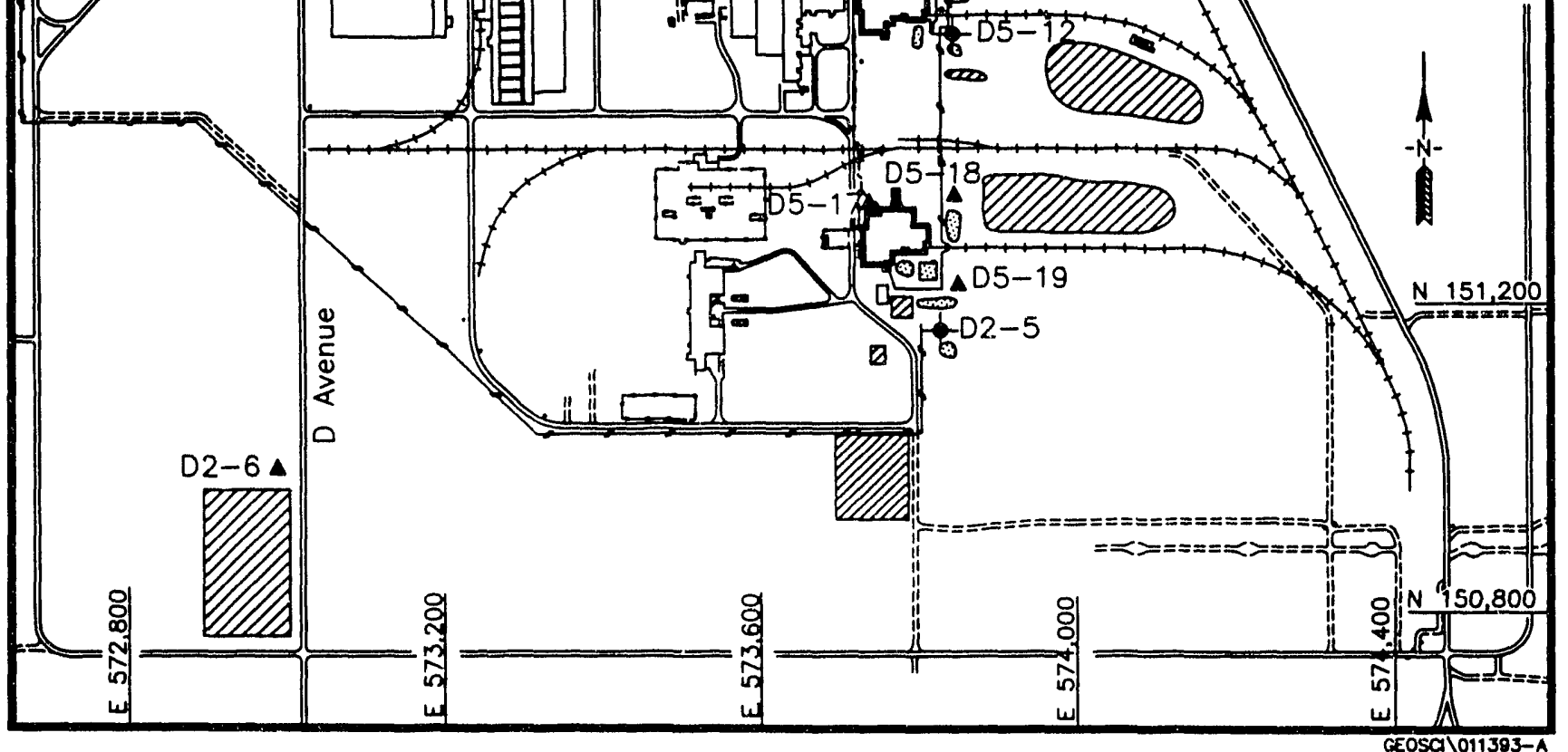


Figure 4-19. Illustrated Conceptual Model for the 100-D Ponds.

(See Figure 4-5 for additional legend explanations)

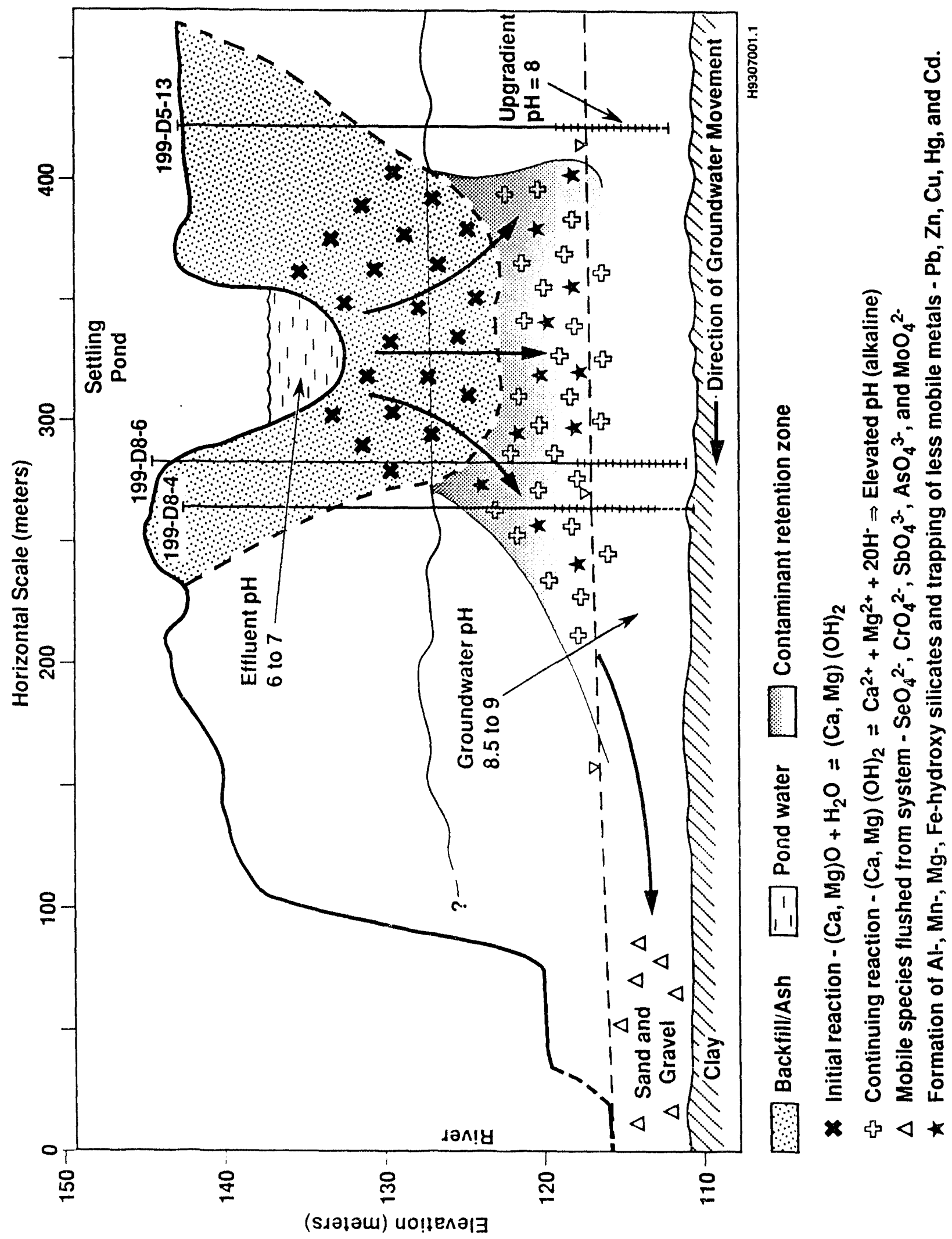


Figure 4-20. Elementary Reactions and Reaction Products for Cadmium in an Alkaline Carbonate System (Rubin 1974).

$$
\begin{aligned}
\mathrm{Cd}^{2+}+\mathrm{HCO}_{3}^{-} & -\mathrm{CdHCO}_{3}^{+} \\
\mathrm{CdHCO}_{3}^{+}+\mathrm{OH}^{-} & -\mathrm{CdCO}_{3(\mathrm{~s})}+\mathrm{H}_{2} \mathrm{O} \\
\mathrm{CdOH}^{+}+\mathrm{HCO}_{3}^{-} & -\mathrm{CdCO}_{3(\mathrm{~s})}+\mathrm{H}_{2} \mathrm{O} \\
\mathrm{Cd}^{2+}+\mathrm{CO}_{3}^{2-} & -\mathrm{CdCO}_{3(\mathrm{~s})} \\
\mathrm{CdCO}_{3(\mathrm{aq})} & -\mathrm{CdCO}_{3(\mathrm{~s})} \\
\mathrm{CdOH}^{+}+\mathrm{OH}^{-} & -{\mathrm{Cd}(\mathrm{OH})_{2(\mathrm{~s})}}_{\mathrm{HCdO}_{2}^{-}+\mathrm{H}_{2} \mathrm{O}}-\mathrm{Cd}(\mathrm{OH})_{2(\mathrm{~s})}+\mathrm{OH}^{-} \\
\mathrm{Cd}(\mathrm{OH})_{2(\mathrm{aq})} & -\mathrm{Cd}(\mathrm{OH})_{2(\mathrm{~s})}
\end{aligned}
$$

In the lower $\mathrm{pH}$ range of 8 to 10 , the predominate reactions for the formation of $\mathrm{CdCO}_{3}$ (cadmium carbonate) are 1 through 5. In the higher $\mathrm{pH}$ range of 10 to 12, reactions 6 through 8 are the dominate ones. In this perspective, $\mathrm{Cd}^{2+}$ and $\mathrm{CdOH}^{+}$are the only reasonable species that could form $\mathrm{CdCO}_{3}$ and they do not exist at $\mathrm{pH}$ values above 12. It is possible for cadmium hydroxide to form and exist in the lower $\mathrm{pH}$ ranges, but formation of the carbonate species is favored (Rubin 1974). 
Table 4-1. Hydraulic Parameters for Various Areas at the Hanford Site

\begin{tabular}{|c|c|c|c|c|c|c|c|c|c|c|c|c|}
\hline 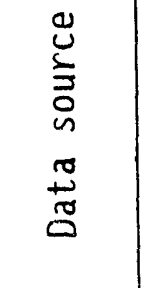 & 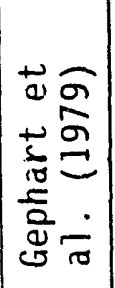 & 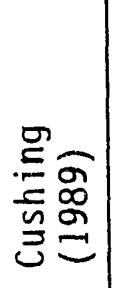 & 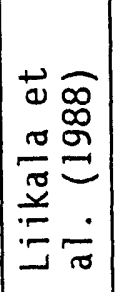 & 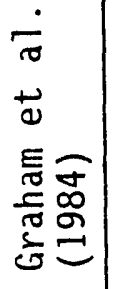 & 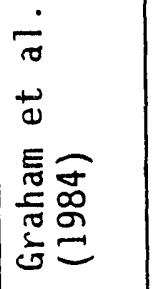 & 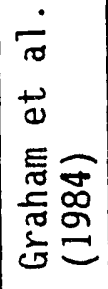 & 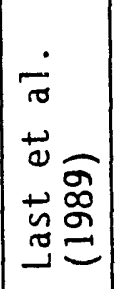 & 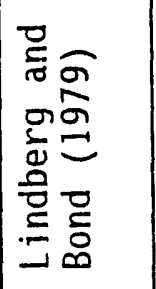 & 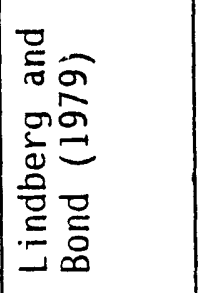 & 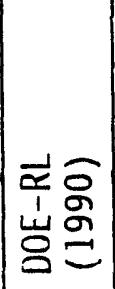 & 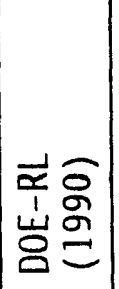 & 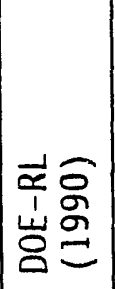 \\
\hline 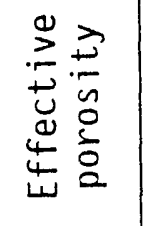 & ठ으 & ̊ํํ & 1 & 1 & 1 & 1 & l & $i$ & $i$ & i & I & 1 \\
\hline 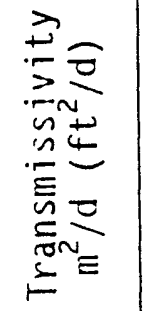 & $i$ & $i$ & $\mid \begin{array}{cc}1 & 0 \\
0 & 0 \\
ㅅ & 0 \\
1 & 0\end{array}$ & $\begin{array}{l}0 \\
0 \\
-1 \\
-1 \\
1 \\
\infty\end{array}$ & 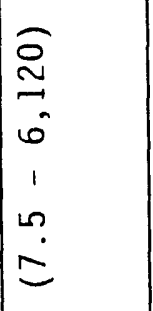 & $\begin{array}{l}n \\
0 \\
0 \\
x \\
m\end{array}$ & 1 & i & i & 1 & $\begin{array}{l}1 \\
1\end{array}$ & 1 \\
\hline 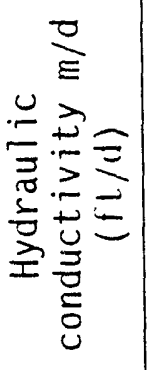 & $\begin{array}{l}0 \\
8 \\
1 \\
0\end{array}$ & $\begin{array}{l}0 \\
0 \\
0 \\
1 \\
10 \\
\cong \\
\cong\end{array}$ & 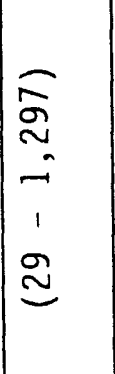 & 1 & 1 & 1 & $\begin{array}{l}0 \\
0 \\
0 \\
1 \\
0 \\
0\end{array}$ & $\begin{array}{c}\widehat{c} \\
1 \\
\overline{1} \\
0 \\
0 \\
x \\
m\end{array}$ & 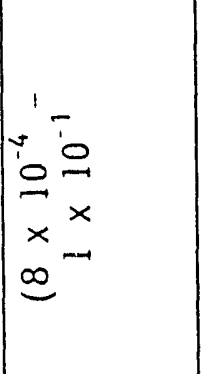 & 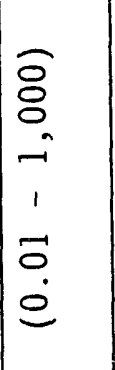 & $\begin{array}{l}0 \\
8 \\
0 \\
0 \\
1 \\
\sigma \\
\vdots \\
=\end{array}$ & $\begin{array}{l}0 \\
8 \\
0 \\
0 \\
10 \\
1 \\
8 \\
0 \\
0 \\
\equiv\end{array}$ \\
\hline 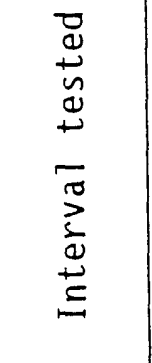 & 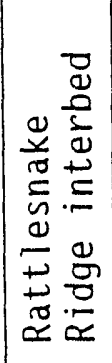 & 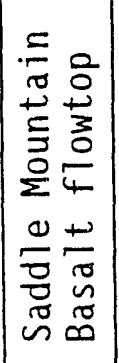 & 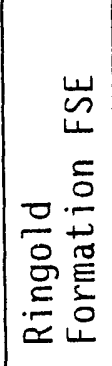 & 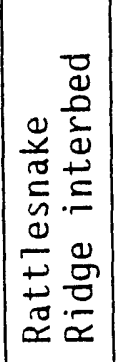 & 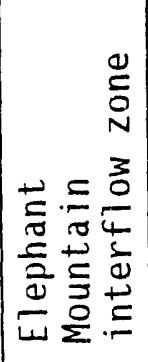 & 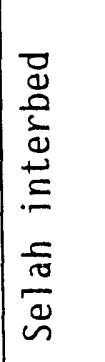 & 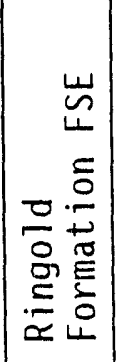 & 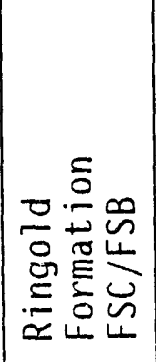 & 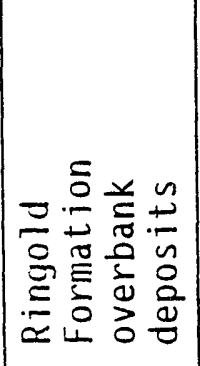 & 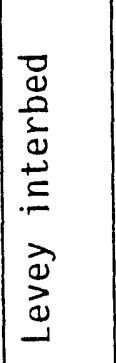 & 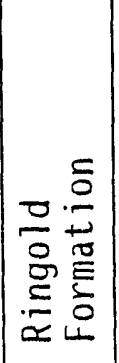 & 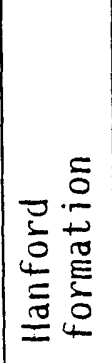 \\
\hline 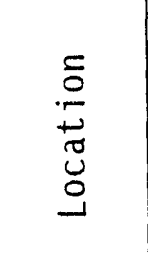 & $\begin{array}{l}0 \\
0 \\
0 \\
\alpha \\
0 \\
0 \\
0\end{array}$ & $\begin{array}{l}0 \\
\pm \\
i n \\
0 \\
0 \\
0 \\
4 \\
\frac{1}{5} \\
\frac{\pi}{1}\end{array}$ & $\begin{array}{l}\underset{0}{0} \\
\frac{1}{2} \\
0 \\
0\end{array}$ & $\begin{array}{l}0 \\
d \\
\frac{1}{2} \\
0 \\
0 \\
\sim\end{array}$ & 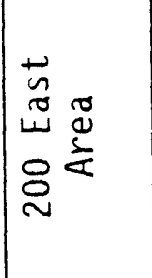 & $\begin{array}{l}\stackrel{0}{ \pm} \\
\text { in } \\
0 \\
0 \\
0 \\
4 \\
\frac{1}{5} \\
\frac{1}{1}\end{array}$ & 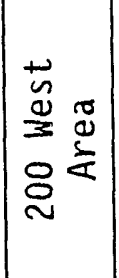 & $\mid \begin{array}{l}0 \\
0 \\
\frac{1}{2} \\
0 \\
0 \\
0 \\
=\end{array}$ & 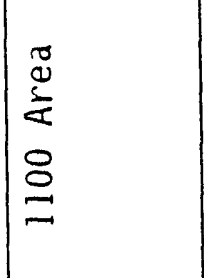 & 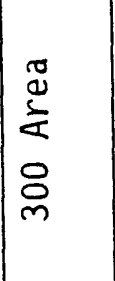 & $\mid \begin{array}{l}0 \\
0 \\
\frac{1}{\alpha} \\
0 \\
0 \\
m\end{array}$ & 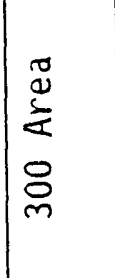 \\
\hline
\end{tabular}


Table 4-2. Hanford Site Maxima and Average Concentrations (ppm) for Unconfined Aquifers, Springs, and Confined Aquifers (DOE-RL 1992d).

\begin{tabular}{|c|c|c|c|c|c|c|}
\hline Chem. & $\begin{array}{l}\text { Unconf ined } \\
\text { average }\end{array}$ & $\begin{array}{l}\text { Springs } \\
\text { average } \\
\end{array}$ & $\begin{array}{c}\text { Conf ined } \\
\text { average }\end{array}$ & $\begin{array}{c}\text { Uncont ined } \\
\text { maxima }\end{array}$ & $\begin{array}{c}\text { Springs } \\
\text { maxima }\end{array}$ & $\begin{array}{l}\text { Confined } \\
\text { maxima }\end{array}$ \\
\hline Al & 0.145 & 0.15 & 0.069 & 0.202 & 0.2 & 0.14 \\
\hline B & 0.072 & 0.08 & 0.009 & 0.101 & 0.1 & 0.02 \\
\hline $\mathrm{Ba}$ & 0.036 & 0.01 & 0.078 & 0.062 & 0.025 & 0.129 \\
\hline $\mathrm{Ca}$ & 35 & 23 & 29.9 & 56 & 34 & 92 \\
\hline $\mathrm{Cl}$ & 3.9 & 6.1 & 12.3 & 6.3 & 16.9 & 28 \\
\hline $\mathrm{Co}$ & 0.02 & 0.016 & 0.026 & 0.12 & 34 & 0.16 \\
\hline $\mathrm{Cr}$ & 0.032 & 0.033 & 0.006 & 0.033 & 0.036 & 0.012 \\
\hline $\mathrm{Cu}$ & 0.023 & 0.021 & 0.003 & 0.03 & 0.03 & 0.01 \\
\hline$F$ & 0.39 & 0.35 & 0.73 & 0.61 & 0.7 & 3.3 \\
\hline $\mathrm{F}-\mathrm{a} / \mathrm{k}$ & 136 & 94 & 120 & 215 & 134 & 158 \\
\hline $\mathrm{Fe}$ & 0.215 & 0.024 & 0.097 & 0.695 & 0.034 & 0.61 \\
\hline$K$ & 4.1 & 2.2 & 8.1 & 5.5 & 6.2 & 13.1 \\
\hline $\mathrm{Li}$ & 0.013 & 0.013 & 0.02 & 0.016 & 0.016 & 0.02 \\
\hline $\mathrm{Mg}$ & 11.3 & 10.3 & 8.9 & 16.5 & 15.4 & 15.9 \\
\hline$M n$ & 0.06 & 0.008 & 0.18 & 0.164 & 0.01 & 0.5 \\
\hline Mo & 0.41 & -- & 0.11 & 0.61 & 0.61 & 0.2 \\
\hline $\mathrm{Na}$ & 12 & 9.6 & 26.2 & 17 & 22.9 & 5.8 \\
\hline $\mathrm{Ni}$ & 0.03 & 0.03 & 0.012 & 0.036 & 0.03 & 0.02 \\
\hline $\mathrm{NO}_{3}$ & 3.4 & 6.5 & 3 & 7.1 & 39.8 & 8 \\
\hline $\mathrm{Pb}$ & 0.18 & 0.17 & 0.043 & 0.2 & 0.18 & 0.1 \\
\hline $\mathrm{Si}$ & 19 & 21 & 30 & 27 & 28 & 37 \\
\hline $\mathrm{SO}_{4}$ & 17 & 13 & 24 & 24 & 24 & 40 \\
\hline$S r$ & 0.15 & 0.08 & 0.09 & 0.25 & 0.12 & 0.16 \\
\hline $\mathrm{Zn}$ & 0.018 & 0.97 & 0.1 & 0.62 & 7.2 & 0.226 \\
\hline
\end{tabular}


Introduction to Tables 4-3 Through 4-7.

All tables contain data taken from the Hanford Environmental Information Syste (HEIS) database. The following criteria apply to these data:

1. Data include RCRA, CERCLA, operational, and historical sampling data that have been entered into the database up to May 1993.

2. All data are from samples collected in the 1990's except chloride data where 1980 's data were also used to make a more complete data set.

3. The data given for a year are the average of all the data available for that year and are rounded to the nearest tenth or hundredth of a decimal (e.g., $0.15 \Rightarrow 0.2$ or $0.031 \Rightarrow 0.03)$.

4. All data are for unfiltered samples.

5. Units for each parameter are given in the header of the table.

6. Radionuclide data include some negative values, which result when samplas are at or near the detection 1 imit and/or background values are subtracted fro the results.

7. A "U" flag after a data entry means "undetected" and value is less than the contractua?ly required quantification limit (CQRL). 
Table 4-3. Groundwater Quality Indicator Monitoring Results. (sheet 1 of 2)

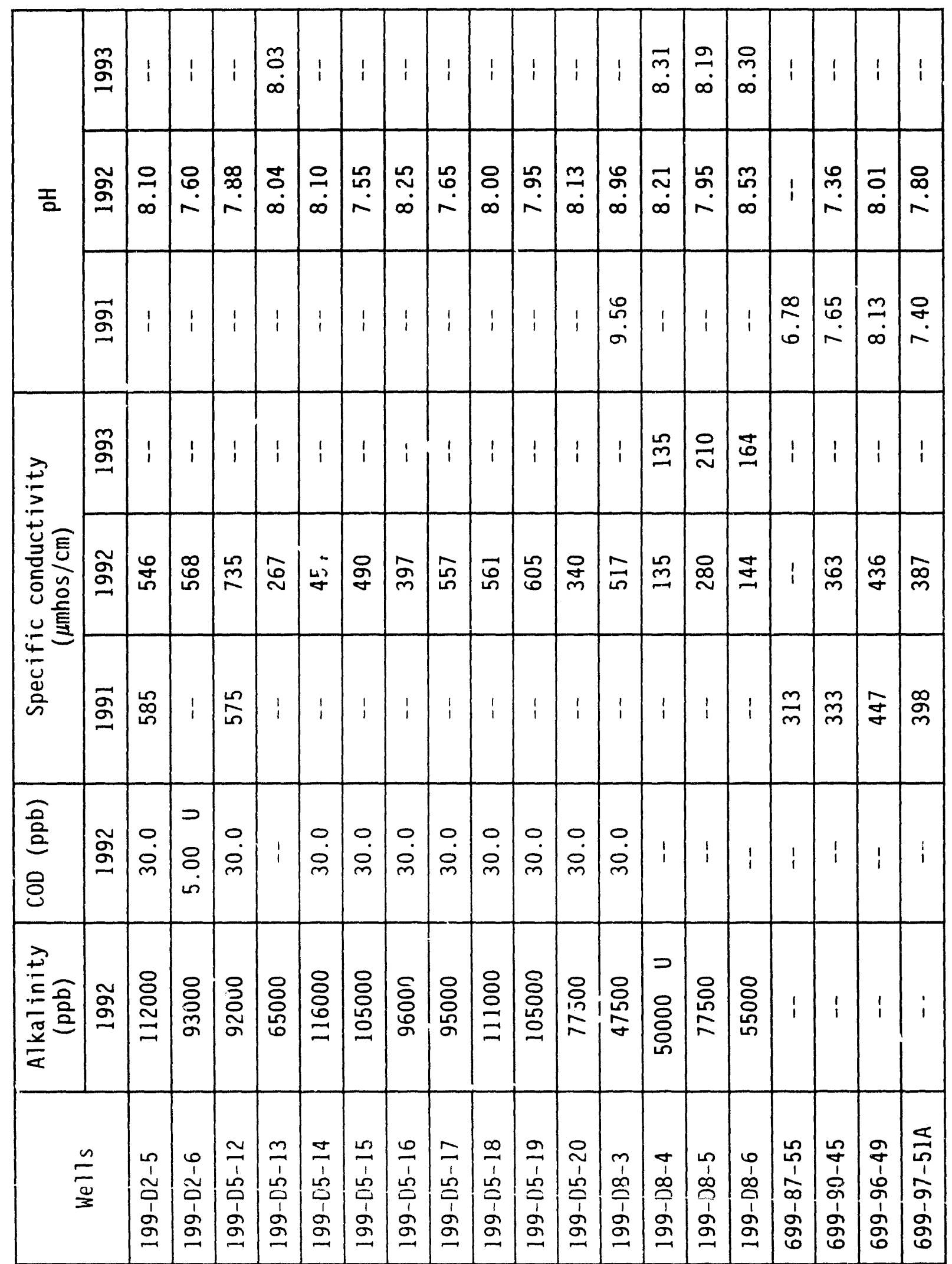


Table 4-3. Groundwater Quality Indicator Monitoring Results. (sheet 2 of 2)

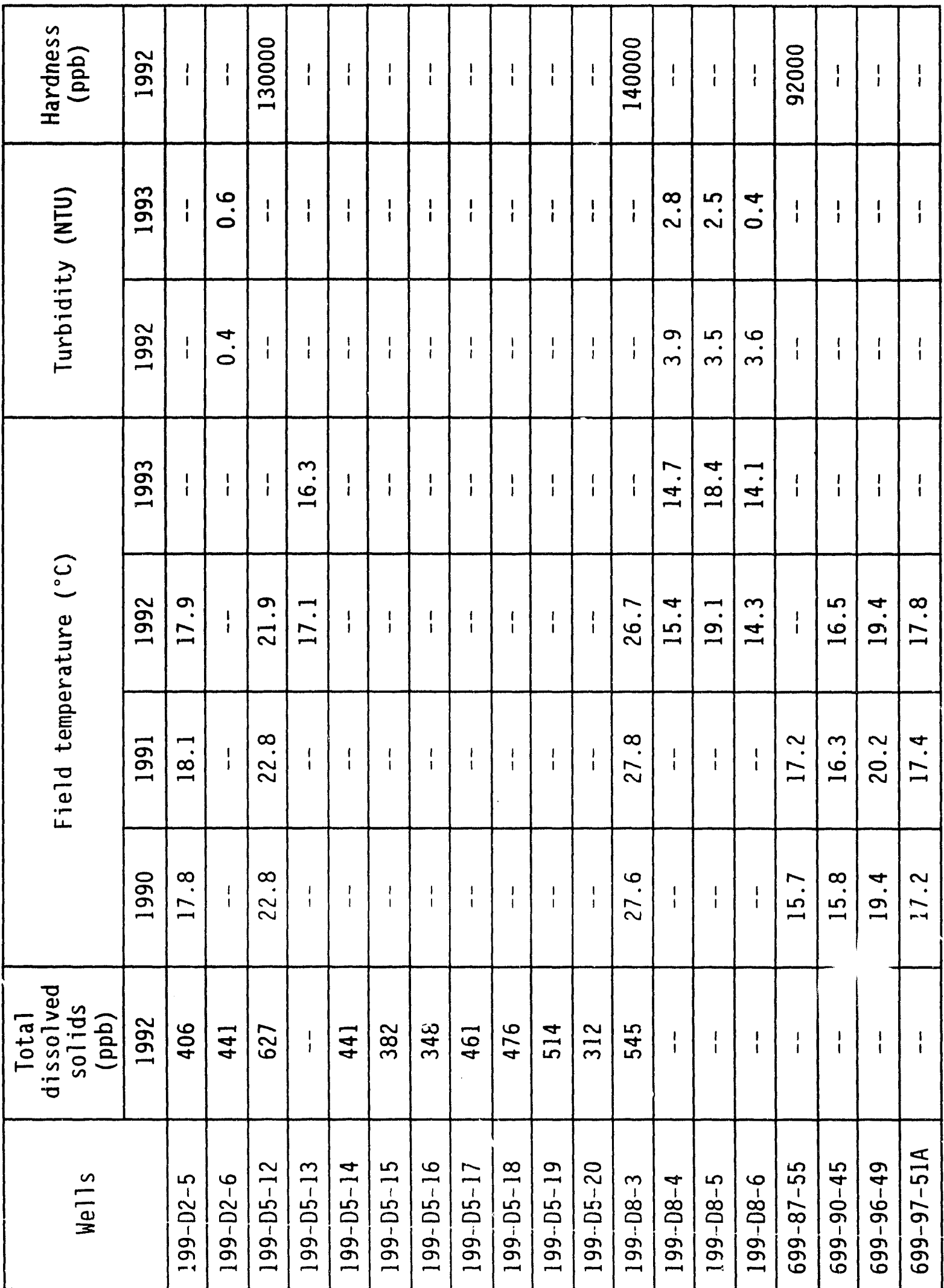


Table 4-4. Cation Monitoring Results.

\begin{tabular}{|c|c|c|c|c|c|c|c|c|c|c|c|c|c|c|c|c|c|c|c|c|}
\hline \multirow{4}{*}{ 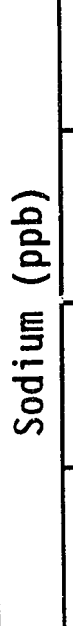 } & \%̆ & 1 & 1 & 1 & 응 & 1 & i & i & $i$ & i & 1 & $i$ & i & $\frac{8}{8}$ & 음 & 怘 & i & 1 & 1 & i \\
\hline & જั & 옳 & 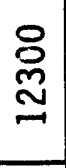 & 足 & $\begin{array}{l}\text { 윰 } \\
\text { g }\end{array}$ & 오․ & $\begin{array}{l}8 \\
8 \\
\text { 음 }\end{array}$ & 옳 & 옹 & 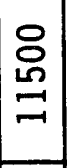 & 욤 & $\begin{array}{l}8 \\
8 \\
\\
\pm \\
\pm\end{array}$ & $\begin{array}{l}8 \\
8 \\
\end{array}$ & 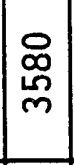 & 8 & 잉 & 1 & i & 1 & ! \\
\hline & ने & 1 & i & 1 & $i$ & 1 & i & 1 & i & 1 & i & i & i & i & i & i & 용 & i & 1 & 옹 \\
\hline & 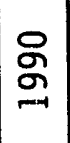 & $i$ & $i$ & $i$ & 1 & $\begin{array}{l}1 \\
1\end{array}$ & i & 1 & i & $i$ & i & $!$ & 1 & 1 & i & i & $\begin{array}{l}8 \\
8 \\
\circ \\
\sim\end{array}$ & $\begin{array}{l}0 \\
0 \\
0 \\
\\
-1\end{array}$ & I & 品 \\
\hline \multirow{4}{*}{ 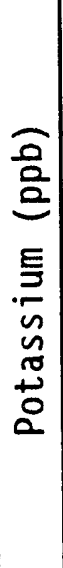 } & ฮू & $i$ & i & 1 & $\begin{array}{l}8 \\
8 \\
0 \\
0 \\
\end{array}$ & $i$ & $i$ & 1 & i & i & i & 1 & i & $\begin{array}{l}8 \\
8 \\
\\
\end{array}$ & 욤 & 号 & $i$ & i & $i$ & I \\
\hline & ๙ั & 8 & 昌 & 号 & ণ্ల్ & 足 & $\begin{array}{l}8 \\
\\
\& \\
\&\end{array}$ & $\frac{0}{\sqrt{1}}$ & 足 & 只 & 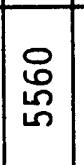 & 足 & 옹 & $\begin{array}{l}8 \\
0 \\
\end{array}$ & 용 & 只 & i & i & i & i \\
\hline & बू & 1 & i & $i$ & i & 1 & i & 1 & 1 & i & 1 & i & $i$ & 1 & i & 1 & 용 & 1 & i & 용 \\
\hline & 号 & 1 & $i$ & 1 & i & $i$ & $i$ & $i$ & i & I & 1 & 1 & i & i & 1 & 1 & $\frac{8}{\sigma}$ & 옴 & 1 & 용 \\
\hline \multirow{4}{*}{ 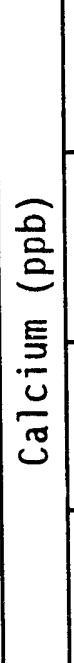 } & ğ & i & $i$ & $i$ & $i$ & i & $i$ & $i$ & $i$ & $i$ & $i$ & $i$ & $i$ & $\begin{array}{l}\stackrel{8}{\circ} \\
\stackrel{\circ}{\sim}\end{array}$ & ঃ & $\begin{array}{l}\circ \\
\stackrel{8}{0} \\
\stackrel{\sim}{\sim} \\
\end{array}$ & i & i & i & $i$ \\
\hline & テे & $\begin{array}{l}8 \\
8 \\
\\
\end{array}$ & $\begin{array}{l}8 \\
8 \\
8 \\
\\
\infty\end{array}$ & $\frac{8}{8}$ & $\begin{array}{l}8 \\
\stackrel{\circ}{\circ} \\
m\end{array}$ & $\begin{array}{l}8 \\
8 \\
8 \\
8 \\
0\end{array}$ & $\begin{array}{l}8 \\
8 \\
8 \\
\end{array}$ & $\begin{array}{l}8 \\
0 \\
6 \\
+\end{array}$ & $\begin{array}{l}8 \\
8 \\
\circ \\
0 \\
0\end{array}$ & $\begin{array}{l}8 \\
8 \\
8 \\
\\
\infty\end{array}$ & 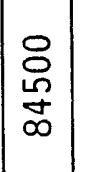 & 号 & 용 & 吕 & $\begin{array}{l}\text { 尺 } \\
\text { ల్ } \\
\text { ల్ల }\end{array}$ & $\begin{array}{l}8 \\
\stackrel{0}{n} \\
\stackrel{n}{N}\end{array}$ & $i$ & 1 & i & i \\
\hline & 㲾 & 1 & i & $i$ & i & i & $!$ & $i$ & i & $i$ & $\vdots$ & $i$ & i & $i$ & i & 1 & 号 & $\frac{8}{8}$ & i & 总 \\
\hline & 용 & 1 & i & 1 & 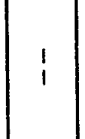 & 1 & i & 1 & $i$ & i & $i$ & $i$ & i & 1 & $i$ & 1 & $\begin{array}{l}8 \\
8 \\
0 \\
0\end{array}$ & $\begin{array}{l}\stackrel{8}{0} \\
\stackrel{n}{n} \\
\text { m }\end{array}$ & 1 & $\begin{array}{l}8 \\
8 \\
8 \\
9\end{array}$ \\
\hline & $\frac{n}{\frac{\omega}{3}}$ & 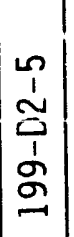 & $\left|\begin{array}{l}0 \\
1 \\
\tilde{e} \\
1 \\
g \\
g \\
\end{array}\right|$ & 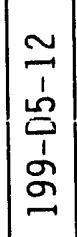 & 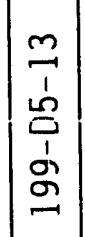 & $\left|\begin{array}{c}0 \\
1 \\
1 \\
2 \\
1 \\
1 \\
g \\
g\end{array}\right|$ & $\left|\begin{array}{c}n \\
1 \\
1 \\
2 \\
1 \\
\vdots \\
g \\
\end{array}\right|$ & \begin{tabular}{c}
0 \\
\hdashline 1 \\
$\underline{n}$ \\
1 \\
$g$ \\
$\sigma$ \\
$=$
\end{tabular} & $\begin{array}{c}2 \\
7 \\
2 \\
2 \\
1 \\
\vdots \\
g \\
2\end{array}$ & $\mid \begin{array}{c}\infty \\
1 \\
1 \\
\stackrel{2}{0} \\
1 \\
\infty \\
\sigma \\
\end{array}$ & $\begin{array}{c}a \\
1 \\
1 \\
0 \\
1 \\
\sigma \\
\sigma\end{array}$ & 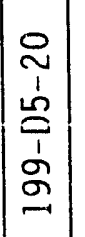 & $\begin{array}{l}m \\
1 \\
0 \\
0 \\
1 \\
\sigma \\
\sigma \\
\end{array}$ & $\begin{array}{l}0 \\
1 \\
0 \\
0 \\
1 \\
\sigma \\
\sigma \\
\sigma\end{array}$ & $\begin{array}{l}n \\
1 \\
0 \\
0 \\
\vdots \\
g \\
g \\
-1\end{array} \mid$ & $\begin{array}{l}0 \\
1 \\
\infty \\
0 \\
\vdots \\
\sigma \\
\sigma\end{array}$ & $\left|\begin{array}{c}n \\
\tilde{n} \\
1 \\
\tilde{0} \\
1 \\
\delta \\
\sigma \\
0\end{array}\right|$ & $\left|\begin{array}{c}n \\
0 \\
1 \\
\delta \\
\vdots \\
1 \\
5 \\
\delta \\
6\end{array}\right|$ & $\left|\begin{array}{l}9 \\
q \\
1 \\
b \\
o \\
1 \\
g \\
\sigma \\
6\end{array}\right|$ & 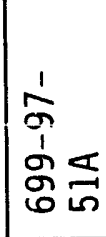 \\
\hline
\end{tabular}


Table 4-5. Anion Monitoring Results. (sheet 1 of 2)

\begin{tabular}{|c|c|c|c|c|c|c|c|c|c|c|c|c|c|c|c|c|c|c|c|c|c|}
\hline $\begin{array}{l}\stackrel{0}{ \pm} \\
\frac{2}{2} \\
\frac{ \pm}{ \pm} \\
\frac{2}{2}\end{array}$ & รั & $\begin{array}{l}\square \\
8 \\
ㅇ\end{array}$ & $\begin{array}{l}3 \\
8 \\
\end{array}$ & 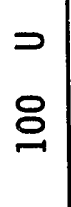 & $\frac{n}{m}$ & $\begin{array}{l}2 \\
8 \\
8\end{array}$ & $\begin{array}{l}a \\
8 \\
\circ\end{array}$ & $\begin{array}{l}\supset \\
ㅇ \\
\end{array}$ & $\begin{array}{l}\supset \\
8 \\
ㅇ\end{array}$ & $\begin{array}{l}\square \\
8 \\
ㅇ\end{array}$ & $\begin{array}{l}= \\
8 \\
ㅇ\end{array}$ & $\begin{array}{l}\square \\
8 \\
8\end{array}$ & 8 & 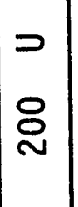 & $\begin{array}{l}D \\
\text { 옹 }\end{array}$ & 옹 & i & i & $\begin{array}{l}\square \\
\text { 옹 }\end{array}$ & $\begin{array}{l}D \\
\text { 옹 }\end{array}$ & $\begin{array}{l}\delta \\
\dot{t} \\
+\Delta \\
0\end{array}$ \\
\hline \multirow{3}{*}{ 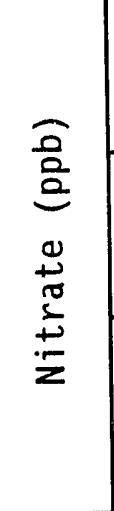 } & รั & $\frac{8}{\circ}$ & $\begin{array}{l}8 \\
\text { 足 } \\
\text { m }\end{array}$ & 용 & 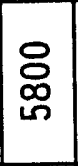 & 㤩 & 8 & 욤 & $\begin{array}{l}8 \\
8 \\
4 \\
4\end{array}$ & 용 & 足 & $\stackrel{0}{1}$ & 足 & $\underset{m}{m}$ & $\begin{array}{c}8 \\
0 \\
0 \\
-1\end{array}$ & 욤 & $i$ & i & 응 & 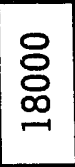 & 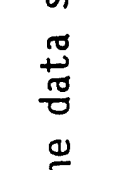 \\
\hline & 亏 & 1 & i & 1 & 1 & i & i & $!$ & $i$ & 1 & i & i & $i$ & $i$ & i & i & i & 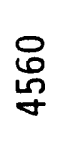 & $\frac{8}{\stackrel{8}{\sim}}$ & i & 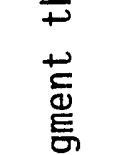 \\
\hline & 용 & $\begin{array}{l}8 \\
\text { 足 } \\
\text { ఫ్ }\end{array}$ & 1 & $\begin{array}{l}8 \\
8 \\
\Phi \\
= \\
=\end{array}$ & 1 & i & i & $i$ & $i$ & i & i & i & 응 & i & $i$ & ! & 1 & i & i & i & \begin{tabular}{l}
$\stackrel{0}{+}$ \\
$\underset{\pi}{+}$ \\
\multirow{T}{*}{}
\end{tabular} \\
\hline \multirow{2}{*}{ 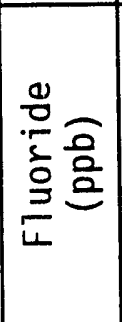 } & જ̆ & $\underline{0}$ & 号 & 只 & \begin{tabular}{|l|} 
\\
\end{tabular} & 요 & 요 & 号 & 号 & $\stackrel{0}{\stackrel{0}{\sim}}$ & 只 & $\stackrel{m}{\sim}$ & $\stackrel{n}{\sim}$ & $\begin{array}{l}7 \\
8 \\
0\end{array}$ & $\begin{array}{l}2 \\
8 \\
0\end{array}$ & $\begin{array}{l}0 \\
8\end{array}$ & i & 8 & 只 & 足 & 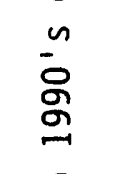 \\
\hline & 命 & 1 & i & i & 1 & $i$ & 1 & I & 1 & i & 1 & $i$ & 1 & i & i & i & $i$ & $\frac{0}{6}$ & $\underset{\sim}{\stackrel{D}{\sim}}$ & i & 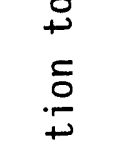 \\
\hline \multirow{3}{*}{$\begin{array}{l}\frac{0}{2} \\
\frac{2}{2} \\
\frac{0}{0} \\
\frac{0}{0} \\
\frac{0}{5}\end{array}$} & స్ & 1 & $\begin{array}{l}8 \\
8 \\
\text { D } \\
\text { N }\end{array}$ & 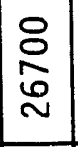 & 号 & $\begin{array}{l}\text { 웅 } \\
\text { 옹 } \\
\end{array}$ & 욤 & 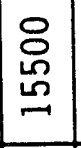 & $\begin{array}{l}\text { 응 } \\
\text { 怘 }\end{array}$ & $\frac{8}{2}$ & 只 & $\begin{array}{l}\text { O̊ } \\
\text { Ñ } \\
\text { | }\end{array}$ & $\begin{array}{c}8 \\
\mathbb{N} \\
\mathbb{N} \\
\sim\end{array}$ & $\frac{8}{m}$ & $\begin{array}{l}8 \\
\\
\text { n }\end{array}$ & 용 & i & $i$ & $\frac{8}{10}$ & $\frac{8}{2}$ & $\begin{array}{l}\text { 뮴 } \\
.\end{array}$ \\
\hline & 요 & 옹 & i & 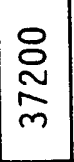 & $\vdots$ & $i$ & i & i & 1 & $i$ & i & 1 & 号 & i & $i$ & i & 1 & $i$ & $i$ & i & 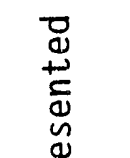 \\
\hline & $\begin{array}{l}\pi_{n} \\
\overline{0} \\
0 \\
0\end{array}$ & $\frac{8}{\tilde{N}}$ & I & 怘 & i & $i$ & 1 & i & $i$ & i & $i$ & i & 号 & $!$ & i & 1 & i & $\begin{array}{l}0 \\
\& \\
\infty \\
\& \\
\&\end{array}$ & $\begin{array}{l}8 \\
8 \\
8 \\
\end{array}$ & $\frac{8}{\approx}$ & 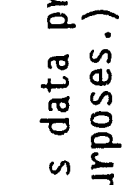 \\
\hline & $\frac{\omega}{3}$ & $\begin{array}{l}n \\
1 \\
\tilde{~} \\
0 \\
1 \\
g \\
\sigma \\
\end{array}$ & 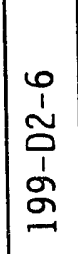 & $\begin{array}{l}\simeq \\
1 \\
1 \\
0 \\
1 \\
5 \\
2\end{array}$ & 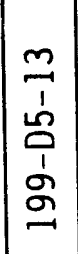 & 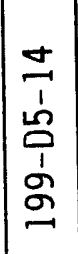 & 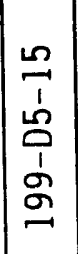 & 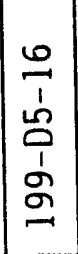 & $\begin{array}{l}2 \\
1 \\
1 \\
0 \\
1 \\
0 \\
2 \\
-1\end{array}$ & \begin{tabular}{c}
$\infty$ \\
\hdashline 1 \\
$n$ \\
0 \\
1 \\
$\sigma$ \\
$\sigma$
\end{tabular} & $\begin{array}{l}a \\
1 \\
1 \\
0 \\
1 \\
\sigma \\
g\end{array}$ & $\mid \begin{array}{c}0 \\
1 \\
1 \\
0 \\
1 \\
1 \\
\sigma \\
\end{array}$ & $\begin{array}{l}m \\
1 \\
0 \\
0 \\
1 \\
\sigma \\
g \\
-1\end{array}$ & $\begin{array}{c}0 \\
1 \\
0 \\
9 \\
1 \\
\vdots \\
g \\
-\end{array}$ & $\begin{array}{l}n \\
1 \\
0 \\
0 \\
1 \\
g \\
g \\
-1\end{array}$ & $\begin{array}{l}0 \\
1 \\
0 \\
0 \\
1 \\
\vdots \\
9 \\
-1 \\
\end{array}$ & 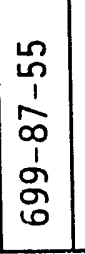 & $\begin{array}{l}\text { n } \\
1 \\
1 \\
o \\
1 \\
\vdots \\
g \\
0\end{array}$ & $\begin{array}{l}\text { g } \\
+ \\
1 \\
0 \\
o \\
1 \\
5 \\
g \\
0\end{array}$ & $\begin{array}{l}5 \\
5 \\
1 \\
1 \\
5 \\
1 \\
5 \\
9 \\
0\end{array}$ & 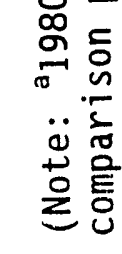 \\
\hline
\end{tabular}


Table 4-5. Anion Monitoring Results. (sheet 2 of 2)

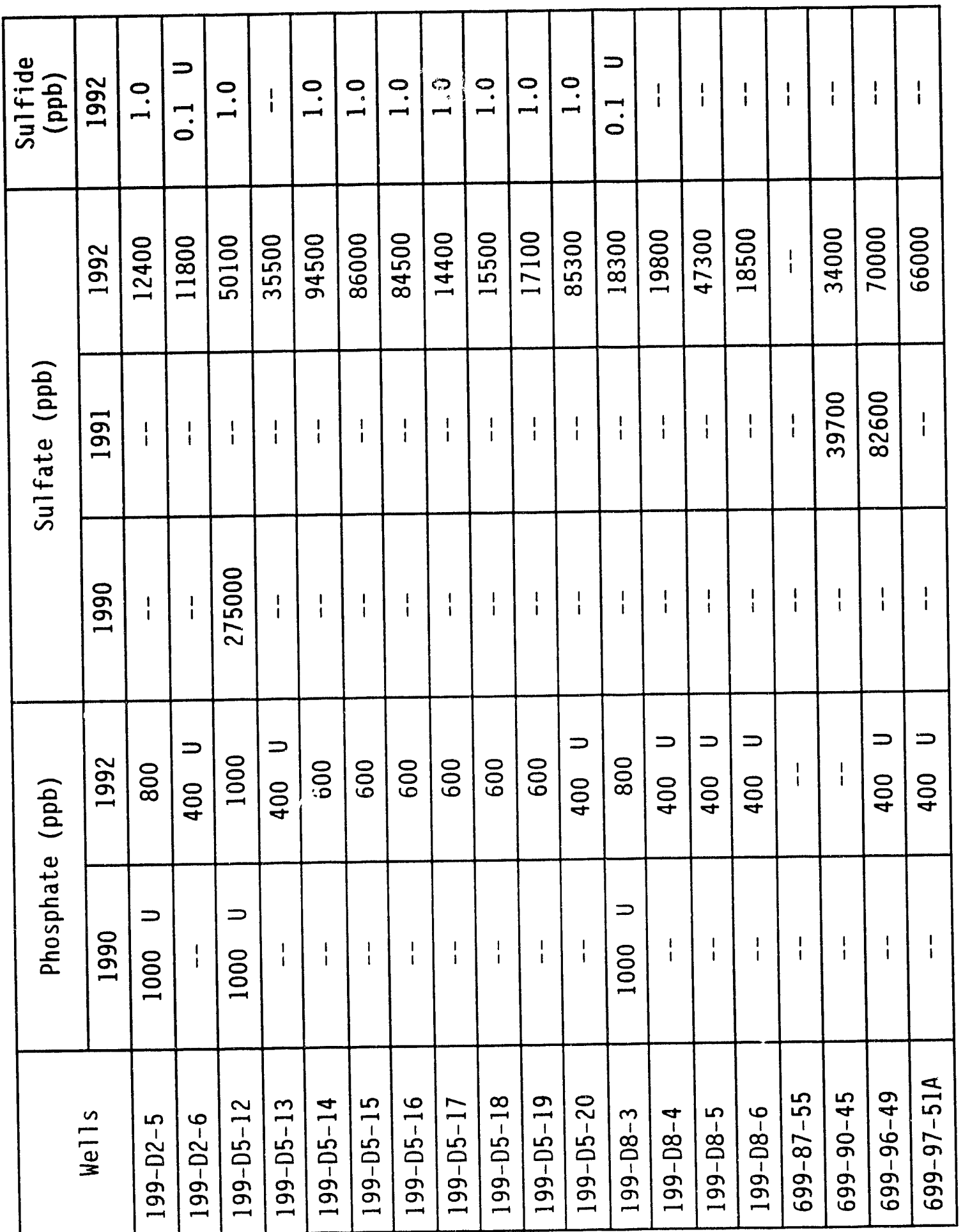


Table 4-6. Metal Monitoring Results (Unfiltered). (sheet 1 of 5)

\begin{tabular}{|c|c|c|c|c|c|c|c|c|c|c|c|c|c|c|c|c|c|c|c|c|}
\hline 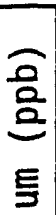 & ğ & 1 & 1 & 1 & $\begin{array}{l}\vec{D} \\
0 \\
\dot{m}\end{array}$ & 1 & i & 1 & 1 & 1 & 1 & i & i & $\begin{array}{l}D \\
0 \\
\dot{m}\end{array}$ & $\begin{array}{c}D \\
0 \\
\dot{m}\end{array}$ & $\begin{array}{c}D \\
0 \\
\dot{m}\end{array}$ & 1 & 1 & 1 & 1 \\
\hline 产 & รั & $\begin{array}{l}\infty \\
\dot{0}\end{array}$ & $\ddot{\sigma}$ & $\hat{0}$ & $\begin{array}{c}D \\
0 \\
\dot{m}\end{array}$ & $\dot{0}$ & $\begin{array}{l}9 \\
\dot{0}\end{array}$ & $\dot{0}$ & $\dot{0}$ & $\begin{array}{l}9 \\
0\end{array}$ & $\begin{array}{l}9 \\
0\end{array}$ & $\begin{array}{l}\infty \\
0\end{array}$ & $\begin{array}{l}9 \\
0\end{array}$ & $\begin{array}{c} \\
0 \\
\dot{m}\end{array}$ & $\begin{array}{l} \\
0 \\
\dot{m}\end{array}$ & $\begin{array}{l}D \\
0 \\
\dot{m}\end{array}$ & i & i & 1 & 1 \\
\hline \multirow{4}{*}{$\begin{array}{l}\frac{a}{2} \\
\frac{2}{2} \\
\text { E } \\
\frac{2}{2} \\
\frac{0}{0}\end{array}$} & รั & I & 1 & i & $\begin{array}{l}0 \\
\tilde{0}\end{array}$ & $!$ & 1 & $!$ & ! & 1 & 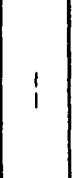 & 1 & i & $\stackrel{0}{\therefore}$ & $\begin{array}{l}\circ \\
\dot{g} \\
\dot{q}\end{array}$ & $\begin{array}{c}D \\
0 \\
\dot{v} \\
\dot{v}\end{array}$ & 1 & 1 & 1 & ! \\
\hline & รั & $\begin{array}{l}\sigma \\
\sigma\end{array}$ & $\begin{array}{l}? \\
\text { مٌ }\end{array}$ & $\begin{array}{l}\text { ? } \\
\dot{0}\end{array}$ & $\begin{array}{l}\infty \\
\tilde{\sigma}\end{array}$ & $\begin{array}{l}\circ \\
\dot{\circ}\end{array}$ & $\begin{array}{l}\text { nf } \\
\infty \\
\infty\end{array}$ & $\begin{array}{l}n \\
\infty \\
\infty \\
\infty\end{array}$ & $\stackrel{g}{m}$ & $\begin{array}{l}a \\
0 \\
0 \\
0\end{array}$ & $\begin{array}{l}\sim \\
\infty \\
\infty\end{array}$ & $\stackrel{\sim}{\sim}$ & $\begin{array}{l}m \\
\approx \\
\simeq\end{array}$ & $\stackrel{m}{\sim}$ & $\begin{array}{l}\infty \\
\stackrel{0}{n} \\
\end{array}$ & $\stackrel{m}{\sim}$ & 1 & 1 & ! & i \\
\hline & $\vec{\sigma}$ & i & 1 & I & 1 & i & i & 1 & 1 & I & 1 & $!$ & 1 & 1 & I & i & $\begin{array}{l}\tilde{O} \\
\dot{0}\end{array}$ & i & $\begin{array}{l}8 \\
0 \\
0\end{array}$ & $\begin{array}{l}\infty \\
0 \\
0 \\
0\end{array}$ \\
\hline & 용 & 1 & $i$ & 1 & ! & 1 & i & ! & 1 & i & 1 & 1 & 1 & 1 & $i$ & 1 & $\begin{array}{l}\tilde{O} \\
\dot{0}\end{array}$ & $\begin{array}{l}\tilde{0} \\
0\end{array}$ & ! & $\begin{array}{l}\infty \\
\dot{0} \\
\dot{0}\end{array}$ \\
\hline \multirow{2}{*}{ 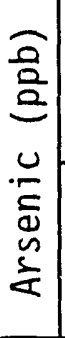 } & ร్ & $i$ & i & i & $\begin{array}{l}a \\
0 \\
0 \\
0\end{array}$ & 1 & i & 1 & 1 & 1 & 1 & 1 & 1 & $\begin{array}{l}\supset \\
0 \\
0 \\
\text { م }\end{array}$ & $\begin{array}{l} \\
0 \\
0 \\
\end{array}$ & $\begin{array}{l}0 \\
0 \\
0 \\
0\end{array}$ & ! & 1 & 1 & 1 \\
\hline & รั & $\stackrel{\infty}{\sim}$ & $\begin{array}{l}0 \\
\sim \\
\sim\end{array}$ & $\tilde{-i}$ & $\begin{array}{c}\square \\
0 \\
0\end{array}$ & N & $\hat{m}$ & $\vec{m}$ & $\stackrel{n}{\sim}$ & $\begin{array}{l}\infty \\
\sim \\
\sim\end{array} \mid$ & $\begin{array}{l}9 \\
\sim\end{array}$ & $\vec{m}$ & 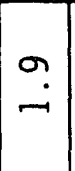 & $\begin{array}{l} \\
0 \\
0 \\
\text { ن }\end{array}$ & $\begin{array}{l}0 \\
0 \\
\dot{0}\end{array}$ & $\begin{array}{c}D \\
0 \\
\dot{0}\end{array}$ & i & I & $i$ & i \\
\hline \multirow{2}{*}{ 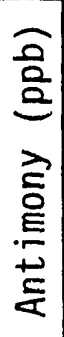 } & gू & $i$ & I & 1 & $\begin{array}{l} \\
\text { 옹 }\end{array}$ & 1 & 1 & $\begin{array}{l}1 \\
1\end{array}$ & $i$ & i & 1 & ! & 1 & $\begin{array}{l}\supset \\
\stackrel{\circ}{\sim}\end{array}$ & $\begin{array}{l} \\
\stackrel{\circ}{\circ}\end{array}$ & $\begin{array}{l}3 \\
\text { 옹 }\end{array}$ & 1 & i & i & 1 \\
\hline & 亏ू & $\stackrel{\sim}{0}$ & $\overrightarrow{\dot{m}}$ & $\begin{array}{l}m \\
\dot{0} \\
-1\end{array}$ & $\begin{array}{l} \\
\\
\end{array}$ & $\begin{array}{c}n \\
\dot{0} \\
-\end{array}$ & $\stackrel{\sim}{\dot{0}}$ & $\begin{array}{l}m \\
0 \\
0\end{array}$ & $\begin{array}{l}m \\
0 \\
0\end{array}$ & $\begin{array}{c}\sim \\
0 \\
0\end{array}$ & $\stackrel{\sim}{\sim}$ & $\begin{array}{c}\sim \\
0 \\
0\end{array} \mid$ & $\begin{array}{l}\tilde{m} \\
\dot{m}\end{array}$ & $\begin{array}{l}د \\
\text { 엉 }\end{array}$ & $\begin{array}{l}\supset \\
\text { 尺 } \\
\sim\end{array}$ & $\begin{array}{l}D \\
\text { 음 }\end{array}$ & 1 & 1 & 1 & 1 \\
\hline & $\frac{n}{\frac{\Phi}{3}}$ & $\begin{array}{l}n \\
1 \\
\widetilde{1} \\
0 \\
1 \\
\sigma \\
\end{array}$ & $\begin{array}{l}0 \\
1 \\
\widetilde{\alpha} \\
1 \\
o \\
\sigma \\
=\end{array}$ & $\begin{array}{c}\sim \\
1 \\
1 \\
2 \\
0 \\
1 \\
\sigma \\
\sigma \\
-1\end{array}$ & $\begin{array}{l}m \\
1 \\
1 \\
0 \\
1 \\
5 \\
5 \\
=\end{array} \mid$ & 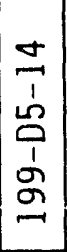 & 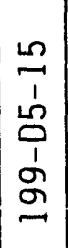 & $\begin{array}{l}0 \\
1 \\
1 \\
0 \\
1 \\
\sigma \\
\sigma \\
-\end{array}$ & $\begin{array}{l}7 \\
1 \\
5 \\
0 \\
1 \\
g \\
g \\
-1\end{array}$ & $\left|\begin{array}{c}\infty \\
1 \\
1 \\
0 \\
1 \\
0 \\
g \\
\end{array}\right|$ & $\begin{array}{l}9 \\
1 \\
1 \\
0 \\
1 \\
1 \\
5 \\
\Omega\end{array}$ & $\mid \begin{array}{l}0 \\
1 \\
1 \\
0 \\
1 \\
0 \\
5 \\
-\end{array}$ & $\begin{array}{l}n \\
1 \\
0 \\
0 \\
1 \\
\delta \\
\sigma \\
-1\end{array}$ & $\begin{array}{l}+ \\
1 \\
0 \\
0 \\
1 \\
g \\
g\end{array}$ & $\left|\begin{array}{l}n \\
1 \\
0 \\
0 \\
1 \\
1 \\
g \\
n \\
-1\end{array}\right|$ & 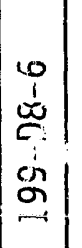 & $\begin{array}{c}0 \\
1 \\
1 \\
\infty \\
1 \\
1 \\
0 \\
0\end{array}$ & $\begin{array}{l}0 \\
0 \\
1 \\
8 \\
0 \\
1 \\
8 \\
0 \\
0\end{array}$ & 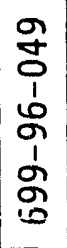 & $\begin{array}{c}5 \\
5 \\
1 \\
1 \\
\sigma \\
1 \\
0 \\
0 \\
0 \\
0\end{array}$ \\
\hline
\end{tabular}


Table 4-6. Metal Monitoring Results (Unfiltered). (sheet 2 of 5)

\begin{tabular}{|c|c|c|c|c|c|c|c|c|c|c|c|c|c|c|c|c|c|c|c|c|}
\hline 을 & รั & I & 1 & $\frac{1}{1}$ & $\begin{array}{l}\supset \\
0 \\
\stackrel{N}{0}\end{array}$ & I & i & 1 & i & 1 & $i$ & i & ! & $\begin{array}{l}\square \\
0 \\
\dot{D}\end{array}$ & $\begin{array}{l}D \\
0 \\
\dot{N}\end{array}$ & $\begin{array}{l}\square \\
0 \\
\dot{N}\end{array}$ & 1 & i & i & i \\
\hline $\begin{array}{l}\frac{1}{0} \\
\text { 응 } \\
0\end{array}$ & §ั & $\stackrel{\sim}{m}$ & $\begin{array}{l}0 \\
\text { in }\end{array}$ & $\dot{r}$ & $\begin{array}{l}P \\
0 \\
\dot{N}\end{array}$ & or & $\dot{m}$ & $\begin{array}{l}0 \\
\dot{\sim}\end{array}$ & $\underset{\sim}{m}$ & $\stackrel{m}{a}$ & $\begin{array}{l}0 \\
\dot{N}\end{array}$ & $\begin{array}{l}9 \\
\dot{\theta}\end{array}$ & $\begin{array}{l}0 \\
\dot{0}\end{array}$ & $\begin{array}{l}د \\
0 \\
\dot{N}\end{array}$ & $\begin{array}{l}a \\
0 \\
\dot{\sim}\end{array}$ & $\begin{array}{l}D \\
0 \\
\dot{N} \\
0\end{array}$ & 1 & i & 1 & ! \\
\hline \multirow{4}{*}{ 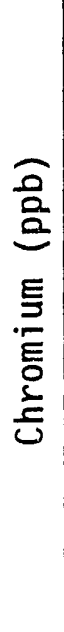 } & ळ̆ & $i$ & i & i & 엄 & 1 & $i$ & 1 & $\hat{i}$ & 1 & $i$ & i & i & $\begin{array}{l}0 \\
\dot{0}\end{array}$ & $\begin{array}{l}0 \\
\dot{m} \\
\infty\end{array}$ & $\begin{array}{l}\circ \\
\dot{0}\end{array}$ & i & I & ! & i \\
\hline & ूั & 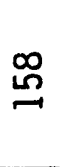 & $\bar{\approx}$ & $\stackrel{6}{\frac{\sigma}{\sigma}}$ & $\stackrel{\mathscr{Y}}{\mathscr{q}}$ & $\stackrel{m}{\vec{\sigma}}$ & 오 & 志 & $\begin{array}{l}\mathscr{0} \\
\infty \\
\infty\end{array}$ & $\vec{m}$ & กี & ฏ & $\stackrel{n}{=}$ & $\begin{array}{l}0 \\
\stackrel{\sim}{\sim}\end{array}$ & $\begin{array}{l}\infty \\
\dot{\Psi}\end{array}$ & 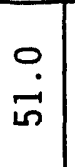 & í & 1 & i & i \\
\hline & बू & 1 & i & i & i & i & i & I & i & i & $i$ & i & i & i & I & 1 & I & I & $\begin{array}{l}0 \\
0 \\
0\end{array}$ & $\begin{array}{l}\mathscr{O} \\
\end{array}$ \\
\hline & 용 & 1 & I & 1 & $i$ & $i$ & i & 1 & 1 & i & i & 1 & i & 1 & i & i & $\begin{array}{l}+ \\
0 \\
\dot{0}\end{array}$ & i & 1 & $\begin{array}{l}\text {. } \\
0 \\
0\end{array}$ \\
\hline \multirow{2}{*}{ 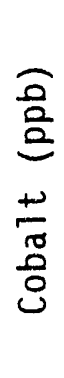 } & \%ू & $i$ & $!$ & $\mid$ & $\begin{array}{l}D \\
0 \\
\dot{D}\end{array}$ & i & 1 & 1 & 1 & ! & 1 & $\begin{array}{l}1 \\
1\end{array}$ & i & $\begin{array}{l}D \\
0 \\
0 \\
0\end{array}$ & $\begin{array}{l}D \\
0 \\
\dot{N}\end{array}$ & $\begin{array}{l}D \\
0 \\
\dot{N}\end{array}$ & i & 1 & i & $\hat{i}$ \\
\hline & ๙ั & $\ddot{m}$ & $\stackrel{\varphi}{\dot{\sigma}}$ & $\bar{\sim}$ & $\begin{array}{l}\supset \\
0 \\
\dot{N}\end{array}$ & $\grave{\sim}$ & $\begin{array}{l}m \\
\dot{m}\end{array}$ & $\hat{\sim}$ & $\hat{\sim}$ & $m$ & $\begin{array}{l}m \\
\dot{m}\end{array}$ & $\begin{array}{l}m \\
m\end{array}$ & $\begin{array}{l}0 \\
\dot{T}\end{array}$ & $\begin{array}{l}D \\
0 \\
\dot{0}\end{array}$ & $\begin{array}{l}D \\
0 \\
0 \\
\sim\end{array}$ & $\begin{array}{l}D \\
0 \\
\dot{D}\end{array}$ & i & I & 1 & i \\
\hline \multirow{2}{*}{ 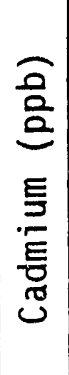 } & รั & 1 & 1 & 1 & $\begin{array}{l}0 \\
0 \\
\dot{0}\end{array}$ & $i$ & $i$ & i & ! & i & 1 & ! & 1 & $\begin{array}{c}D \\
0 \\
0 \\
-1\end{array}$ & $\begin{array}{l}D \\
0 \\
0 \\
0\end{array}$ & $\begin{array}{l}D \\
0 \\
0 \\
0\end{array}$ & i & i & i & 1 \\
\hline & \%ั & $\tilde{-}$ & $\stackrel{a}{\sim}$ & $\stackrel{\infty}{-}$ & $\begin{array}{l}0 \\
0 \\
0\end{array}$ & $\stackrel{\infty}{-}$ & $\stackrel{\infty}{-}$ & 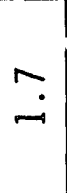 & $\stackrel{\sim}{-}$ & $\stackrel{\infty}{-}$ & $\infty$ & $\stackrel{\sim}{-}$ & $\begin{array}{c}a \\
\sim \\
\sim\end{array}$ & $\begin{array}{c}0 \\
0 \\
0 \\
0\end{array}$ & $\begin{array}{l}0 \\
0 \\
0 \\
0\end{array}$ & $\begin{array}{l}D \\
0 \\
0 \\
0\end{array}$ & i & I & 1 & i \\
\hline & $\frac{n}{\frac{\omega}{3}}$ & $\begin{array}{l}n \\
1 \\
\tilde{a} \\
1 \\
\vdots \\
\sigma \\
\sigma\end{array}$ & 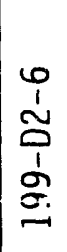 & 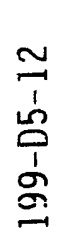 & 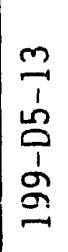 & 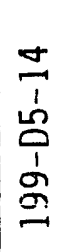 & 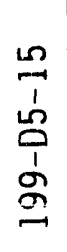 & 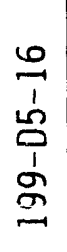 & 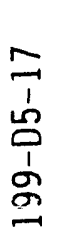 & 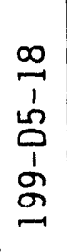 & 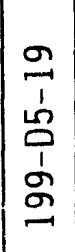 & $\begin{array}{c}0 \\
N \\
1 \\
2 \\
0 \\
1 \\
\sigma \\
\sigma \\
\end{array}$ & $\begin{array}{l}m \\
1 \\
0 \\
0 \\
1 \\
\sigma \\
\sigma \\
\end{array}$ & $\begin{array}{l}+ \\
1 \\
0 \\
0 \\
1 \\
\sigma \\
\sigma \\
-1\end{array}$ & $\begin{array}{c}n \\
1 \\
0 \\
0 \\
1 \\
1 \\
\sigma \\
-1\end{array} \mid$ & $\left|\begin{array}{l}0 \\
1 \\
0 \\
0 \\
1 \\
1 \\
g \\
g\end{array}\right|$ & $\begin{array}{c}n \\
0 \\
1 \\
\infty \\
1 \\
\delta \\
\delta \\
0\end{array}$ & $\begin{array}{l}2 \\
1 \\
1 \\
8 \\
1 \\
1 \\
\delta \\
0 \\
0\end{array}$ & $\begin{array}{l}9 \\
g \\
1 \\
b \\
o \\
1 \\
o \\
o \\
0\end{array}$ & $\begin{array}{l}\leq \\
\text { Ln } \\
1 \\
\sigma \\
1 \\
\sigma \\
\sigma \\
0\end{array}$ \\
\hline
\end{tabular}


Table 4-6. Metal Monitoring Results (Unfiltered). (sheet 3 of 5)

\begin{tabular}{|c|c|c|c|c|c|c|c|c|c|c|c|c|c|c|c|c|c|c|c|c|}
\hline \multirow{2}{*}{ 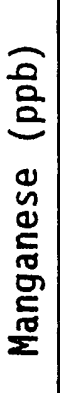 } & ふু & & & & $\begin{array}{l}a \\
0 \\
0 \\
0\end{array}$ & & & & & & & & & $\begin{array}{c}0 \\
\dot{m}\end{array} \mid$ & $\begin{array}{l}0 \\
\dot{\Xi} \\
-\end{array}$ & $\begin{array}{l}\square \\
0 \\
0 \\
0\end{array}$ & & & & \\
\hline & รั & $\stackrel{0}{\doteq}$ & $\stackrel{m}{m}$ & $\stackrel{\infty}{\dot{\sigma}}$ & $\begin{array}{c}D \\
0 \\
0 \\
\sim\end{array}$ & $\begin{array}{l}\infty \\
\infty \\
\infty\end{array}$ & $\begin{array}{l}+ \\
\check{\sigma}\end{array}$ & $\begin{array}{l}\infty \\
\infty \\
\infty\end{array}$ & 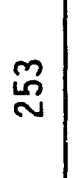 & $\begin{array}{l}\stackrel{\dot{v}}{\sim} \\
\vec{\sim}\end{array}$ & $\begin{array}{l}0 \\
\dot{m}\end{array}$ & $\ddot{\dot{m}}$ & $\begin{array}{l}m \\
\dot{m}\end{array}$ & $\begin{array}{l}\infty \\
\grave{\sim}\end{array}$ & $\begin{array}{l}n \\
\tilde{N}\end{array}$ & \begin{tabular}{l}
$m$ \\
$\dot{d}$ \\
\multirow{\sim}{*}{$\mid$}
\end{tabular} & 1 & i & 1 & 1 \\
\hline \multirow{4}{*}{ 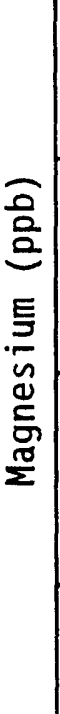 } & m & $!$ & 1 & $i$ & 号 & i & 1 & i & $i$ & I & i & i & $i$ & 용 & 옹 & $\stackrel{0}{\stackrel{n}{2}}$ & 1 & 1 & 1 & i \\
\hline & ฐั & $\begin{array}{l}\text { 욤 } \\
\text { ले }\end{array}$ & $\stackrel{8}{\circ}$ & $\frac{8}{\infty}$ & $\underset{\sim}{\tilde{N}}$ & $\begin{array}{c}8 \\
0 \\
0 \\
-1\end{array}$ & 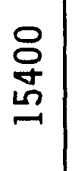 & $\begin{array}{l}8 \\
\stackrel{ }{\beth} \\
=\end{array}$ & 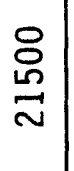 & $\begin{array}{l}\circ \\
\stackrel{8}{\circ} \\
\stackrel{0}{\sim} \\
\text {. }\end{array}$ & $\begin{array}{l}8 \\
\stackrel{8}{\sim} \\
\stackrel{\sim}{1}\end{array}$ & 吕 & $\stackrel{ }{=}$ & 농 & $\begin{array}{l}\text { ஓి } \\
\text { \& } \\
\infty\end{array}$ & $\stackrel{R}{\Sigma}$ & 1 & i & I & 1 \\
\hline & $\vec{\sigma}$ & 1 & $i$ & 1 & i & 1 & $i$ & 1 & $i$ & 1 & $!$ & i & 1 & 1 & 1 & $i$ & $\begin{array}{l}\infty \\
\dot{0}\end{array}$ & $\Xi$ & I & $\stackrel{0}{\dot{\Xi}}$ \\
\hline & 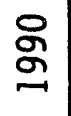 & $i$ & i & 1 & i & i & 1 & i & i & $i$ & 1 & 1 & 1 & i & i & i & $\begin{array}{l}+ \\
\dot{0}\end{array}$ & $\begin{array}{l}+ \\
\beth\end{array}$ & 1 & $\stackrel{\text { n }}{\beth}$ \\
\hline \multirow{4}{*}{$\begin{array}{l}\frac{0}{2} \\
\text { 응 } \\
\delta \\
\vdots\end{array}$} & ğ & $!$ & $\begin{array}{l}1 \\
1\end{array}$ & 1 & ৪্ল & i & I & 1 & 1 & i & I & i & 1 & $\stackrel{\infty}{\circ}$ & 怘 & 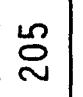 & 1 & 1 & 1 & 1 \\
\hline & รั & $\stackrel{\mathscr{m}}{\sim}$ & $\underset{\approx}{\approx}$ & $\stackrel{n}{n}$ & $\stackrel{m}{\sim}$ & $\exists$ & $\widehat{\widehat{N}}$ & $\stackrel{0}{0}$ & $\begin{array}{c}m \\
m \\
\infty \\
+\end{array}$ & $\hat{\tilde{\Omega}}$ & $\underset{⿱}{\stackrel{0}{\simeq}}$ & $\underset{0}{\tilde{O}}$ & $\begin{array}{l}0 \\
0 \\
0\end{array}$ & 욤 & $\stackrel{\mathbb{D}}{\sim}$ & 芯 & $i$ & i & $i$ & 1 \\
\hline & बू & 1 & $i$ & $i$ & $i$ & 1 & i & 1 & 1 & $!$ & $!$ & 1 & $!$ & 1 & 1 & i & $\begin{array}{l}0 \\
0\end{array} \mid$ & 1 & $\begin{array}{l}+ \\
0 \\
0\end{array}$ & $\begin{array}{l}\text { Oे } \\
\dot{0}\end{array}$ \\
\hline & 号 & $i$ & 1 & i & i & $i$ & 1 & 1 & 1 & i & 1 & 1 & 1 & 1 & 1 & i & $\begin{array}{l}\widetilde{0} \\
0\end{array}$ & $\stackrel{\sim}{-}$ & 1 & $\begin{array}{l}m \\
0 \\
0\end{array}$ \\
\hline & $\frac{\sim}{\frac{\omega}{2}}$ & 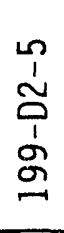 & $\begin{array}{l}0 \\
1 \\
\sim \\
1 \\
1 \\
\Omega \\
\Omega\end{array}$ & 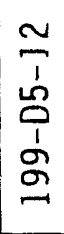 & 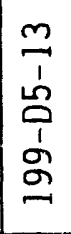 & 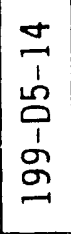 & $\begin{array}{c}n \\
1 \\
n \\
0 \\
0 \\
\delta \\
\sigma \\
\sigma \\
-\end{array}$ & 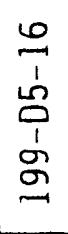 & $\begin{array}{l}a \\
1 \\
\dot{2} \\
0 \\
1 \\
g \\
\sigma \\
-1\end{array}$ & 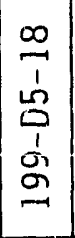 & $\begin{array}{c}9 \\
1 \\
1 \\
0 \\
1 \\
\vdots \\
5 \\
9\end{array} \mid$ & $\begin{array}{c}0 \\
1 \\
1 \\
0 \\
0 \\
1 \\
\vdots \\
\vdots \\
=\end{array} \mid$ & $\begin{array}{c}m \\
1 \\
0 \\
0 \\
1 \\
\overline{1} \\
\sigma \\
-\end{array}$ & 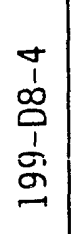 & $\left|\begin{array}{c}n \\
1 \\
0 \\
0 \\
1 \\
1 \\
5 \\
5 \\
-1\end{array}\right|$ & $\begin{array}{l}0 \\
1 \\
0 \\
0 \\
1 \\
\frac{1}{\sigma} \\
\sigma \\
=\end{array}$ & $\begin{array}{c}n \\
0 \\
1 \\
\infty \\
1 \\
1 \\
0 \\
0 \\
0\end{array}$ & $\begin{array}{c}0 \\
0 \\
1 \\
0 \\
o \\
1 \\
5 \\
5 \\
0\end{array}$ & $\begin{array}{c}9 \\
5 \\
1 \\
o \\
o \\
1 \\
5 \\
\sigma \\
6\end{array}$ & $\mid \begin{array}{c}5 \\
\text { is } \\
1 \\
\hat{~} \\
1 \\
1 \\
6 \\
6\end{array}$ \\
\hline
\end{tabular}


Table 4-6. Metal Monitoring Results (Unfiltered). (sheet 4 of 5)

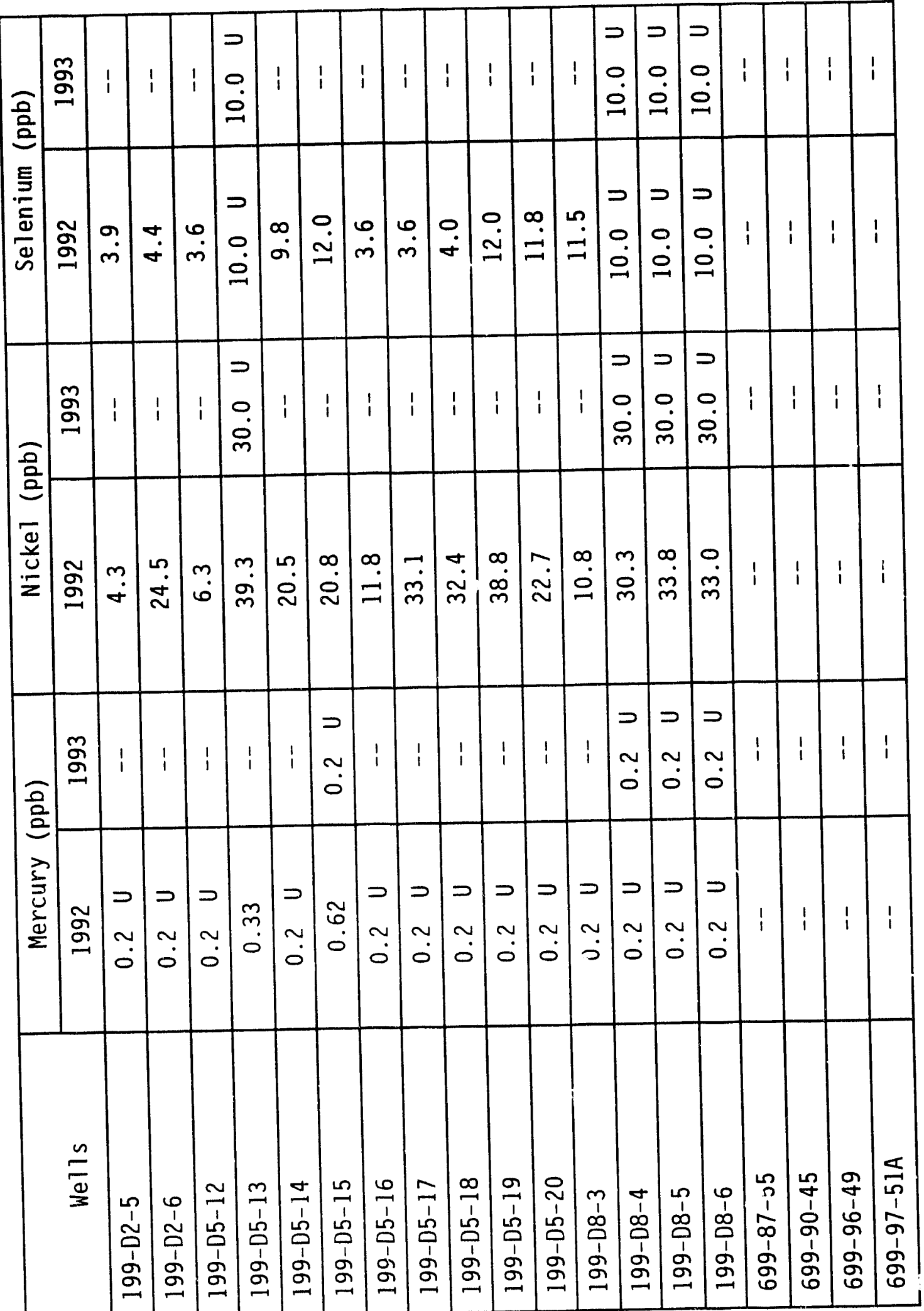


Table 4-6. Metal Monitoring Results (Unfiltered). (sheet 5 of 5 )

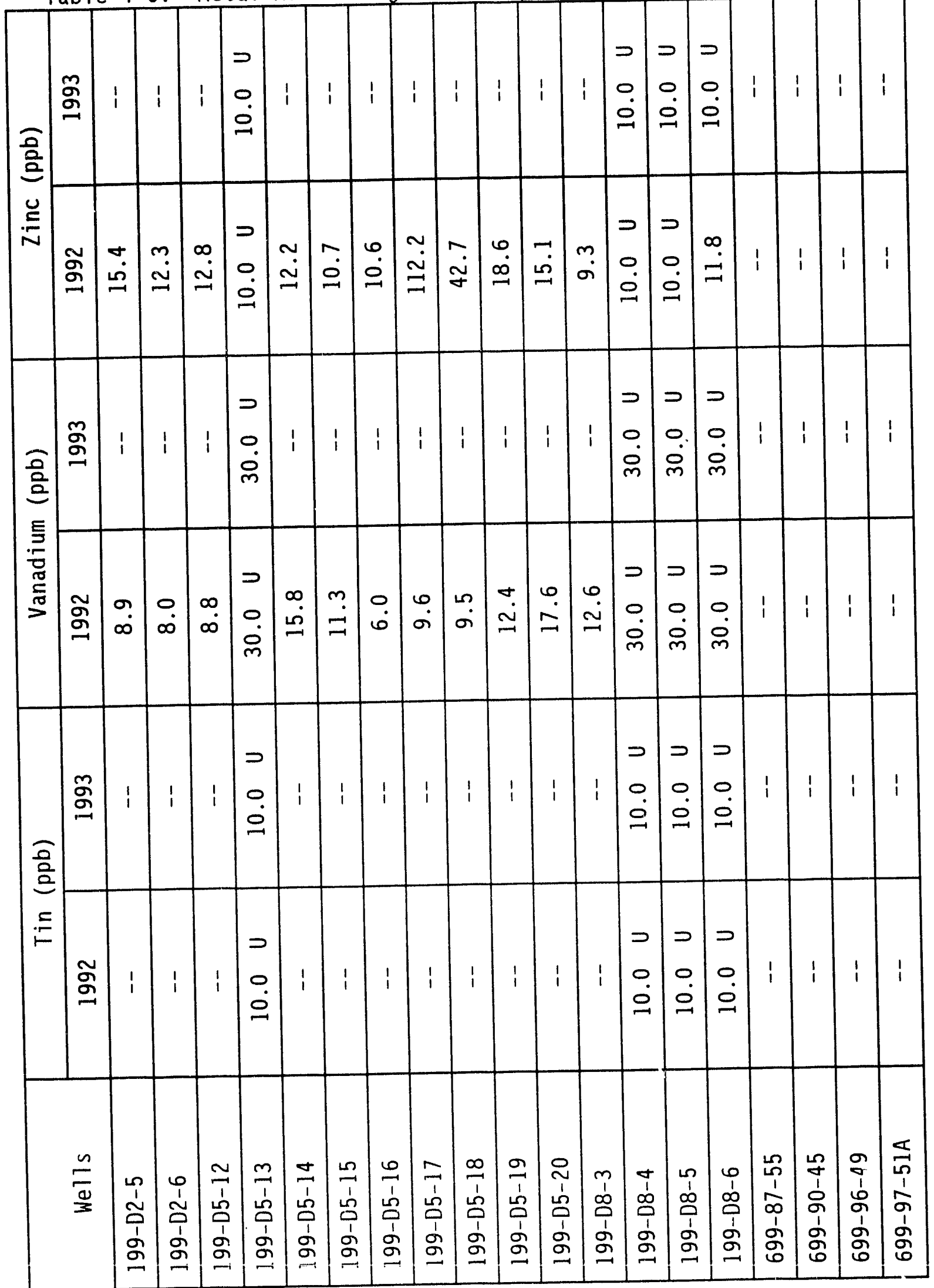


Table 4-7. Radionuclide Monitoring Results. (sheet 1 of 2)

\begin{tabular}{|c|c|c|c|c|c|c|c|c|c|c|c|c|c|c|c|c|c|c|c|}
\hline \multirow{3}{*}{ 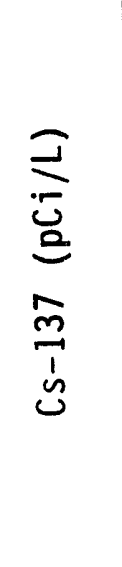 } & శ్ & $i$ & $i$ & 1 & $\begin{array}{l}\infty \\
\dot{p} \\
1\end{array}$ & $i$ & 1 & 1 & 1 & 1 & 1 & i & $i$ & $\begin{array}{l}\dot{\sigma} \\
\dot{\tau}\end{array}$ & $\begin{array}{l}1 \\
1\end{array}$ & 1 & 1 & $i$ & 1 \\
\hline & बे & ণ. & $i$ & : & 1 & 1 & $\mathrm{i}$ & 1 & 1 & 1 & 1 & 1 & $\begin{array}{l} \pm \\
\dot{T}\end{array}$ & \begin{tabular}{l|l}
1 & 1 \\
1
\end{tabular} & \begin{tabular}{l|l}
1 & 1
\end{tabular} & $\mid \begin{array}{c}0 \\
\stackrel{\infty}{1} \\
0 \\
0\end{array}$ & 1 & 1 & $\begin{array}{l}8 \\
\dot{\sim} \\
i\end{array}$ \\
\hline & 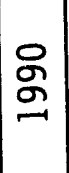 & $\begin{array}{c}\text { @ } \\
-1\end{array}$ & $i$ & $\underset{\sim}{\stackrel{ \pm}{i}}$ & 1 & $i$ & 1 & $i$ & 1 & 1 & 1 & 17 & $\stackrel{\Xi}{\sim}$ & $1 \mid \begin{array}{l}c \\
c \\
a \\
c\end{array}$ & \begin{tabular}{l|l}
0 & \\
& $\tilde{m}$ \\
& $m$ \\
1 & $m$
\end{tabular} & 1 & 1 & 1 & $\begin{array}{l}1 \\
1\end{array}$ \\
\hline \multirow{3}{*}{$\begin{array}{l}\text { ב } \\
: \overrightarrow{0} \\
0 \\
0 \\
0 \\
0 \\
0\end{array}$} & જั & $i$ & 1 & 1 & $\mid \begin{array}{c}0 \\
0 \\
0 \\
1 \\
1\end{array}$ & 1 & 1 & $i$ & $i$ & 1 & 1 & 1 & $1 \mid \begin{array}{l}c \\
1 \\
0\end{array}$ & 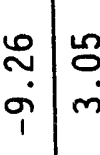 & بـ & $\mid \begin{array}{l}\infty \\
\infty \\
-i\end{array}$ & 1 & $\mid \begin{array}{l}0 \\
\stackrel{2}{0} \\
\stackrel{1}{1}\end{array}$ & 1 \\
\hline & ฮี & ?. & $i$ & $\stackrel{\varphi}{-}$ & 1 & 1 & 1 & $i$ & 1 & i & $i$ & $i$ & $\begin{array}{l}0 \\
\dot{1} \\
\end{array}$ & ! & \begin{tabular}{l|l}
1 & 1
\end{tabular} & $i$ & 1 & 1 & 1 \\
\hline & 용 & $\begin{array}{l}\dot{\sim} \\
\dot{\sim}\end{array}$ & $i$ & $\dot{m}$ & 1 & 1 & 1 & 1 & 1 & 1 & 1 & 1 & \begin{tabular}{ll|l}
$\infty$ & 1 \\
- & 1
\end{tabular} & 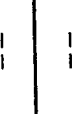 & $!$ & 1 & 1 & 1 & 1 \\
\hline \multirow{2}{*}{ 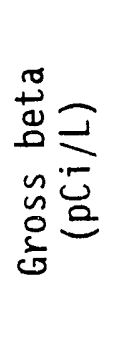 } & รั & $\stackrel{\sim}{0}$ & $\dot{0}$ & 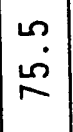 & $\dot{\vec{\sigma}}$ & $\dot{+}$ & $\tilde{\sigma}$ & $\begin{array}{l}9 \\
0\end{array}$ & $\begin{array}{l}n \\
\infty\end{array}$ & $\stackrel{0}{r}$ & $\hat{\dot{\sigma}}$ & \begin{tabular}{c|c}
$m$ & $c$ \\
$m$ & $s$
\end{tabular} & \begin{tabular}{l|l}
0 \\
$\dot{0}$ \\
&
\end{tabular} & $\begin{array}{lll}\stackrel{n}{n} & \sigma \\
\dot{n}\end{array}$ & $\stackrel{+}{\sim}$ & 1 & $i$ & 1 & 1 \\
\hline & 욤 & $\dot{m}$ & 1 & $\overrightarrow{\dot{m}}$ & $i$ & 1 & 1 & i & 1 & 1 & i & 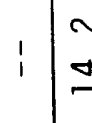 & 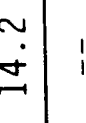 & i & 1 & 1 & 1 & 1 & $i$ \\
\hline 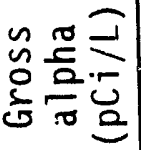 & જ̆ & n & $\dot{0}$ & $\ddot{0}$ & $\begin{array}{l}\infty \\
0 \\
0\end{array}$ & $\tilde{\sim}$ & $\because$ & $\tilde{\sim}$ & $\begin{array}{l}0 \\
\dot{\sigma} \\
\dot{\sigma}\end{array}$ & o & $\begin{array}{c}0 \\
\sim \\
\sim\end{array}$. & $\stackrel{0}{\circ}$ & \begin{tabular}{l|l} 
\\
\end{tabular} & •.|l & \begin{tabular}{l|l} 
\\
\\
0
\end{tabular} & $i$ & 1 & $i$ & 1 \\
\hline \multicolumn{2}{|c|}{$\frac{n}{\frac{\omega}{3}}$} & $\begin{array}{l}0 \\
1 \\
\tilde{a} \\
1 \\
\vdots \\
\Omega \\
\end{array}$ & $\begin{array}{l}0 \\
1 \\
\tilde{a} \\
1 \\
\vdots \\
\sigma \\
\sigma\end{array}$ & 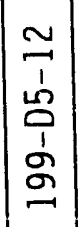 & 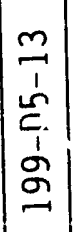 & $\begin{array}{l} \pm \\
1 \\
1 \\
0 \\
1 \\
\sigma \\
\sigma\end{array}$ & 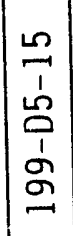 & $\mid \begin{array}{l}0 \\
1 \\
1 \\
0 \\
1 \\
\Omega \\
\Omega \\
-1\end{array}$ & $\begin{array}{c}2 \\
1 \\
2 \\
0 \\
1 \\
o \\
\sigma \\
-1\end{array}$ & 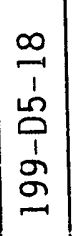 & 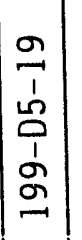 & 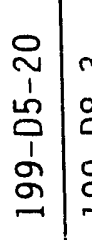 & 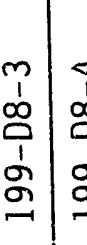 & & 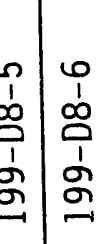 & $\mid \begin{array}{l}0 \\
1 \\
1 \\
0 \\
1 \\
\delta \\
0 \\
6\end{array}$ & 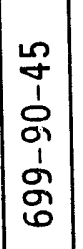 & $\left|\begin{array}{c}9 \\
1 \\
1 \\
0 \\
0 \\
\vdots \\
o \\
0\end{array}\right|$ & 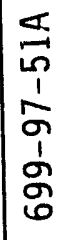 \\
\hline
\end{tabular}


Table 4-7. Radionuclide Monitoring Results. (sheet 2 of 2)

\begin{tabular}{|c|c|c|c|c|c|c|c|c|c|c|c|c|c|c|c|c|c|c|c|c|}
\hline \multirow{4}{*}{ 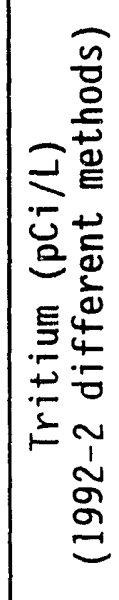 } & ภั & ஓ & 尽 & $\begin{array}{l}\text { 요 } \\
\text { 유 } \\
\infty\end{array}$ & 1 & $\stackrel{\sim}{\mathrm{m}}$ & 용 & $\begin{array}{l}\text { 尺 } \\
\text { ల్ }\end{array}$ & \begin{tabular}{l}
8 \\
8 \\
\hdashline \\
\end{tabular} & 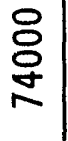 & $\begin{array}{l}8 \\
\text { 요 } \\
\text { న్ల }\end{array}$ & $\stackrel{\infty}{\sim}$ & $\begin{array}{c}\widehat{0} \\
\mathbf{m}\end{array}$ & 1 & $i$ & i & ! & 1 & 1 & 1 \\
\hline & જ̆ & $\begin{array}{l}\text { 옹 } \\
\text { 욜 }\end{array}$ & 1 & 용 & $\begin{array}{l}\dot{0} \\
\dot{\circ}\end{array}$ & I & i & 1 & 1 & 1 & $i$ & 1 & 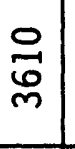 & $\begin{array}{l}n \\
\infty \\
o \\
o\end{array}$ & $\begin{array}{l}\stackrel{8}{\not} \\
\underset{\infty}{-1}\end{array}$ & $\begin{array}{c}\infty \\
\dot{\infty} \\
1\end{array}$ & 1 & $\begin{array}{l}0 \\
\stackrel{1}{=}\end{array}$ & 吕 & $\frac{\infty}{\infty}$ \\
\hline & ร్ & ! & 1 & $i$ & 1 & I & 1 & 1 & 1 & i & 1 & i & 1 & 1 & 1 & i & $\begin{array}{l}8 \\
\frac{8}{8} \\
\frac{8}{8}\end{array}$ & 음 & 욤 & ᄋ \\
\hline & 욤 & $i$ & $!$ & $!$ & I & $!$ & 1 & 1 & 1 & 1 & i & i & $i$ & 1 & I & i & 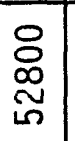 & 员 & 1 & $\begin{array}{l}8 \\
8 \\
8 \\
\end{array}$ \\
\hline \multirow{3}{*}{ 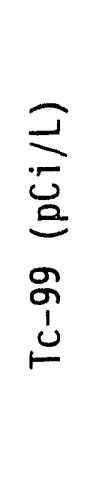 } & ภั & 1 & 1 & $i$ & $\begin{array}{l}0 \\
\dot{0}\end{array}$ & 1 & 1 & 1 & 1 & i & i & ! & i & $\begin{array}{l}\infty \\
\dot{0}\end{array}$ & $\dddot{0}$ & i & i & 1 & $!$ & \\
\hline & פू & $\tilde{0}$ & $\dot{0}^{\infty}$ & 1 & i & i & i & $i$ & i & $i$ & i & ! & $\stackrel{\overbrace{}}{-}$ & $\mathrm{i}$ & i & i & $\vec{\sim}$ & $\stackrel{m}{-}$ & $\stackrel{0}{-i}$ & $\overrightarrow{0}$ \\
\hline & 욤 & $\dot{0}$ & $\ddot{\square}$ & 1 & 1 & 1 & i & 1 & 1 & i & $i$ & 1 & $\underset{i}{\sim}$ & i & 1 & 1 & $\begin{array}{l}\dot{ } \\
\dot{m}\end{array}$ & $\vec{\sigma}$ & 1 & 1 \\
\hline 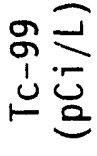 & ๙ั & $\stackrel{\sigma}{\sim}$ & $\begin{array}{l}0 \\
\dot{m}\end{array}$ & $\stackrel{0}{0}$ & $\ddot{0}$ & $\check{-}$ & ?. & $\stackrel{9}{\sim}$ & $m$ & $\stackrel{9}{0}$ & $\stackrel{9}{0}$ & $\begin{array}{l}9 \\
\dot{n}\end{array}$ & $\overrightarrow{-}$ & $\stackrel{\sim}{\sim}$ & $\dot{\theta}$ & $\begin{array}{l}m \\
\sim\end{array}$ & 1 & 1 & 1 & \\
\hline 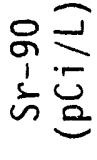 & ภั & $\dddot{0}$ & $\dddot{0}$ & $\stackrel{m}{\dot{m}}$ & $\stackrel{\sim}{0}$ & $\begin{array}{l}3 \\
0 \\
0\end{array}$ & $\stackrel{-}{-}$ & $\ddot{0}$ & ¿ & ? & $\overrightarrow{0}$ & $\begin{array}{l}+ \\
\dot{T}\end{array}$ & $\hat{m}$ & $\begin{array}{l}\overrightarrow{0} \\
\dot{0}\end{array}$ & $\begin{array}{l}\sim \\
0 \\
1\end{array}$ & $\begin{array}{l}\sim \\
0 \\
1\end{array}$ & 1 & $!$ & 1 & 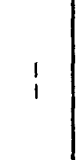 \\
\hline 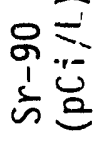 & 용 & $\dddot{0}$ & 1 & ஸ̊ & i & i & 1 & ! & $i$ & $\begin{array}{l}1 \\
1\end{array}$ & 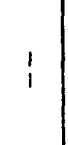 & $i$ & $\begin{array}{l}0 \\
\sim\end{array}$ & $i$ & 1 & i & $i$ & 1 & 1 & \\
\hline & $\approx$ & 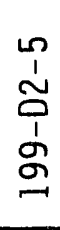 & $\begin{array}{l}0 \\
1 \\
1 \\
0 \\
1 \\
\vdots \\
g \\
\sigma\end{array}$ & 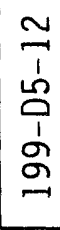 & 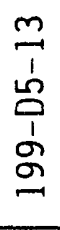 & $\begin{array}{l} \pm \\
1 \\
\text { L } \\
0 \\
\vdots \\
\stackrel{1}{\sigma}\end{array}$ & $\begin{array}{l}n \\
1 \\
2 \\
0 \\
\vdots \\
\sigma \\
\sigma\end{array}$ & $\begin{array}{l}0 \\
\stackrel{1}{\vdots} \\
\stackrel{0}{0} \\
\vdots \\
\sigma \\
\sigma \\
\square\end{array}$ & $\begin{array}{l}a \\
1 \\
\stackrel{1}{0} \\
1 \\
o \\
\sigma \\
=\end{array}$ & 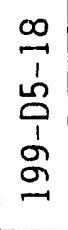 & 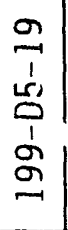 & 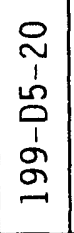 & $\begin{array}{l}m \\
1 \\
0 \\
0 \\
1 \\
2 \\
g \\
=\end{array}$ & 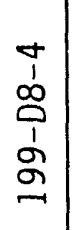 & 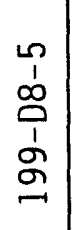 & $\begin{array}{l}0 \\
1 \\
0 \\
0 \\
1 \\
\sigma \\
\sigma \\
=\end{array}$ & $\begin{array}{l}n \\
\sim \\
1 \\
\infty \\
\infty \\
1 \\
o \\
0 \\
0\end{array}$ & $\begin{array}{l}\text { \& } \\
\vdots \\
\vdots \\
o \\
1 \\
o \\
0 \\
0\end{array}$ & $\begin{array}{l}9 \\
+ \\
1 \\
o \\
1 \\
1 \\
\delta \\
\delta\end{array}$ & ô \\
\hline
\end{tabular}


WHC-EP-0666 


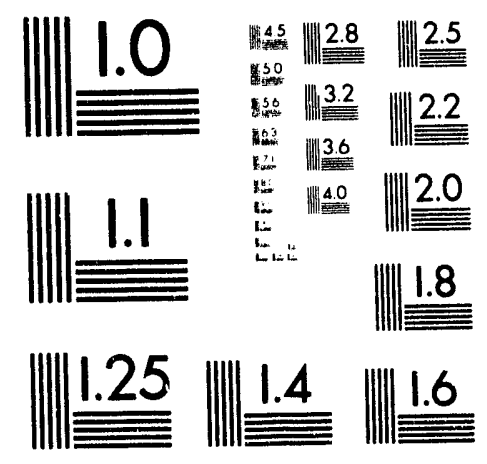



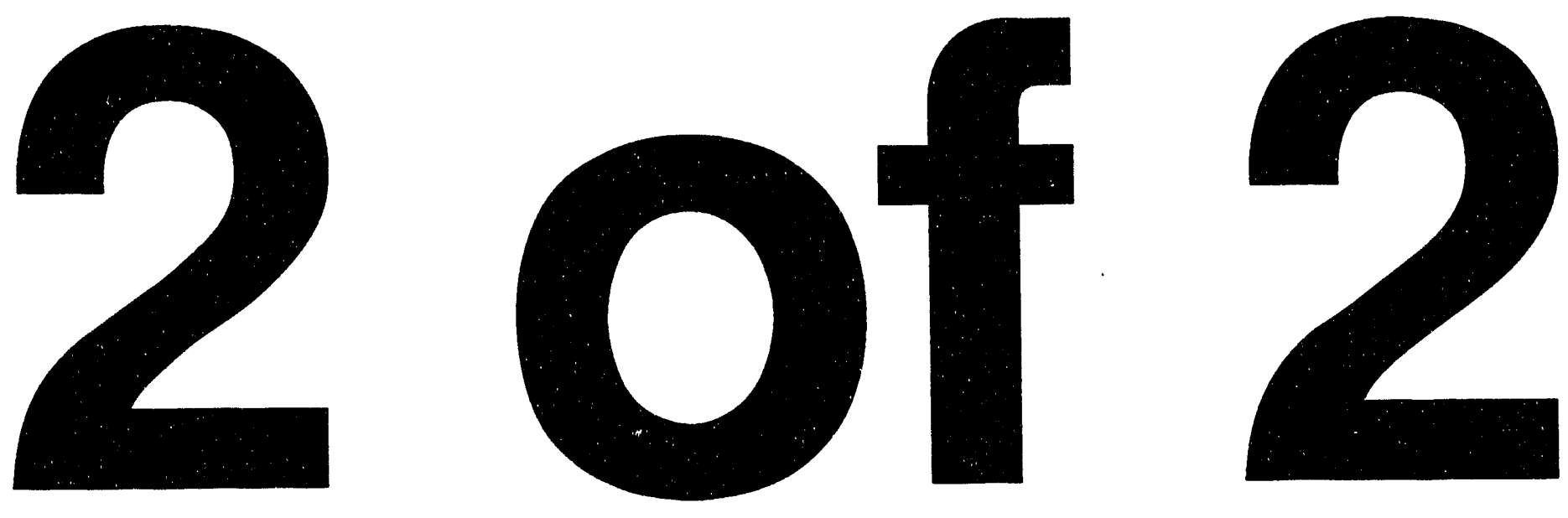


\subsection{IMPACT ASSESSMENT}

\subsection{HYDROLOGIC IMPACTS}

Pertlirbation of the local groundwater flow regime is an unlikely consequence of the average discharge rate to this site. For example, the discharge rate to the ponds is small in relation to the natural recharge to the unconfined aquifer (i.e., less than upper Cold Creek flow rate).

Additionally, natural fluctuations in water table elevation due to river stage changes will mask any small flow perturbations due to waste discharge.

The discharge event that took place in January $1993(300,000$ gal $[1,135,620 \mathrm{~L}])$ was an exception to the statement above. The effect this discharge had on the water table was detected because water table measurements were taken within a few days of the discharge. Normally, the effect on the water table would not be detected, as compared to other effects such as the changes in river stage.

\subsection{CONTAMINANT IMPACTS}

\subsubsection{One-Dimensional Flow and Transport Analysis (Analytical Methods)}

The same one-dimensional analytical method described in the Liquid Effluent Study Final Project Report (WHC 1990a) was employed to estimate the rate of moisture and contaminant movement through the soil column beneath the ponds. The method considers only flow in the vertical direction and does not allow for lateral spreading. Thus it is expected to provide migration rates that are faster than those that occur under actual conditions.

The method is based on steady-state flow conditions in the unsaturated zone and assumes a unit hydraulic gradient. The basic equation for any layer of sediments is

$$
t=L \times \theta / q
$$

where:

$t=$ time of travel through layer, sec

$L=$ thickness of 1 ayer, $\mathrm{cm}$

$\theta=$ moisture content of sediment, related to hydraulic conductivity

$\mathrm{q}=$ Darcy velocity or moisture flux in layer, $\mathrm{cm} / \mathrm{sec}$. 
The total travel time, $T$, is determined as the summation of the travel times for each of the " $i$ "layers:

$$
T=\sum_{i=1}^{n} L_{i} \times \theta_{i} / q_{i}
$$

where $n$ is the number of sediment layers. For transport calculation purposes, the soil column beneath the settling pond was treated as a single layer of coarse sand and gravel with a depth to water of approximately $66 \mathrm{ft}(20 \mathrm{~m})$ (Figure 5-1).

The relationship between hydraulic conductivity, $K$, and moisture content, $\theta$, is described graphically in Figure 5-2. These curves were derived empirically from laboratory tests on over 20 different Hanford Site sediment types and were used to establish five major sediment types, as noted in the figure.

For unsaturated flow the steady-state Darcy velocity or water flux is described by the Green-Ampt equation (Bouwer 1978, p. 253), which results in the flux, $q$, being equal to the saturated hydraulic conductivity, $k_{s}$.

The one-dimensional flow analysis embodied in equation 2 was carried out on a Symphony (a registered trademark of the Lotus Development Corporation) spreadsheet. The total travel time, T, obtained with equation 2 is divided into the vadose zone thickness to provide an estimate of the rate of moisture migration from the disposal facility to the groundwater.

To obtain an estimate of the rate of contaminant migration, the retardation factor, $R_{f}$, for each of the contaminants identified was estimated from the following approximation for Hanford soils:

$$
R_{f}=1+5 K_{d}
$$

The $K_{d}$ values were selected from Ames and Serne (1991). When the rate of moisture migration is divided by the $R_{f}$ for the contaminant of interest, the result is an estimate of the contaminant migration rate. These computations were also carried out using the Symphony spreadsheet method.

The effluent discharge rate, as described previously, is entered as liters per month in the spreadsheet computational method. Effluent volumes through 1987 listed in WHC-EP-0287, Vol. 3, were updated to include 1988 and 1989 (WHC 1989) for the Liquid Effluent Study (WHC 1990a; the same average infiltration rate was also assumed for the time period subsequent to 1989). The total volume (1iters) was divided by the corresponding operating period (months) to establish an average rate of inflow $(\mathrm{L} / \mathrm{mo})$. This effluent discharge rate was divided by the effective pond area to obtain an estimate of the average infiltration rate. Because the ponds are only partially wetted, an estimate of this area was used. 
More details and an illustrative example for application of the overall computational approach are provided in WHC (1990a).

\subsubsection{Results of Initial Analytical Solution}

(The following discussion summarizes the results from the Liquid Effluent Study Final Project Report [WHC 1990a]).

Based on general effluent characteristics and corresponding sorption parameters (Section 5.2.1) for the key constituents identified in Table 5-1, the calculated migration rates (Table 5-2) are $1.3 \mathrm{in./day}(3.4 \mathrm{~cm} / \mathrm{day}$ ) for mobile constituents (sulfate and chromium), and 0.004 to $0.012 \mathrm{in./day}$ $(0.01$ to $0.03 \mathrm{~cm} / \mathrm{day})$ for the less mobile constituents (manganese, mercury, lead, aluminum, and iron). These migration rates suggest that after a 16-year discharge period (1977 to present), and assuming a continuous average discharge rate of $5.02 E+05 \mathrm{gal} / \mathrm{mo}(1.9 \mathrm{E}+05 \mathrm{~L} / \mathrm{mo})$ (see Table $5-2$ ), the maximum depth of penetration of the less mobile constituents is 1 ess than $7 \mathrm{ft}(2 \mathrm{~m})$. Breakthrough of the mobile constituents occurs after less than 2 years (see Table 5-2).

Migration rate estimates for most of the key constituents in the effluent stream (see Table 5-2) suggest that they are retained on the soil column. Sulfate and chromium, on the other hand, would be expected to occur in vicinity groundwater; for example, based on average effluent conditions indicated in Table 5-1, maximum groundwater concentrations about five times WWQS may occur. Mitigating factors include dispersion and dilution by mixing with groundwater and, eventually, additional dilution by mixing with the nearby river water.

\subsubsection{Results of Revised Analytical Solution}

The method described in Section 5.2.1 was rerun using updated input parameters for effluent discharge rate $\left(9.9 \times 10^{+5} \mathrm{~L} / \mathrm{mo}\right)$ and the area of the settling pond $\left(1176 \mathrm{~m}^{2}\right.$ ). Five additional constituents of interest (cadmium, zinc, antimony, molybdenum, and selenium) were added to the list. In addition, the method was run using the initial solution $R_{f}$ values and a lower boundary set of $R_{f}$ values (all calculated from $\mathrm{Kd}$ values found in Ames and Serne 1991).

Based on general effluent characteristics and corresponding sorption parameters (Section 5.2.1) for the key constituents identified in Table 5-1 and additional constituents of interest, the calculated migration rates (Table 5-3) are as follows:

- $6.4 \mathrm{in./day}(16.3 \mathrm{~cm} /$ day) for mobile constituents (chromium, sulfate, antimony, molybdenum, and selenium) for both sets of $R_{f}$ values (preferred and lower bound).

- 0.03 to $0.13 \mathrm{in.} /$ day $(0.07$ to $0.33 \mathrm{~cm} /$ day) for less mobile constituents (iron, manganese, and aluminum); ranges are given as preferred to lower bound. 
- $0.04 \mathrm{in.} /$ day $(0.11 \mathrm{~cm} /$ day) for the least mobile constituents (lead, mercury, cadmium, and zinc) for both sets of $R_{f}$ values (preferred and lower bound).

These migration rates suggest that after a 16-year discharge period (January 1977 to May 1993), and assuming a continuous average discharge rate of $2.6 \mathrm{E}+05 \mathrm{gal} / \mathrm{mo}(9.9 \mathrm{E}+05 \mathrm{~L} / \mathrm{mo}$ ) (see Table 5-3), the maximum depth of penetration of the less mobile constituents would be less than $20 \mathrm{ft}(6 \mathrm{~m})$. Breakthrough of the most mobile constituents occurs after less than a half year (see Table 5-3). Breakthrough of the less mobile constituents would occur in about 17 years and the least mobile constituents would not breakthrough for over 50 years.

Migration rate estimates for most of the key constituents in the effluent stream (see Table 5-3) suggest that they are retained on the soil column. This is consistent with the conceptual model illustrated in Figure 4-19, showing iron, manganese, magnesium, and aluminum form metal-hydroxysilicates in the vadose zone beneath the backfill and the less mobile metal cations (lead, mercury, zinc, copper, and cadmium) form carbonates and hydroxides (see Figure 4-20). Chromium, sulfate, antimony, molybdenum, and selenium, on the other hand, would be expected to be flushed from the system based on the predicted migration rates (see Table $5-3$ ).

In summary, the predicted migration rates (see Table 5-3) are consistent with the geochemical conceptual model of the 100-D Ponds (section 4.5). However, additional soil column depth distribution data are needed to actually "calibrate" the one-dimension model used in this evaluation.

\subsection{EVALUATION OF MONITORING NETWORK ADEQUACY}

The RCRA monitoring program for the 100-D Ponds began in 1991 and is described by Hartman (1991). The four wells within the RCRA network wore sampled for the first time in 1992 (see Figure 4-18). The program has established baseline conditions for the network and is now in detection monitoring (DOE-RL 1993b).

Groundwater in the 100-D Area is al so being studied under the CERCLA program. The work for this program is covered by the 100-HR-3 Operable Unit. Twelve monitoring wells were installed for the CERCLA program in 1992 (see Figure 4-18).

\subsubsection{Groundwater Monitoring We11 Placement}

Four wells are sampled under the RCRA program for the 100-D Ponds. Additional wells are used to monitor water levels. Sampling began on the four RCRA wells in March and April of 1992. Table 5-4 lists the wells that are monitored for water levels and/or chemistry for the RCRA program. Figure 5-3 shows the well locations.

The RCRA Sampling network consists of one upgradient well (199-D5-13) and three downgradient wells. Two of the downgradient wells (199-D8-4 and -6) are adjacent to the pond. The remaining one (199-[8-5) is located farther from the facility, outside the ash mounds, and nearer the river. This well was 
located based on discussions with Ecology, to provide more information on river/aquifer interactions. Samples are collected from this well, but they are not statistically compared to the upgradient well (DOE-RL 1993b). The CERCLA Sampling network consists of 12 new wells supplemented by the RCRA wells and older wells (see Figure 5-3). These wells were installed in 1992 and are currently being sampled quarterly (DOE-RL 1992a).

\subsubsection{Reporting of Monitoring Data}

A11 hydrochemical monitoring data are reported in the HEIS database, which is publicly accessible. Monitoring results for the wells in 100-D Area for the period January 1990 through May 1993 are summarized in Tables 4-3 through 4-7 in the previous section.

The monitoring results are consistent with the proposed conceptual model for the 100-D Ponds, and well placement is adequate. 
WHC-EP-0666

5-6 
WHC-EP-0666

Figure 5-1. Lithology of Well 199-D8-3 Near 100-D Ponds (WHC 1990a).

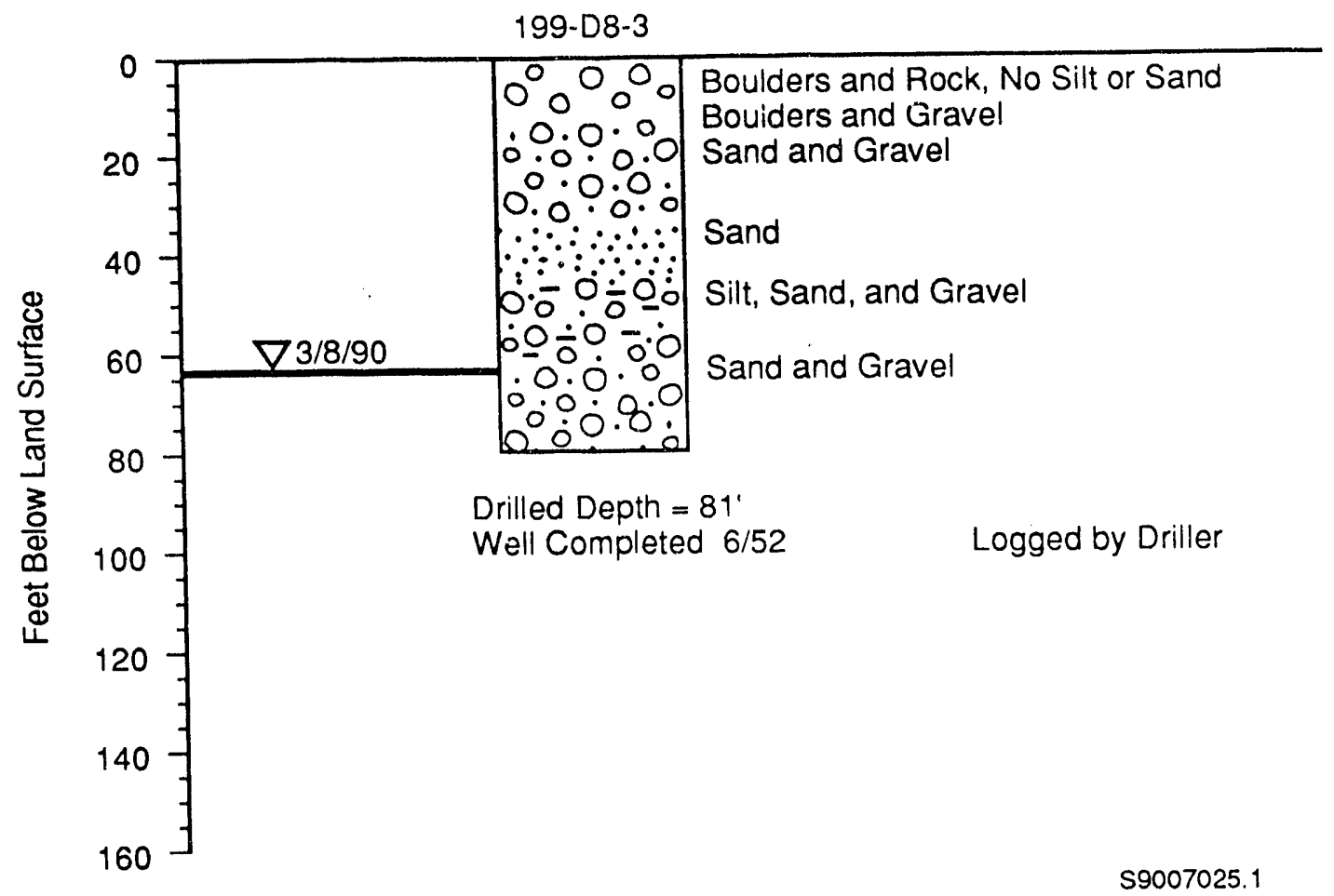


Figure 5-2. Hydraulic Conductivity Versus Moisture Content (WHC 1990a).

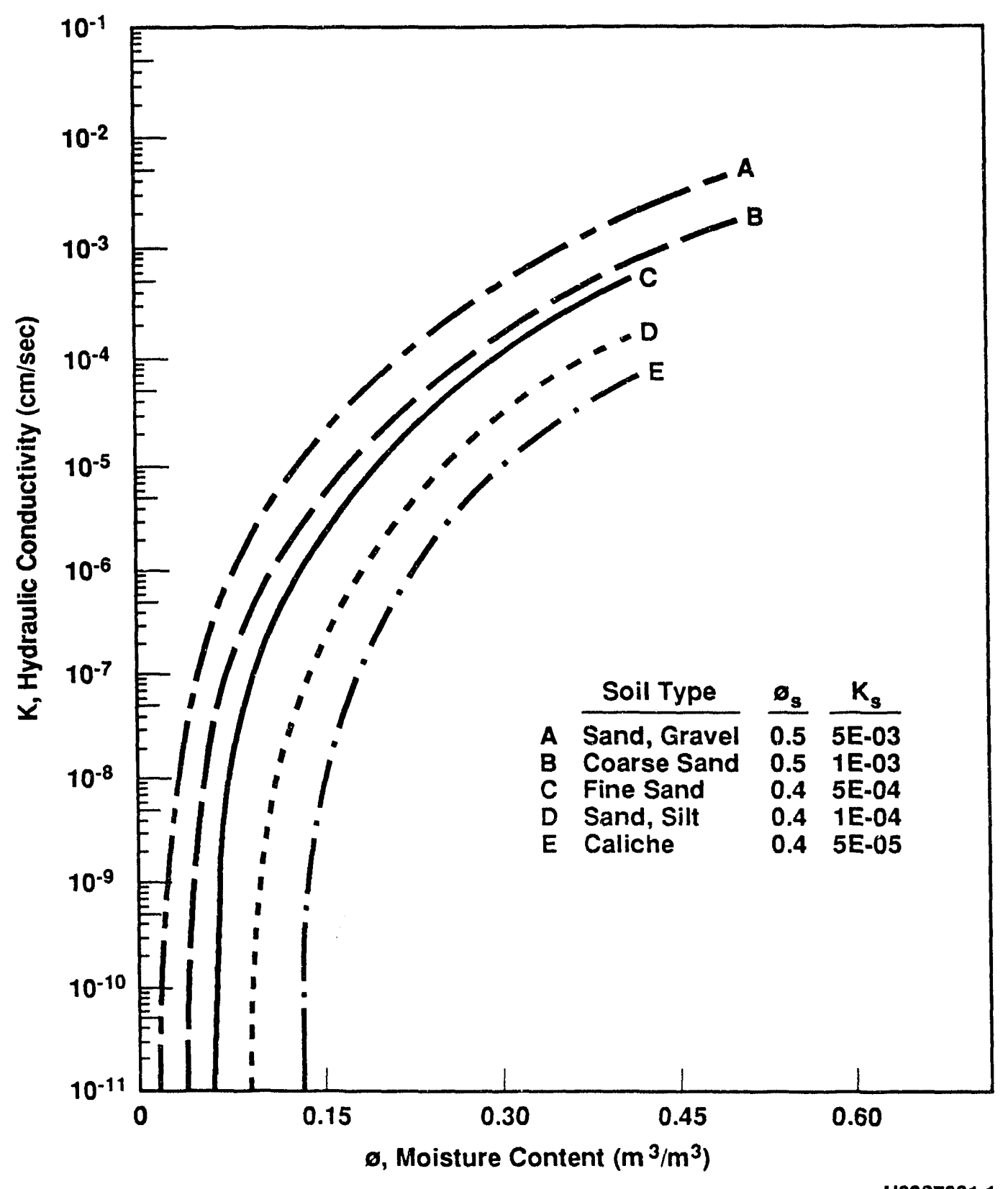


Figure 5-3. Groundwater Monitoring Wells in and near the 100-D Area (DOE-RL 1993b).

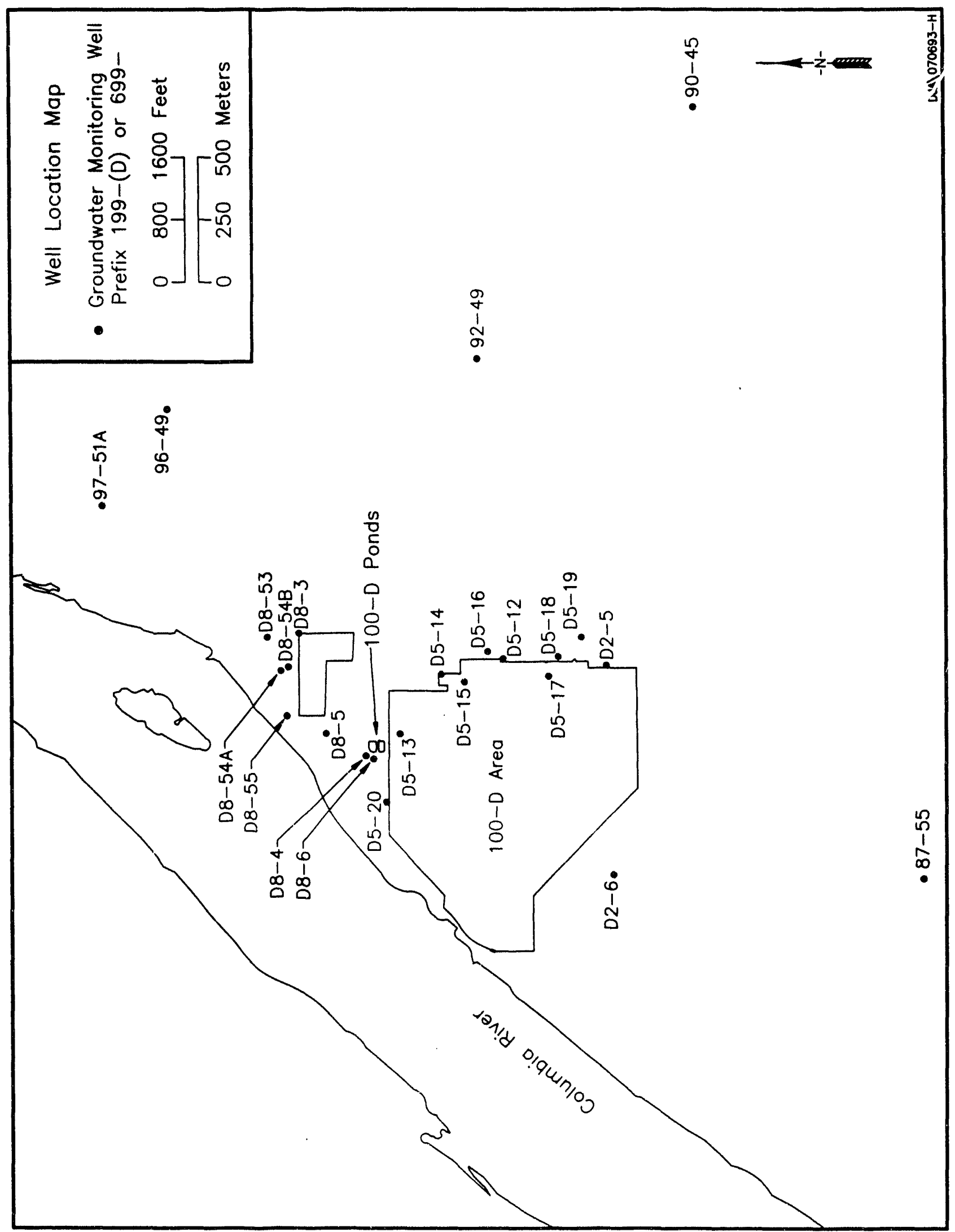


Table 5-1. Effluent Stream Sampling Data, 183-D Filter Backflush (WHC 1990a).

\begin{tabular}{|c|c|c|c|}
\hline $\begin{array}{c}\text { Key } \\
\text { constituents }\end{array}$ & $\begin{array}{l}\text { Detection } \\
\text { limit }\end{array}$ & $\begin{array}{l}\text { Detection/ } \\
\text { analyses }\end{array}$ & $\begin{array}{c}\text { Sample } \\
\text { concentration } 90 \% \\
\text { confidence } \\
\text { interval }\end{array}$ \\
\hline \multicolumn{4}{|c|}{ April 1987 to January 1988, During Routine Operation } \\
\hline Aluminum & NA & $4 / 4$ & 290,000 \\
\hline Chromium & 10 & $4 / 4$ & 220 \\
\hline Iron & 30 & $4 / 4$ & 32,000 \\
\hline Lead & 5 & $4 / 4$ & 120 \\
\hline Manganese & 5 & $4 / 4$ & 910 \\
\hline Mercury & 0.1 & $4 / 4$ & 10 \\
\hline Sulfate & 500 & $4 / 4$ & $1,500,000$ \\
\hline \multicolumn{4}{|c|}{ October 1989 to March 1990, During Routine Operation } \\
\hline Aluminum & NA & $4 / 4$ & 34,800 \\
\hline Chromium & 10 & $3 / 4$ & $17^{\mathrm{b}}$ \\
\hline Iron & 30 & $4 / 4$ & 3,930 \\
\hline Lead & 5 & $3 / 4$ & $13^{b}$ \\
\hline Manganese & 5 & $4 / 4$ & 120 \\
\hline Mercury & 0.1 & $4 / 4$ & $1^{b}$ \\
\hline Sulfate & 500 & $4 / 4$ & $19,000^{b}$ \\
\hline
\end{tabular}

anits: chemical--ppb, radionuclides--pCi/L.

'Concentration below Group A and C study' guidelines; value given for comparison purposes only.

$\mathrm{NA}=$ not available. 
Table 5-2. Initial Analytical Solution Results for the 100-D Ponds (WHC 1990a).

\begin{tabular}{|c|c|}
\hline $\begin{array}{l}\stackrel{0}{2} \\
\frac{2}{2} \\
i \frac{0}{\infty}\end{array}$ & $\ll$ \\
\hline 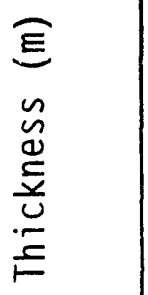 & ㅇ \\
\hline 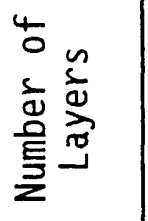 & $\rightarrow$ \\
\hline 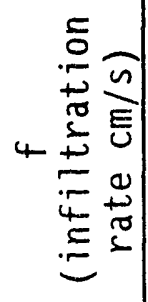 & $\begin{array}{l}\dddot{g} \\
1 \\
1 \\
m \\
\tilde{m} \\
\dot{m}\end{array}$ \\
\hline $\begin{array}{l}\widetilde{N} \\
\widetilde{E} \\
\tilde{D} \\
\dot{0} \\
\dot{0}\end{array}$ & $\stackrel{\text { ల్ }}{\infty}$ \\
\hline 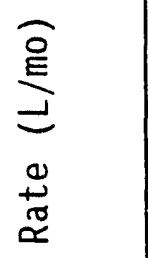 & 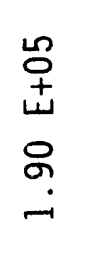 \\
\hline 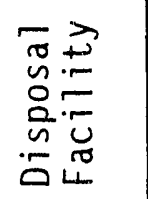 & $\begin{array}{l}0.4 \\
10 \\
8 \\
0\end{array}$ \\
\hline
\end{tabular}

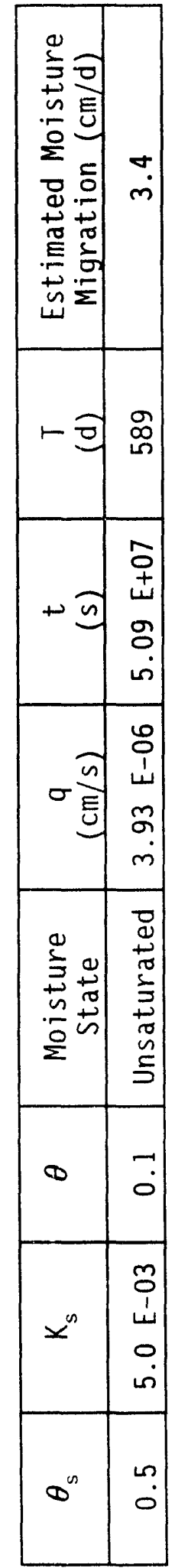

\begin{tabular}{|c|c|c|c|c|c|c|c|}
\hline 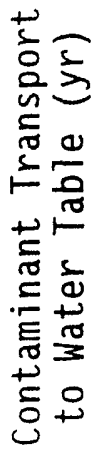 & $\sim$ & ஜ̊ & $\underset{\sim}{\sim}$ & ơ & $\underset{\sim}{\mathcal{~}}$ & $\sim$ & $\vec{\sigma}$ \\
\hline 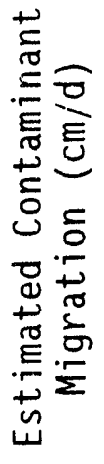 & $\begin{array}{l}\text { O } \\
\dot{m}\end{array}$ & $\overrightarrow{0}$ & $\begin{array}{l}\widetilde{O} \\
\dot{0}\end{array}$ & $\begin{array}{l}\overrightarrow{0} \\
\dot{0}\end{array}$ & $\begin{array}{l}\widetilde{0} \\
\text { ○े }\end{array}$ & $\begin{array}{l}\text { qे } \\
\dot{m}\end{array}$ & $\begin{array}{l}\text { o } \\
\dot{0}\end{array}$ \\
\hline 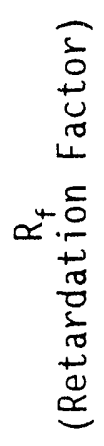 & $\rightarrow$ & $\stackrel{\circ}{\sim}$ & 욤 & $\stackrel{\circ}{\stackrel{2}{\sim}}$ & 욤 & $\rightarrow$ & 음 \\
\hline 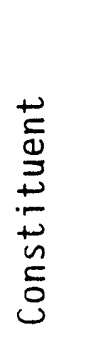 & 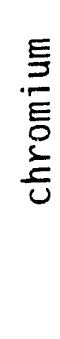 & 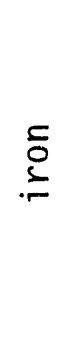 & 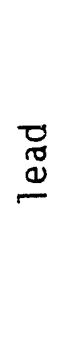 & 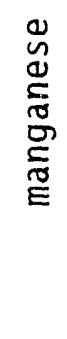 & 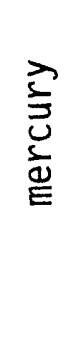 & 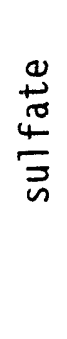 & 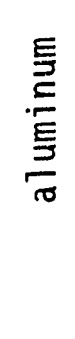 \\
\hline
\end{tabular}


Table 5-3. Revised Analytical Solution Results for the 100-D Ponds (adapted from WHC 1990a; input from Ames and Serne 1991).

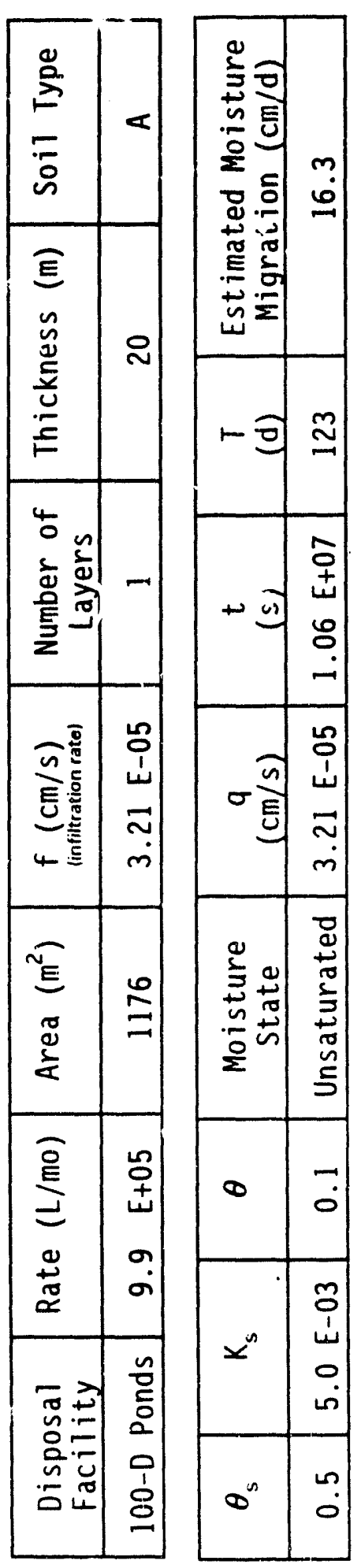

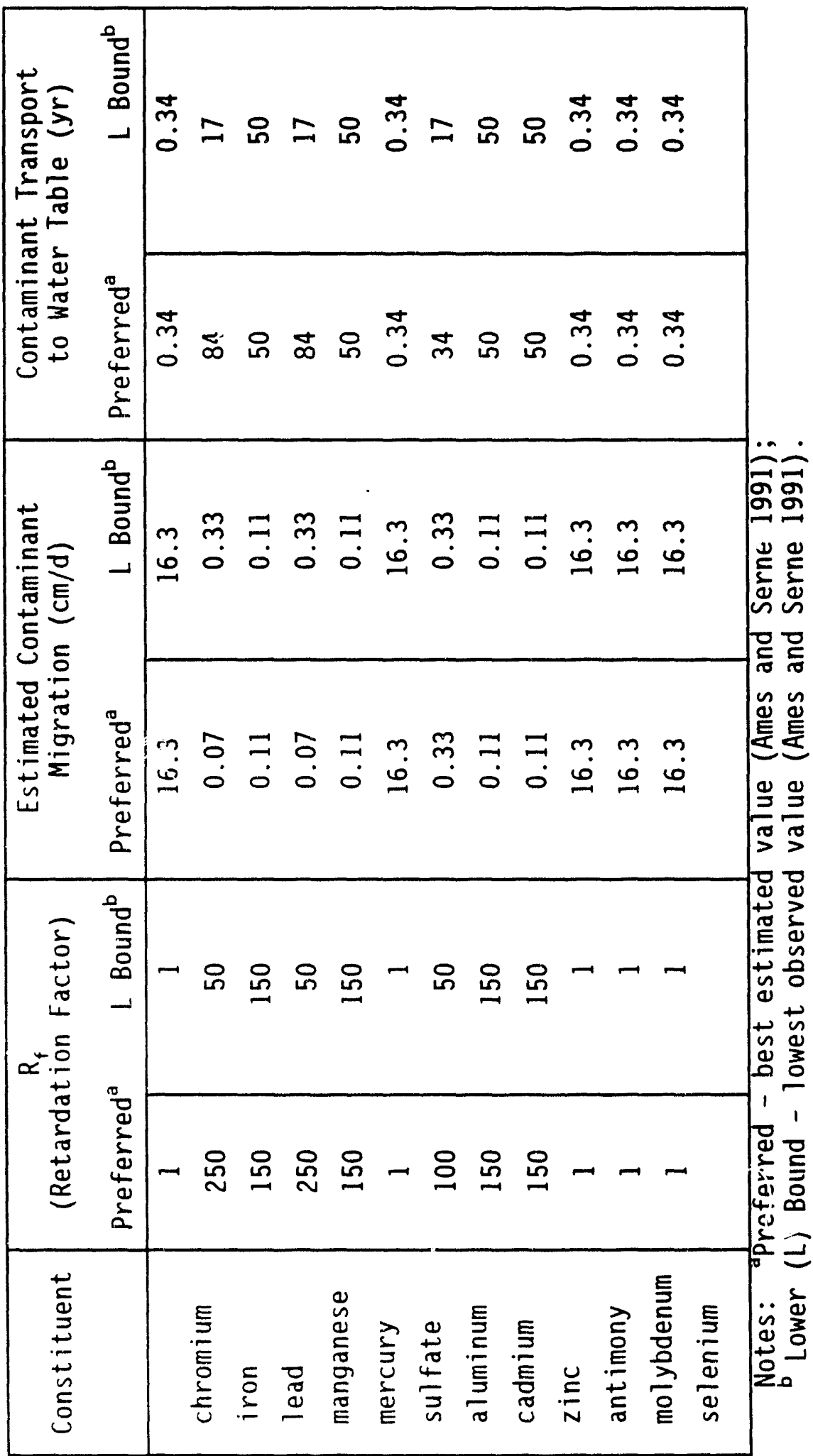


Table 3-4. Wells Monitored fur Chemistry or Water Levels for the 100-D Ponds (DOE-RL 1993b).

\begin{tabular}{|c|c|c|c|c|c|}
\hline $\mathrm{We} 11^{\mathrm{a}}$ & Aquifer & $\begin{array}{c}\text { RCRA } \\
\text { Sampling } \\
\text { Frequency }\end{array}$ & $\begin{array}{l}\text { Water } \\
\text { Levels }\end{array}$ & $\begin{array}{c}\text { Well } \\
\text { Standard } \\
\text { s }\end{array}$ & $\begin{array}{c}\text { Other } \\
\text { Networks }\end{array}$ \\
\hline $199-02-5^{60}$ & Top of unconfined & $\overline{--}$ & $M$ & NON & $100-H R-3$ \\
\hline $199-02-6^{92}$ & Top of unconfined & -- & $M$ & RCRA & $100-H R-3$ \\
\hline $199-D 5-12^{60}$ & Top of unconfined & -- & $M$ & NON & $100-H R-3$ \\
\hline $199-D 5-13^{91} U$ & Top of unconfined & $Q$ & $\bar{M}$ & RCRA & $100-H R-3$ \\
\hline $199-05-14^{92}$ & Top of unconfined & -- & $M$ & RCRA & $100-H R-3$ \\
\hline $199-05-15^{92}$ & Top of unconfined & -- & M & RCRA & $100-H R-3$ \\
\hline $199-D 5-16^{92}$ & Top of unconfined & -- & $M$ & RCRA & $100-H R-3$ \\
\hline $199-05-17^{92}$ & Top of unconfined & -- & M & RCRA & $100-H R-3$ \\
\hline $199-05-18^{92}$ & Top of unconfined & -- & M & RCRA & $100-H R-3$ \\
\hline $199-D 5-19^{92}$ & Top of unconfined & -- & M & RCRA & $100-H R-3$ \\
\hline $199-D 5-20^{92}$ & Top of unconfined & - & $\bar{M}$ & RCRA & $100-H R-3$ \\
\hline $199-D 8-3^{52}$ & Top of unconfined & -- & M & NON & $100-H R-3$ \\
\hline $199-D 8-4^{91 b}$ & Top of unconfined & $Q$ & $M$ & RCRA & $100-H R-3$ \\
\hline $199-D 8-5^{91}$ & Top of unconfined & Q & $M$ & RCRA & $100-H R-3$ \\
\hline $199-D 8-6^{91}$ & Top of unconfined & Q & $M$ & RCRA & $100-H R-3$ \\
\hline $199-08-53^{92}$ & Top of unconfined & -- & $\bar{M}$ & RCRA & $100-H R-3$ \\
\hline $199-D 8-54 A^{92}$ & Top of unconfined & -- & M & RCRA & $100-H R-3$ \\
\hline $199-D 8-54 B^{92}$ & Top of unconfined & -- & M & RCRA & $100-H R-3$ \\
\hline $199-D 8-55^{92}$ & Top of unconfined & -- & $\bar{M}$ & RCRA & $100-H R-3$ \\
\hline $699-87-55^{c}$ & Top of unconfined & -- & $M$ & NON & -- \\
\hline $699-90-45^{c}$ & Top of unconfined & -- & $M$ & NON & -- \\
\hline $699-92-49^{c}$ & Top of unconfined & -- & $M$ & NON & -- \\
\hline $699-96-49^{62}$ & Top of unconfined & -- & $M$ & NON & $100-H R-3$ \\
\hline $699-97-51 A^{c}$ & Top of unconfined & -- & $M$ & NON & $100-H R-3$ \\
\hline
\end{tabular}

a superscript number following well number denotes year of installation.

Well 199-D8-5 will not be used for detection purposes per agreement with Ecology.

CThe year of the well completion is unknown.

$M$ = frequency on a monthly bas is.

NON = well was not constructed to RCRA standards.

$Q \quad=$ frequency on a quarterly basis.

RCRA = well is in compl iance with RCRA standards.

$U$ = upgradient well in sampling network. 
WHC-EP-0666

5-14 


\subsection{SUMMARY AND CONCLUSIONS}

Based on current effluent conditions, continued operation of the 100-D Ponds will not adversely affect groundwater quality in the 100-D area. The ponds are contributing to a slightly elevated $\mathrm{pH}$ in the wells nearest to and immediately downgradient of the pond. This can be attributed to pond construction within the old coal ash disposal basin. The pond sediment TCLP data exhibit slightly elevated concentrations of chromium, cadmium, and lead, but they do not exceed the WWQS. The coal ash may be contributing cationic metals to the soil column further beneath the ponds, but due to the slightly alkaline $\mathrm{pH}$, there is no evidence of elevated concentrations of metals in solution in the groundwater samples from near the pond. It appears that the bulk of the leachable metals have already been removed from the system.

Metals that might remain in the pond sediment and the soil column beneath the pond are likely retained by the slightly alkaline $\mathrm{pH} /$ carbonate "geochemical trap" illustrated in Figure 4-19. The conceptual model for this "geochemical trap" should be evaluated using actual soil column depth distribution data.

The pond effluent water dilutes the groundwater in the immediate vicinity. This effect is most prominent in the wells nearest the pond but can be seen downgradient of the ponds in a few wells. Water elevations in monitoring wells near the ponds respond slightly to discharges. However, the hydraulic influence on local groundwater flow patterns is minor. The groundwater monitoring well network for this site is adequate. 
WHC-EP-0666 


\subsection{REFERENCES}

Ames, L. L., and R. J. Serne, 1991, Compilation of Data to Estimate Groundwater Migration Potential for Constituents in Active Liquid Discharges at the Hanford Site, PNL-7660, Pacific Northwest Laboratory, Richland, Washington.

Baker, V. R., B. N. Bjornstad, A. J. Busacca, K. R. Fecht, E. P. Kiver, U. L. Moody, J. G. Rigby, D. F. Stradling, and A. M. Tallman, 1991, "Quaternary Geology of the Columbia Plateau," in Quaternary Nonglacial Geology; Conterminous United States, R.B. Morrison (editor), Geological Society of America, The Geology of North America, v. K-2, p. 215-250, Boulder, Colorado.

Bjornstad, B. N., 1984, Suprabasalt Stratigraphy Within and Adjacent to the Reference Repository Location, SD-BWI-DP-039, Rockwe11 Hanford Operations, Richland, Washington.

Black, R. F., 1979, Clastic Dikes of the Pasco Basin, Southeastern Washington, RHO-BWI-C-64, Rockwell Hanford Operations, Richland, Washington.

Bouwer, H., 1978, Ground Water Hydrology, McGraw Hill, New York, New York.

Campbe11, N. P., 1989, "Structural and Stratigraphic Interpretation of Rocks Under the Yakima Fold Belt, Columbia Basin, Based on Recent Surface Mapping and Well Data," in Volcanism and Tectonism in the Columbia Flood-Basalt Province, Special Paper 239, edited by S.P. Reidel and P.R. Hooper, Geological Society of America, Boulder, Colorado, p. 209-222.

Cushing, C.E. (ed.), 1989, Hanford Site National Environmental Policy Act (NEPA) Characterization, PNL-6415, prepared by Pacific Northwest Laboratory for the U.S. Department of Energy, Richland, Washington.

Delaney, C. D., K. A. Lindsey, and S. P. Reidel, 1991, Geology and Hydrology of the Hanford Site: A Standardized Text for use in Westinghouse Hanford Company Documents and Reports, WHC-SD-ER-TI-003, Rev. 0, Westinghouse Hanford Company, Richland, Washington.

DOE, 1987, Final Environmental Impact Statement--Disposal of Hanford Defense High-Level, Transuranic and Tank Wastes, Vols. 1 to 5, DOE/EIS-0113, U.S. Department of Energy, Washington, D.C.

DOE, 1988, Site Cliaracterization Plan, Reference Repository Location, Hanford Site, Washing:on, Consultation Draft, DOE/RW-0164, U.S. Department of Energy, Washington, D.C.

DOE-RL, 1990, Remedial Investigation/ Feasibility Study Work Plan for the 300-FF-5 Operable Unit, Hanford Site, Richland, Washington, DOE/RL 89-14, Richland, Washington. 
DOE-RL, 1992a, RCRA Facility Investigation/Corrective Measures Study Work Plan for the 100-HR-3 Operable Unit, Hanford Site, Richland, Washington, DOE/RL 88-36, Rev. 0, U. S. Department of Energy, Richland Operations Office, Richland, Washington.

DOE-RL, 1992b, RCRA Facility Investigation/Corrective Measures Study Work Plan for the 100-DR-1 Operable Unit, Hanford Site, Richland, Washington, DOE/RL 89-09, Rev. 0, U.S. Department of Energy, Richland Operations Office, Richland, Washington.

DOE-RL, 1992C, Long-Term Storage and Disposal of Coal-Fired Steam Plant Ash on the Hanford Site, DOE/RL 92-RPB-192, U.S. Department of Energy, Richland Operations Office, Richland, Washington.

DOE-RL, 1992d, Hanford Site Groundwater Background, DOE/RL 92-23, U.S. Department of Energy, Richland Operations Office, Richland, Washington.

DOE-RL, 1993a, 100-D Ponds Closure P7an, DOE/RL 92-71, Rev. 0, U.S. Department of Energy, Richland Operations Office, Richland, Washington.

DOE-RL, 1993b, Annual Report for RCRA Groundwater Monitoring Projects at i.anford Site Facilities for 1992, DOE/RL-93-09, Rev. 0, UC-702, U.S. Department of Energy, Richland Operations Office, Richland, Washington.

Dorian, J. J. and V. R. Richards, 1978, Radiological Characterization of the Retired 100 Areas, UNI-946, United Nuclear Industries, Inc., Richland, Washington.

Ecology, EPA, DOE-RL, 1991, Hanford Federal Facility Agreement and Consent order, Second amendment, Two volumes, 89-10 Revision 2, Washington Department of Ecology, Olympia, Washington, U.S. Environmental Protection Agency, Region X, Seattle, Washington, and U.S. Department of Energy, Richland Operations Office, Richland, Washington.

ERDA, 1975, Final Environmental Impact Statement on Waste Management Operations, Hanford Reservation, Energy Research and Development Administration, ERDA-1538, 2 volumes, Washington, D.C.

Fecht, K. R., S. P. Reidel, and A. M. Tallman, 1987, Paleodrainage of the Columbia River System on the Columbia Plateau of Washington State-a Summary, in Selected Papers on the Geology of Washington, Division of Geology and Earth Resources, Bulletin 77, p. 219-248, edited by J. E. Schuster.

Gee, G. W., 1987, Recharge of the Hanford Site: Status Report, PNL-6403, Pacific Northwest Laboratory, Richland, Washington.

Gephart, R.E., R. C. Arnett, R. G. Baca, L.S. Leonhard, and F. A. Spane, Jr., 1979, Hydrologic Studies within the Columbia Plateau, Washington: An Integration of Current Knowledge, RHO-BWI-ST-5, Rockwell Hanford Operations, Richland, Washington. 
Graham, M. J., M. D. Hal1, S. R. Strait, and W. R. Brown, 1981, Hydrology of the Separations Area, RHO-ST-42, Rockwell Hanford Operations, Richland, Washington.

Graham, M. J., G. V. Last, and K. R. Fecht, 1984, An Assessment of Aquifer Intercommunication in the $B$ Pond-Gable Mountain Pond Area of the Hanford Site, RH0-RE-ST-12, Rockwel1 Hanford Operations, Richland, Washington.

Hartman, M. J., 1991, Groundwater Monitoring Plan for the 100-D Ponds, WHC-SD-EN-048, Rev. 0, Westinghouse Hanford Company, Richland, Washington.

Hartman, M. J., 1992, Borehole Completion Data Package for the 100-D Ponds: Cr 1992, WHC-SD-EN-DP-043, Rev. 0, Westinghouse Hanford Company, Richland, Washington.

Hartman, M. J. and R. E. Peterson, 1992, Hydrologic Information Summary for the Northern Hanford Site, Washington, WHC-SD-EN-TI-023, Westinghouse Hanford Company, Richland, Washington.

Herman, D. R., 1992, Sampling and Analysis Plan for the 183-D Area Filter Backwash Facility Process Wastewater, WHC-SD-WM-PLN-035, Rev. 2, Westinghouse Hanford Company, Richland, Washington.

Johnson, V. G., 1993, Westinghouse Hanford Company Operational Groundwater Status Report, WHC-EP-0595/UC-712, Westinghouse Hanford Company, Richland, Washington.

Last, G. V., B. N. Bjornstad, M. P. Bergeron, R. W. Wallace, D. R. Newcomer, J. A. Schramke, M. A. Chamness, C. S. Cline, S. P. Airhart, and J. S. Wilbur, 1989, Hydrogeology of the 200 Areas Low-Level Burial Grounds -- An Interim Report, PNL-6820, Pacific Northwest Laboratory, Richland, Washington.

Liikala, T.L., R.L. Aaberg, N.J. Aimo, D.J. Bates, et al, 1988, Geohydrologic Characterization of the Area Surrounding the 183-H Solar Evaporation Basins, PNL-6728, Pacific Northwest Laboratory, Richland, Washington.

Lindberg, J.W. and F.W. Bond, 1979, Geohydrology and Groundwater Quality Beneath the 300 Area, Hanford Site, Washington, PNL-2949, Pacific Northwest Laboratory, Richland, Washington.

Lindsey, K. A., 1991a, Revised Stratigraphy for the Ringold Formation, Hanford Site, South-Central Washington, WHC-SD-EN-EE-004 Rev. 0, Westinghouse Hanford Company, Richland, Washington.

Lindsey, K. A., 1991b, Sedimentation and Basin Evolution of the Late Neogene Ringold Formation, Central Columbia Plateau, South-Central Washington, Geological Society of America Abstracts with Programs, v. 23, no. 5, p. A285, Boulder, Colorado.

Lindsey, K. A., 1992, Geology of the Northern Part of the Hanford Site: An Outline of Data Sources and the Geologic Setting of the 100 Areas, WHC-SD-EN-TI-011, Westinghouse Hanford Company, Richland, Washington. 
Lindsey, K. A., M. P. Connelly, and B. N. Bjornstad, 1991, Geologic Setting of the 200 West Area: An Update, WHC-SD-EN-TI-008, Westinghouse Hanford Company, Richland, Washington.

Lindsey, K. A. and G. K. Jaeger, 1993, Geologic Setting of the 100-HR-3 Operable Unit, Hanford Site, South-Central Washington, WHC-SD-EN-TI-132, Rev. 0, Westinghouse Hanford Company, Richland, Washington.

McCarthy, G. J., and G. H. Groenewold, 1983, Unpublished Paper on North Dakota Power Plant Solid Waste Characterization, North Dakota State University, Fargo, North Dakuta, and University of North Dakota, Grand Forks, North Dakota.

Myers, C. W., S. M. Price, J. A. Caggiano, M. P. Cochran, W. J. Czimer, N. J. Davidson, R. C. Edwards, K. R. Fecht, G. E. Holmes, M. G. Jones, J. R. Kunk, R. D. Landon, R. K. Ledgerwood, J. T. Li11 ie, P. E. Long, T. H. Mitche11, E. H. Price, S. P. Reide1, and A. M. Tallman, 1979, Geologic Studies of the Columbia Plateau: A Status Report, RHO-BWI-ST-4, Rockwel1 Hanford Operations, Richland, Washington.

Price, S. M., 1989, Metallic Mercury Discovered at 189-D, (internal memo 80252-89-113 to K. A. Gano, October 16), Westinghouse Hanford Company, Richland, Washington.

PSPL, 1982, Skagit/Hanford Nuclear Project, Preliminary Safety Analysis Report, Vol. 4, App. 20, Amendment 23, Puget Sound Power and Light Company, Bellevue, Washington.

Rasmussen, 0. R. and R. A. Carlson, 1987, Design Specifications for the Semiworks (201-C) Site Engineered Barrier, WHC-SD-DD-TI-004, Westinghouse Hanford Company, Richland, Washington.

Reidel, S. P., 1984, The Saddle Mountains: The Evolution of an Anticline in the Yakima Be7t, American Journal Of Science, v. 284, p. 942-978.

Reidel, S. P., and K. R. Fecht, 1981, Wanapum and Saddle Mountains Basalt in the Cold Creek Syncline Area, in Subsurface Geology of the Cold Creek Syncl ine, RHO-BWI-ST-14, Rockwell Hanford Operations, Richland, Washington.

Reidel, S. P. and P. R. Hooper, 1989, editors, Volcanism and Tectonism in the Columbia River Flood-Basalt Province, Special Paper 239, Geological Society of America, Boulder, Colorado, $386 \mathrm{p}$.

Reide1, S. P., K. R. Fecht, M. C. Hagood, and T. L. Tolan, 1989, "The Geologic Evolution of the Central Columbia Plateau," in Volcanism and Tectonism in the Columbia River Flood-Basalt Province, Special Paper 239, edited by S. P. Reidel and P. R. Hooper, Geological Society of America, Boulder, Colorado, p. 247-264.

Reide1, S. P., K. A. Lindsey, and K. R. Fecht, 1992, Field Trip Guide to the Hanford Site, WHC-MR-0391, Westinghouse Hanford Company, Richland, Washington. 
Richman, R. B., 1956, Preliminary Evaluation of Separan 2610 for Process Water Treatment, HW-44110, General Electric Hanford Atomic Products Operation, Richland, Washington.

Rockhold, M. L., M. J. Fayer, G. W. Gee, and M. J. Kanyid, 1990, Natural Groundwater Recharge and Water Balance at the Hanford Site, PNL-7215, Pacific Northwest Laboratory, Richland, Washington.

Routson, R. C. and V. G. Johnson, 1990, "Recharge Estimates for the Hanford Site 200 Areas Piateau," Northwest Science, v. 64, no. 3.

Rubin, A. J., 1974, Aqueous-Environmental Chemistry of Metals, Ann Arbor Science Publishers Inc., Ann Arbor, Michigan.

Serkowski, J. A., and W. A. Jordan, 1989, Operational Groundwater Monitoring at the Hanford Site--1988, WHC-EP-0260, Westinghouse Hanford Company, Richland, Washington.

Smith, G. A., 1988, "Neogene Synvolcanic and Syntectonic Sedimentation in Central Washington," v. 100, p. 1479-1492, Geological Society of America Bulletin, Boulder, Colorado.

Smith, G. A., B. N. Bjornstad, and K. R. Fecht, 1989, "Neogene Terrestrial Sedimentation on and Adjacent to the Columbia Plateau; Washington, Oregon, and Idaho," in Volcanism and Tectonism in the Columbia River Flood-Basalt Province, Special Paper 239, edited by S. P. Reidel and P. R. Hooper, Geological Society of America, Boulder, Colorado, p. 187-198.

Stordeur, R. T. and D. L. Flyckt, 1988, Annual Status Report of the Plan and Schedule to Discontinue Disposal of Contaminated Liquids into the Soil Column at the Hanford Site, WHC-EP-0196-1, Westinghouse Hanford Company, Richland, Washington.

Tallman, A. M., K. R. Fecht, M. C. Marratt, and G. V. Last, 1979, Geology of the Separations Areas, Hanford Site, South-Central Washington, RHO-ST-23, Rockwe 11 Hanford Operations, Richland, Washington.

Tallman, A. M., J. T. Lillie, and K. R. Fecht, 1981, "Suprabasalt Sediments of the Cold Creek Syncline Area," in Subsurface Geology of the Cold Creek Syncline, RHO-BWI-ST-14, C. W. Myers, and S. M. Price, Rockwell Hanford Operations, Richland, Washington.

Tolan, T. L. and S. P. Reidel, 1989, "Structure Map of a Portion of the Columbia River Flood-Basait Province," in Volcanism and Tectonism in the Columbia River Flood-Basalt Province, Special Paper 239, edited by S. P. Reidel and P. R. Hooper, Geological Society of America, Boulder, Colorado, plate 1 .

Tolan, T. L., S. P. Reidel, M. H. Beeson, J. L. Anderson, K. R. Fecht, and D. A. Swanson, 1989, "Revisions to the Extent and Volume of the Columbia River Basalt Group," in Volcanism and Tectonism in the Columbia River Flood-Basalt Province, Special Paper 239, edited by S. P. Reidel and P. R. Hooper, Geological Society of America, Boulder, Colorado, p. 1-20. 
Tyler, D. K., 1991, A Methodology for Assessing Impacts to Groundwater from Disposal of Liquid Effluent to the Soil at the Hanford Site, WHC-SD-EN-EV-008, Rev. 0, Westinghouse Hanford Company, Richland, Washington.

WHC, 1989, Waste Stream Characterization Report, WHC-EP-0287, Vo1. 3, Westinghouse Hanford Company, Richland, Washington.

WHC, 1990a, Liquid Effluent Study Final Project Report, WHC-EP-0367, Westinghouse Hanford Company, Richland, Washington.

WHC, 1990b, Liquid Effluent Study: Ground Water Characterization Data, WHC-EP-0366, Westinghouse Hanford Company, Richland, Washington.

WHC, 1990c, 183-D Filter Backwash Wastewater Stream-Specific Report, WHC-EP-0342, Addendum 33, Westinghouse Hanford Company, Richland, Washington.

Wilson, D. W., 1990, Designation of 284 E Powerhouse Flyash, WHC Internal Memo No. 82841-90-033, dated May 2, 1990, Westinghouse Hanford Company, Richland, Washington. 


\section{DISTRIBUTION}

Number of copies

QFFSITE

1

2

2

2

1

26

6
Southwest Research Institute

B. Sagar

6220 Culebra Road

San Antonio, Texas 78284

Confederated Tribes of the Umatilla Reservation

J. R. Wilkinson

P.0. Box 638

Pendleton, OR 97801

Nez Perce Tribal Office

D. Powaukee

P. 0. Box 305

LaPwai, ID 83540

Yakima Indian Nation

R. F. Cook

2552 Haines

Richland, WA 99352

ONSITE

U.S. Department of Energy

K. V. Clarke

A5-15

M. J. Furman

R3-81

J. M. Hennig

R3-80

J. E. Rasmussen

S. H. Wisness

A5-15

A5-15

RL Public Reading Room

Al-65

Pacific Northwest Laboratory

PNL Technical Files

$\mathrm{K} 1-11$

Westinghouse Hanford Company

D. J. Alexander (5)

L. E. Borneman

H6-06

B. A. Davis

B2-35

K. R. Fecht

B. H. Ford

M. J. Hartman

R3-82

H6-06

H6-06

D. R. Herman

H6-06

M. P. Johansen

A5-19 


\section{DISTRIBUTION (cont.)}

\section{Number of copies}

\section{ONSITE}

Westinghouse Hanford Company (cont.)

\begin{tabular}{|c|c|}
\hline $\begin{array}{l}\text { V. G. Johnson } \\
\text { D. E. Kelley } \\
\text { A. J. Knepp } \\
\text { K. A. Lindsey } \\
\text { R. E. Peterson } \\
\text { S. P. Reidel } \\
\text { K. M. Singleton } \\
\text { D. R. Speer } \\
\text { D. K. Tyler } \\
\text { Central Files } \\
\text { Document Processing } \\
\text { and Distribution (2) } \\
\text { Environmental Data } \\
\text { Management Center } \\
\text { Information Release } \\
\text { Administration }\end{array}$ & $\begin{array}{l}\text { H6-06 } \\
\text { R3-46 } \\
H 6-06 \\
H 6-06 \\
H 6-06 \\
H 6-06 \\
H 6-06 \\
\text { R1-48 } \\
H 6-06 \\
\text { L8-04 } \\
\text { L8-15 }\end{array}$ \\
\hline
\end{tabular}



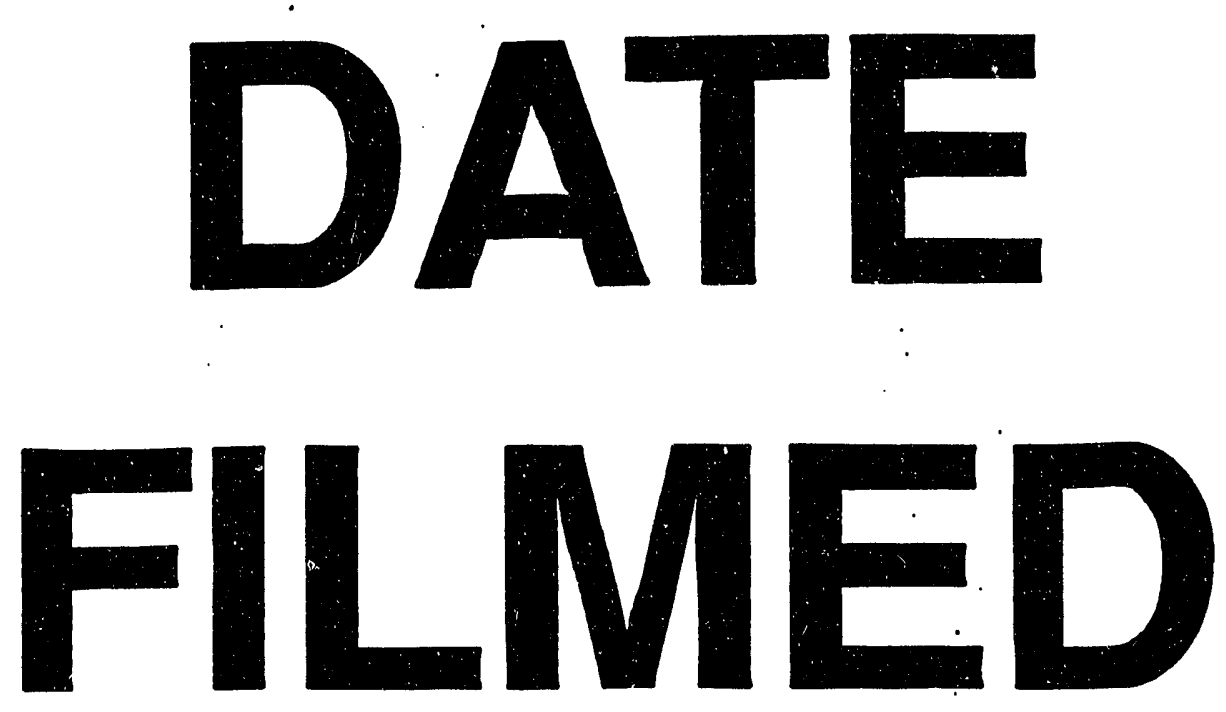

$11 / 4 / 93$
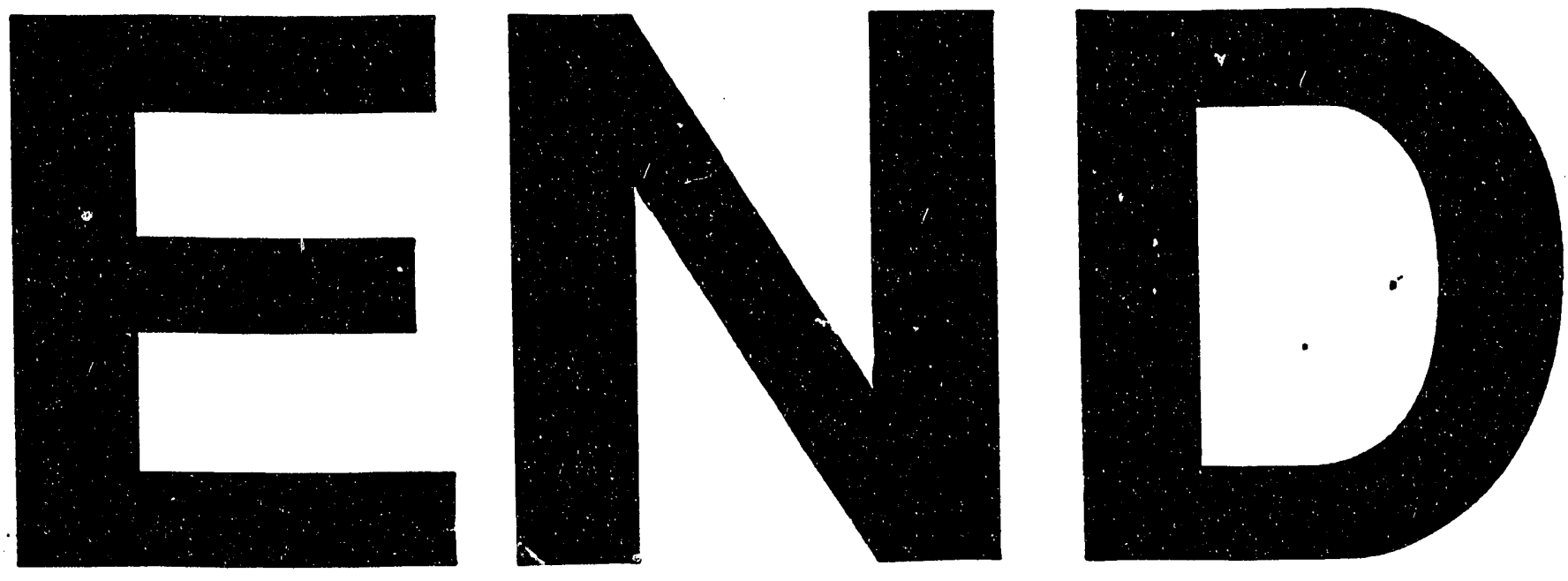